by Hillebrandt, A.v. ${ }^{l}$, Krystyn, L. ${ }^{2}$, Kürschner, W.M. ${ }^{3}$, Bonis, N.R. ${ }^{4}$, Ruhl, M. ${ }^{5}$, Richoz, S. ${ }^{6}$, Schobben, M. A. N. ${ }^{12}$, Urlichs, M. ${ }^{7}$, Bown, P.R. ${ }^{8}$, Kment, K. ${ }^{9}$, McRoberts, C.A. ${ }^{10}$, Simms, M. ${ }^{11}$, and Tomãsových, $A^{13}$

\title{
The Global Stratotype Sections and Point (GSSP) for the base of the Jurassic System at Kuhjoch (Karwendel Mountains, Northern Calcareous Alps, Tyrol, Austria)
}

\author{
1 Institut für Angewandte Geowissenschaften, Technische Universität, Ernst-Reuter-Platz 1, 10587 Berlin, Germany. \\ E-mail: axel.vonhillebrandt@campus.tu-berlin.de \\ 2 Department for Palaeontology, Vienna University, Geozentrum, Althansstr. 9, A-1090 Vienna, Austria. E-mail: leopold.krystyn@ univie.ac.at \\ 3 Department of Geosciences and Centre of Earth Evolution and Dynamics (CEED), University of Oslo, PO box 1047, Blindern, 0316 Oslo, \\ Norway.E-mail:w.m.kuerschner@geo.uio.no \\ 4 Shell Global Solutions International B.V., Kessler Park 1, 2288 GS, Rijswijk, the Netherlands. E-mail: nina.bonis@ shell.com \\ 5 Department of Earth Sciences, University of Oxford, South Parks Road, Oxford OX13AN, UK. E-mail: micha.ruhl@earth.ox.ac.uk \\ 6 Commission for the Palaeontological and Stratigraphical Research of Austria, Austrian Academy of Sciences c/o Institut of Earth Sciences, \\ Graz University, Heinrichstraße 26, 8010 Graz, Austria. E-mail: sylvain.richoz@uni-graz.at \\ 7 Staatliches Museum für Naturkunde, Rosenstein 1, 70191 Stuttgart, Germany. E-mail: max.urlichs@smns-bw.de \\ 8 Department of Earth Sciences, University College London, Gower Street, London WC1E 6BT, UK. E-mail: p.bown@ucl.ac.uk \\ 9 Lenggrieser Str. 52, 83646 Bad Tölz, Germany.E-mail: kurt.kment@moralt-tischlerplatten.de \\ 10 Department of Geology, State University of New York at Cortland, P.O. Box 2000, Cortland, New York 13045, USA. \\ E-mail: mcroberts@cortland.edu \\ 11 Ulster Museum, Botanic Gardens, Belfast BT9 5AB, UK.E-mail: michael.simms@magni.org.uk \\ 12 Museum für Naturkunde, Berlin, Invalidenstrasse 43, 10115 Berlin, Germany. E-mail: martin.schobben@mfn-berlin.de \\ 13 Geological Institute Slovak Academy of Science, Dubravska cesta 9, Bratislava, 84005, Slovakia. E-mail: geoltoma@savba.sk
}

The Global Stratotype Section and Point (GSSP) defining the base of the Jurassic System Lower Jurassic Epoch and Hettangian Stage is situated at the Kuhjoch pass, Karwendel Mountains, Northern Calcareous Alps, Austria $\left(47^{\circ} 29^{\prime} 02^{\prime \prime} \mathrm{N} / 11^{\circ} 31^{\prime} 50^{\prime \prime} \mathrm{E}\right)$. The Triassic-Jurassic (T-J) boundary is exposed at Kuhjoch West and at Kuhjoch East, and corresponds to the first occurrence $(F O)$ of the ammonite Psiloceras spelae tirolicum. The "Golden Spike" was fixed at Kuhjoch East. The section displays a high and continuous sedimentation rate with a constant facies trend across the boundary level. Other bio-events include the FO of the aragonitic foraminifer Praegubkinella turgescens, and of diverse ostracod species 1.0-3.40 cm below the FO of P. spelae and $3.2 \mathrm{~m}$ below P. spelae occurs the continental palynomorph Cerebropollenites thiergartii. Because of the lack of other terrestrial microfloral events this is yet the FO event closest to the FO of $\mathrm{P}$. spelae and allows a correlation with nonmarine sediments. The $\delta^{13} C_{\text {org }}$ record shows a strong initial negative excursion at the boundary between the Kössen and Kendlbach formations, $5.8 \mathrm{~m}$ (Kuhjoch W) below the T-J boundary, a shift to more positive $\delta^{13} C_{\text {org }}$ in the Schattwald Beds and a gradual decline to more negative values at the transition of the Schattwald Beds to the proximate Tiefengraben $\mathrm{M} b$. The stratotype point lies within a zone of smaller negative and positive $\delta^{13} C_{\text {org }}$ peaks, which is superimposed on a longer lasting main negative shift. According to recent investigations, the radiometric age of the T-J boundary is about 201,3 Ma.

\section{Introduction}

The Global Stratotype Section and Point (GSSP) defining the base of the Jurassic System, Lower Jurassic Series and Hettangian Stage is situated at the Kuhjoch pass, Karwendel Mountains, Tyrol, Austria $\left(47^{\circ} 29^{\prime} 02^{\prime \prime N} / 11^{\circ} 31^{\prime} 50 " \mathrm{E}\right)$ (Figs. 1-4). This boundary has recently been defined by decisions of the International Subcommission on Jurassic Stratigraphy (ISJS) in June 2008, by the International Commission on Stratigraphy (ICS) in May 2009 and ratified by the Executive Committee of the International Union of Geosciences 


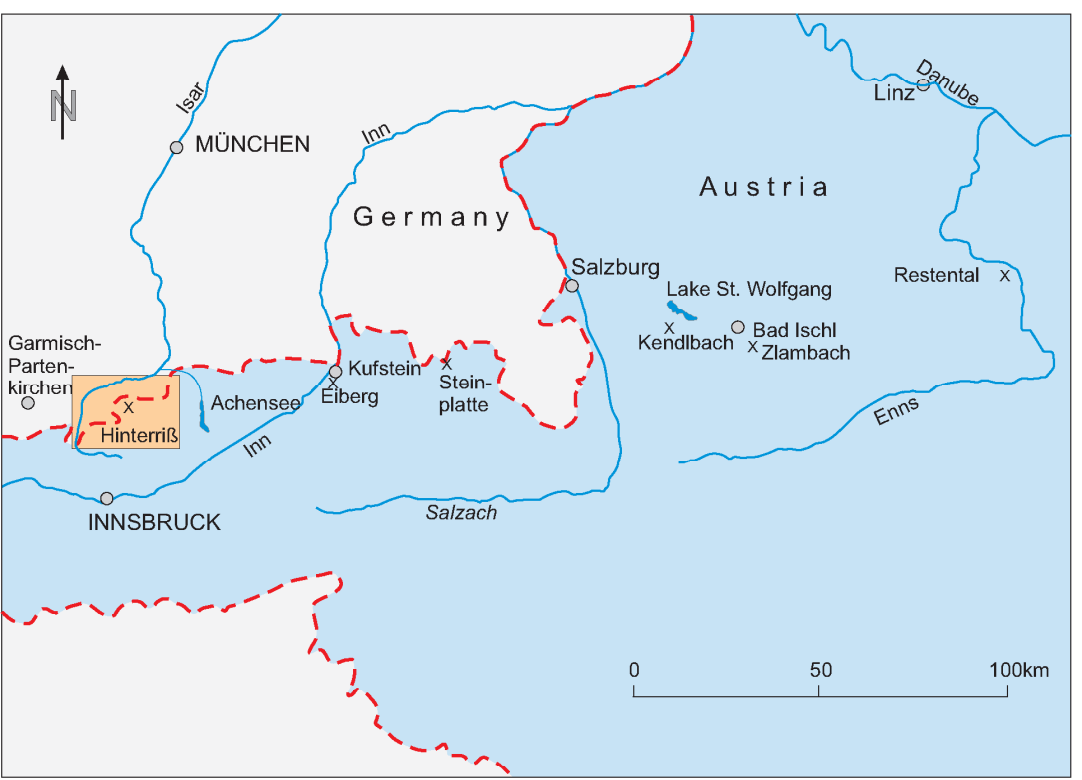

Figure 1. Geographical location of the Triassic-Jurassic boundary sections in the eastern part of the Northern Calcareous Alps. Orange-coloured area Fig. 2.

1994; South America: Prinz, 1985; Hillebrandt, 1994). Investigations in North America (Guex, 1980, 1995; Guex et al., 1998) demonstrated that morphologically different psiloceratids appear distinctly earlier than the traditional $P$. planorbis and may be missing in the epicontinental sea of Northwestern Europe due to shallow marine environments. Psiloceras spelae, described by Guex et al. (1998), and P. tilmanni $(=P$. cf. tilmanni sensu Hillebrandt and Krystyn, 2009) from Nevada, are the oldest representatives of Psiloceras in North America.The occurrence of $P$. spelae below $P$. cf. tilmanni in Peru and Austria makes it to a global form and thus a suitable biomarker for the base of the Jurassic.

The proposed sections (Kuhjoch, Austria; Kunga Island, Canada; New York Canyon, USA; Waterloo Bay, Northern Ireland and St Audrie's Bay - Doniford Bay, England) for the definition of the base of the Jurassic System and the Hettangian Stage at a Global Stratotype Section and Point (GSSP) were published in the ISJS Newsletter 34(1), edited by Paul Bown, Nicol Morton and Jackie Lees, July 2007 and 35(1),

(IUGS) in April 2010. The inauguration of the GSSP took place August 2011 (Morton, 2012).

Considering the long history of research on the Triassic and Jurassic, this may seem surprising, but a major extinction event during this interval strongly affected the traditional fossil biomarkers (ammonoids, conodonts) and a large global sea level drop associated with tectonic and volcanic events resulted in a paucity of sections with continuous marine sequence containing key fossils.

The Northern Calcareous Alps (NCA) of Austria have been known since more than 100 years as a major source of Tethyan (i.e. tropical) Hettangian ammonites (e.g. Wähner, 1882-1898; Lange, 1952; Blind, 1963; Kment, 2000) occurring in sequence with their presumed Triassic precursors (Mojsisovics, 1893; Wiedmann, 1970). The latter are missing in northwestern Europe and are only reported from a few places globally (Tibet: Yin et al., 2007; North America: Tozer, 1979,

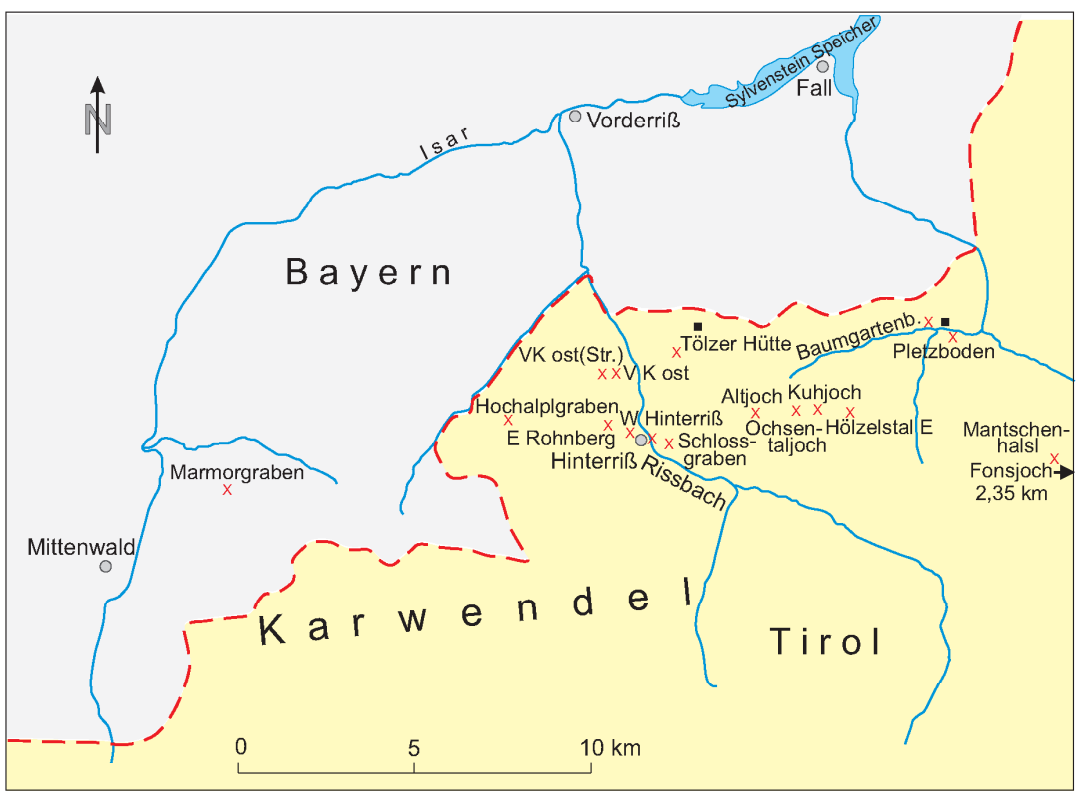

Figure 2. Geographical location of the principal Triassic-Jurassic boundary sections of the western Karwendel Syncline.
2008, edited by Nicol Morton \& Stephen Hesselbo, December 2008 [http://jurassic.earth.ox.ac.uk/newsletters]. The International Subcommission on Jurassic Stratigraphy (ISJS) first made a choice between different primary markers: the ammonoid Psiloceras spelae (at Ferguson Hill section, New York Canyon, Nevada, USA and at Kuhjoch section, Karwendel Mountains, Northern Calcareous Alps, Tyrol, Austria), the ammonite Psiloceras planorbis (at St. Audrie's Bay section, Somerset, England, UK and at Waterloo Bay section, Larne, Northern Ireland), a major evolutionary change of radiolarian faunas (at Kunga Island section, Queen Charlotte Islands, British Columbia, Canada), and a carbon isotope excursion at Ferguson Hill section. The vote of the Subcommission was clearly in favor of Psiloceras spelae: Ps. spelae $53.7 \%$; Ps. planorbis $19.4 \%$; carbon isotope excursion $16.4 \%$; radiolarian turnover $10.5 \%$. Kuhjoch was then selected as GSSP for the base of the Jurassic System, Lower Jurassic Series and Hettangian Stage (Kuhjoch section 56.1\%; Ferguson Hill section 31.6\%; abstain 12.3\%). The section was chosen because, beside its continuous sedimentation, it contains the richest known marine fauna in the world for this time period and an abundant microflora allowing a cross-correlation with the continental realm and a low diagenetic overprint, which allows chemical proxies to be applied. A well preserved species of Psiloceras (P. spelae tirolicum) (Hillebrandt and Krystyn, 2009) within the lower Tiefengraben Member correlates with and is comparable with the oldest Psiloceras (P. spelae spelae) in North America (Muller Canyon, Nevada, USA), but it is much better preserved (e.g. aragonitic shell, phragmocone and body chamber, whorl section and complete suture line) than the crushed North American specimens, which lack the shell, an exact cross section, and the suture line.

\section{Geographical setting}

The GSSP at Kuhjoch is located on the southern flank of the Karwendel Syncline, about 25 km north- 


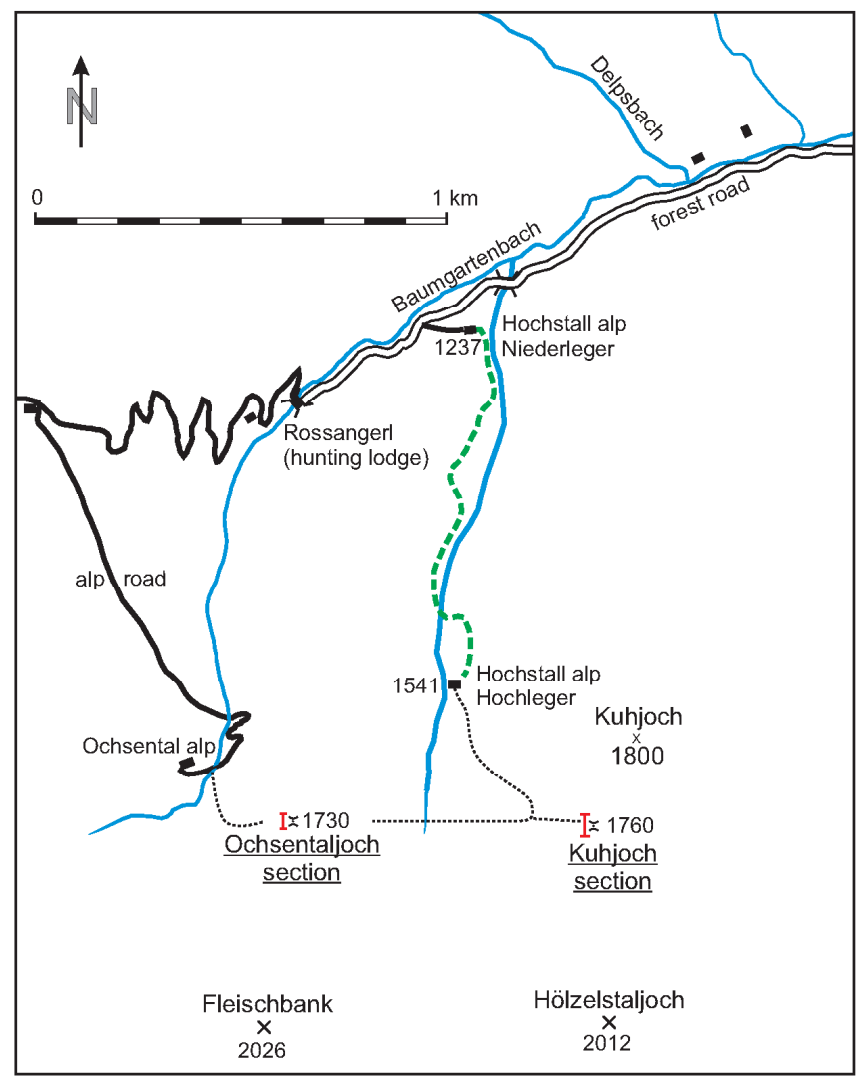

Figure 3. Geographical location of and access routes to the Kuhjoch and Ochsentaljoch sections.

north-east of Innsbruck and $5 \mathrm{~km}$ east-north-east of the village of Hinterriss. On the 1:50.000 scale topographic map of Austria (sheet 118: Innsbruck); the coordinates are $47^{\circ} 29^{\prime} 02^{\prime \prime} \mathrm{N} / 11^{\circ} 31^{\prime} 50^{\prime \prime} \mathrm{E}$. It is accessible through the Baumgartenbach valley on a $16 \mathrm{~km}$ long forest road (driving permit from the OEBF $=$ Österreichische Bundesforste, oberinntal@ bundesforste.at) starting south of the village of Fall in Bavaria (Germany), with a 1.5 to 2 hours walk from the Hochstallalm Niederleger (Fig. 3). Kuhjoch (Fig. 4) [mountain pass located between Kuhjoch peak (not named on topographic map 1:50 000) and Hölzelstaljoch peak; Fig. 3] and Ochsentaljoch [located $750 \mathrm{~m}$ to the west (mountain pass between Ochsental and Hochstall valleys); $\left.47^{\circ} 29^{\prime} 0^{\prime \prime} / 11^{\circ} 31^{\prime} 50^{\prime \prime}\right]$, are situated within a natural reserve (Karwendel Naturpark) at altitudes of $1700-1800 \mathrm{~m}$, i.e. beyond the main tree and bush growth zone (Figs. 4, 7) (air photographs and topographic maps: http://tiris.tirol.gv.at/web/index.cfm; search for place name: Hochstall-Hochleger). Sections were excavated and studied on both sides of the pass (Kuhjoch West and Kuhjoch East) (Fig. 8). The "Golden Spike" (Fig. 9) was fixed at Kuhjoch East because a higher guarantee of conservation (steep slope at Kuhjoch West and flat slope at Kuhjoch East). This guarantees long-term exposure and conservation with respect to protection status. There is enough space to extend, mainly at the western side of the pass, at any time fresh outcrops of the weathering marls. For reasons of protection, the section Kuhjoch East was fenced in by a wooden hoarding (Fig. 9).

\section{Geological Setting}

Expanded and highly fossiliferous sedimentary successions across the Triassic-Jurassic (T-J) boundary in the NCA are mainly found in the so-called Eiberg Basin, a Rhaetian intraplatform depression, which can be traced over $200 \mathrm{~km}$ from the Salzkammergut (Kendlbach, Upper Austria) in the east to the Lahnewiesgraben valley (northwest of Garmisch-Partenkirchen, Bavaria) in the west (Fig. 1). In the western part of this basin, the Karwendel Syncline is a local, EastWest trending synclinal structure, approximately $30 \mathrm{~km}$ long, within

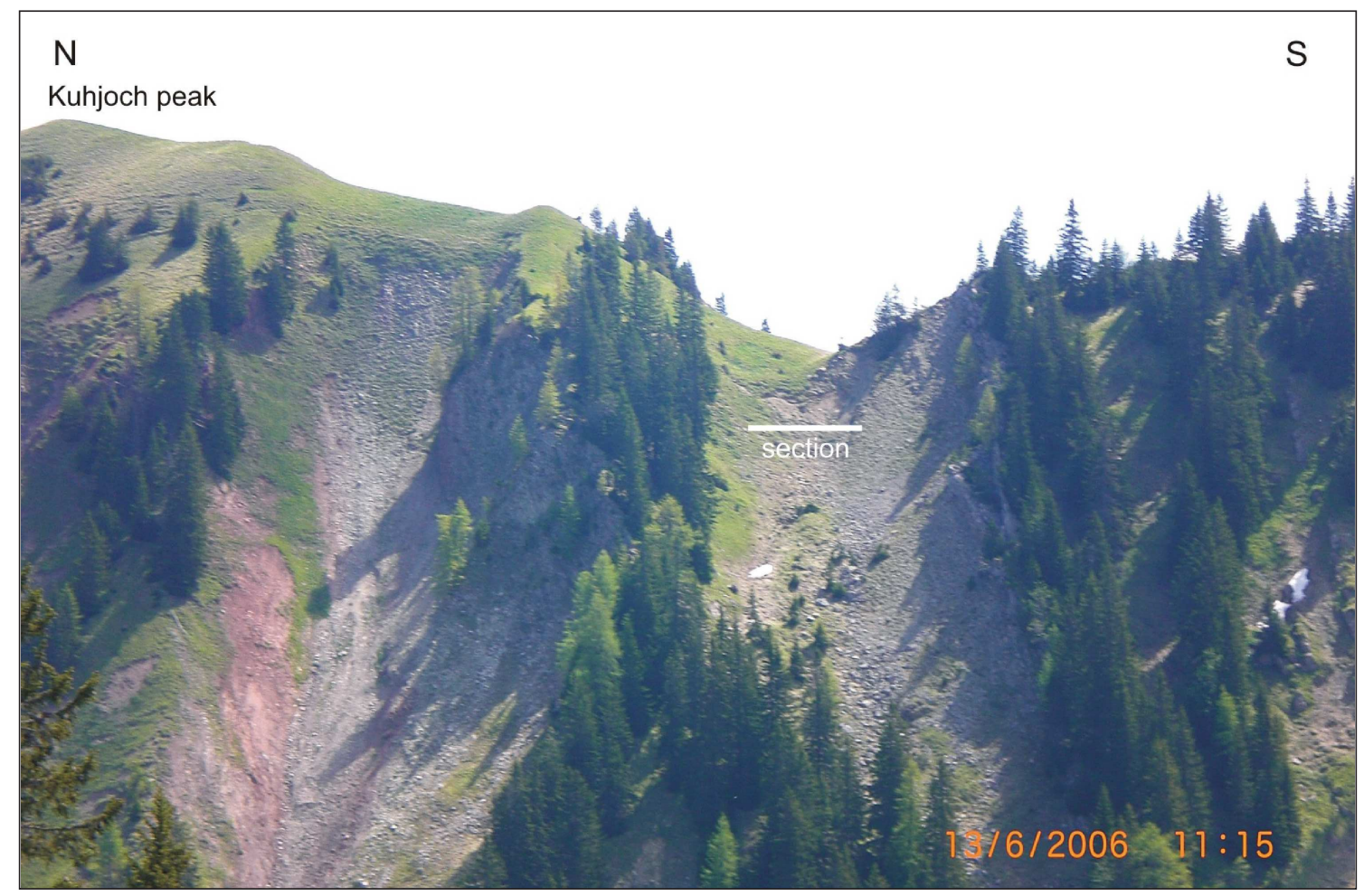

Figure 4. Photograph of Kuhjoch mountain and Kuhjoch pass with location of Kuhjoch West section indicated by white line. 
the Inntal nappe of the western Northern Calcareous Alps. It is wide and relatively flat near the Achensee in the east (Fig. 1) and narrows towards the west with increasingly steep to overturned flanks at its western end close to Mittenwald (Fig. 2) - see Geological map 1:75000, sheet 29, Innsbruck und Achensee by Ampferer and Ohnesorge (1912) (out-of-print); Geological map (Geofast) 1: 50000, sheet 118: Innsbruck, compilation by Moser (2008), Geologische Bundesanstalt (2008/09); Geological map 1:10000 by S. Schütz (1974) (unpublished) (Figs. 5, 6)

$\mathrm{T} / \mathrm{J}$ boundary sections east of the Karwendel Syncline are classical localities and have been studied by various authors (references in Kürschner et al., 2007). The boundary sections of the Karwendel Syncline, belonging to the western part of the Eiberg Basin, have been much less studied and detailed biostratigraphic information about the Tiefengraben Member is is only known recently. Most of the recently studied outcrops are situated on the southern flank of the Karwendel Syncline, and at least five of them (Hochalplgraben, Rissbach, Schlossgraben, Ochsentaljoch and Kuhjoch; Fig. 2) have become important as a result of the findings of new psiloceratids distinctly older than the well-known earliest Psiloceras of England (P. erugatum, $P$. planorbis) and the Alps ( $P$. calliphyllum). The ammonites of the bed with $P$. calliphyllum can be compared with the earliest Psiloceras in England (Bloos, 2004, Page, 2003, Page et al.,
2010) and are found at the GSSP about $18.5 \mathrm{~m}$ above the horizon with $P$. spelae. (Hillebrandt and Krystyn, 2009).

The Eiberg Basin was an intraplatform trough bordered to the southeast by a broad Rhaetian carbonate platform (Dachstein Lagoon) with, locally, fringing reefs and, further southeast, an outer shelf (Hallstatt Basin) transitional to the Tethys Ocean (Brandner and Gruber, 2011). Another partly terrigeneous-influenced carbonate ramp (Oberrhaet limestone lagoon) of the Lechtal and Allgäu nappes existed north of the Eiberg Basin. Within this unit, intraplatform depressions with sedimentary successions across the Triassic-Jurassic (T-J) boundary similar to those of the Eiberg basin are also found (e.g. Restental, Upper Austria; NE Aschau, Chiemsee, Bavaria; Tannheim, Allgäu; Lorüns, Vorarlberg). Earliest Jurassic ammonites are not found but a biostratigraphic correlation is possible with foraminifers (Praegubkinells turgescens). The Allgäu Unit was bordered landward by the Keuper area of Southern Germany (or was separated from the latter by the Vindelician High).

The Rhaetian Kössen Formation spreads over the Hauptdolomite Lagoon with subtidal mixed limestone and clay bearing bioclastic rocks. The sedimentary facies of the Rhaetian Kössen Formation changed around the Middle to Late Rhaetian boundary (base of marshi Zone) with the onset of a basinal facies (Eiberg Member) above the underlying shallow water sequence of the Hochalm Member

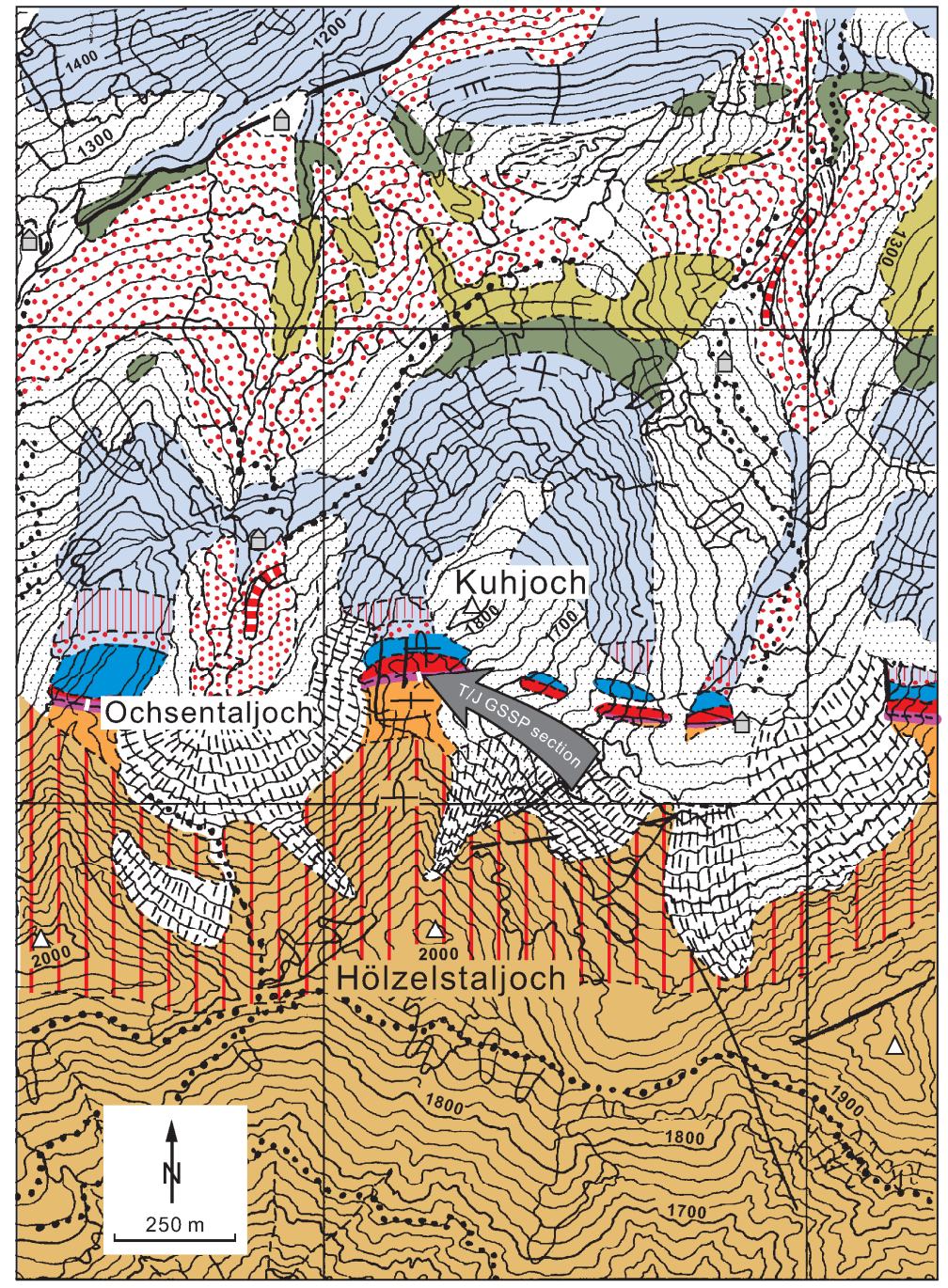

Figure 5. Geological map of the Kuhjoch area (Schütz, 1974).
Holocene

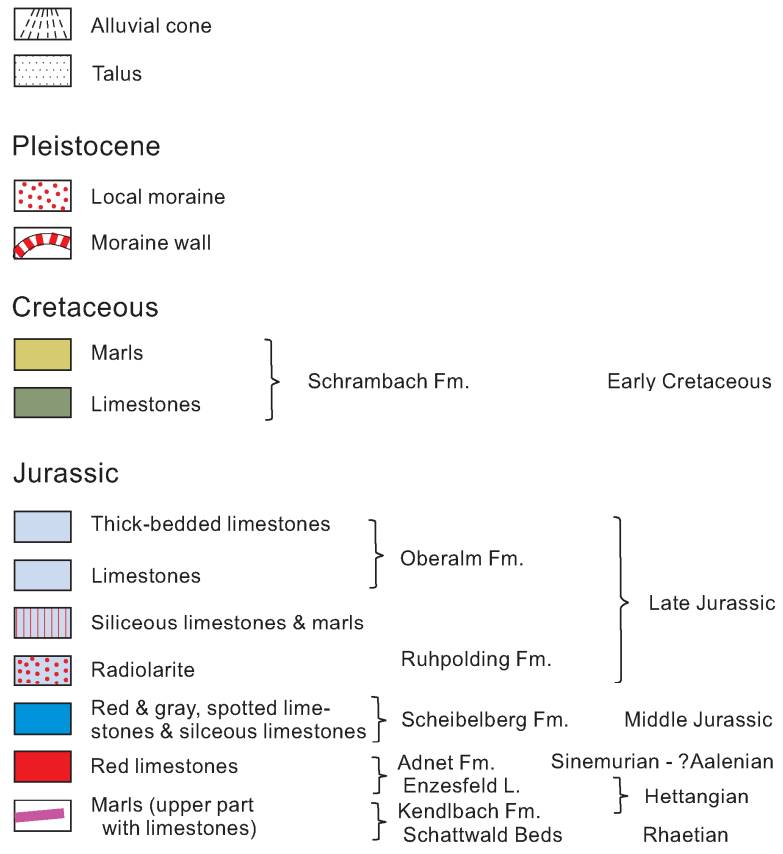

Triassic

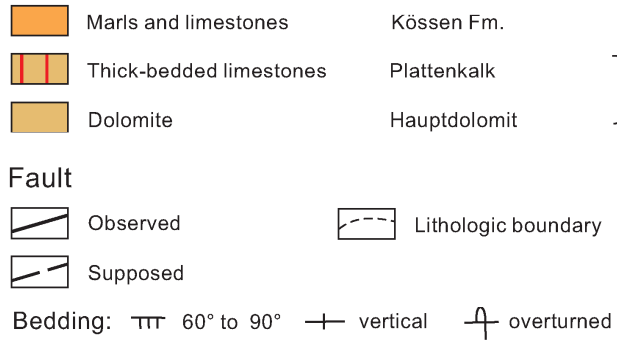

Figure 6. Key to the geological map of the Kuhjoch area. 


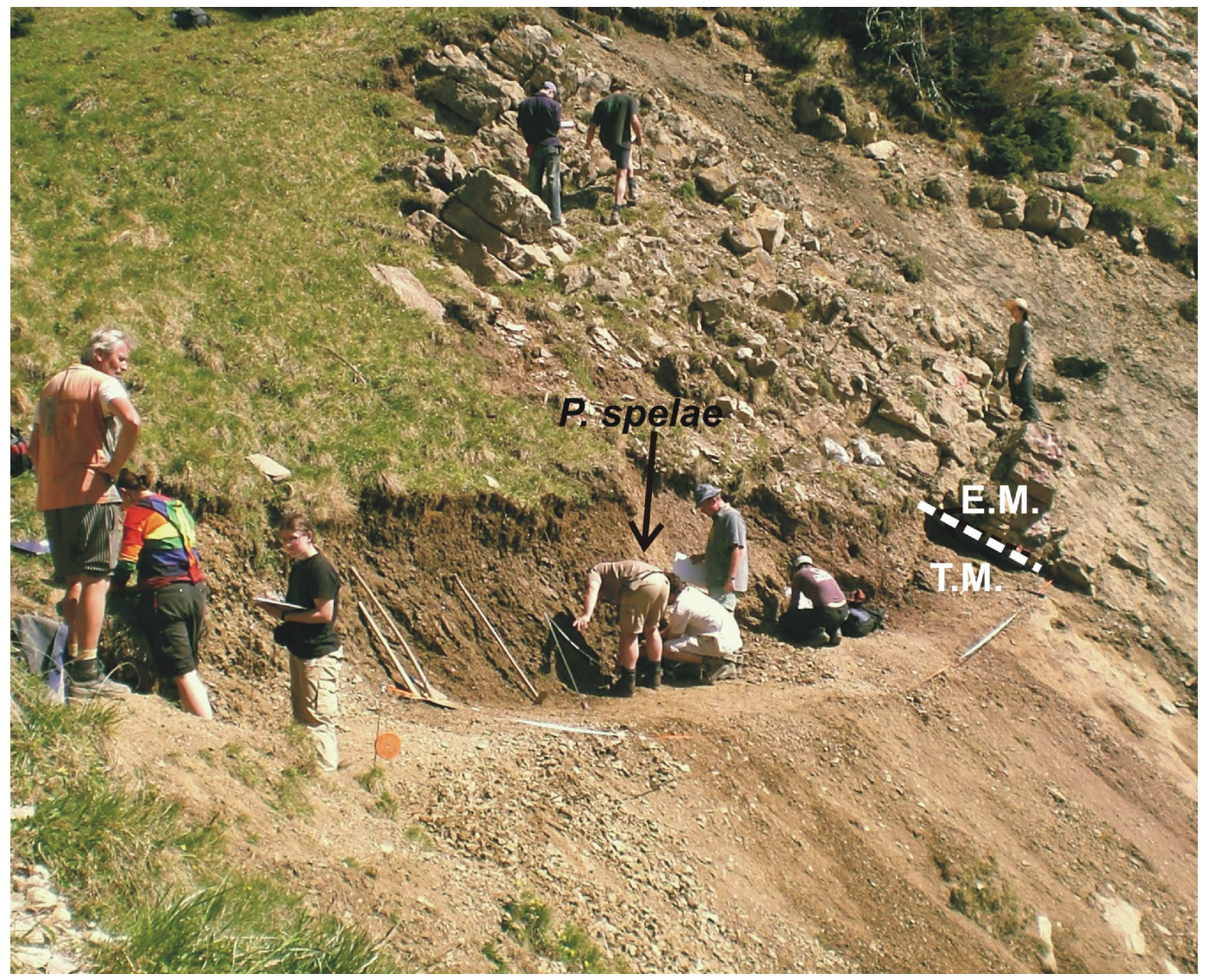

Figure 7. Section Kuhjoch West, outcrop situation June 2006. E.M./T.M. boundary Eiberg Member/Tiefengraben Member (see also Fig. 20A); P. spelae with arrow = horizon with Psiloceras spelae tirolicum; third person from left $=$ level with Psiloceras pacificum; leftmost person (L. Krystyn) approx. first arenitic beds.

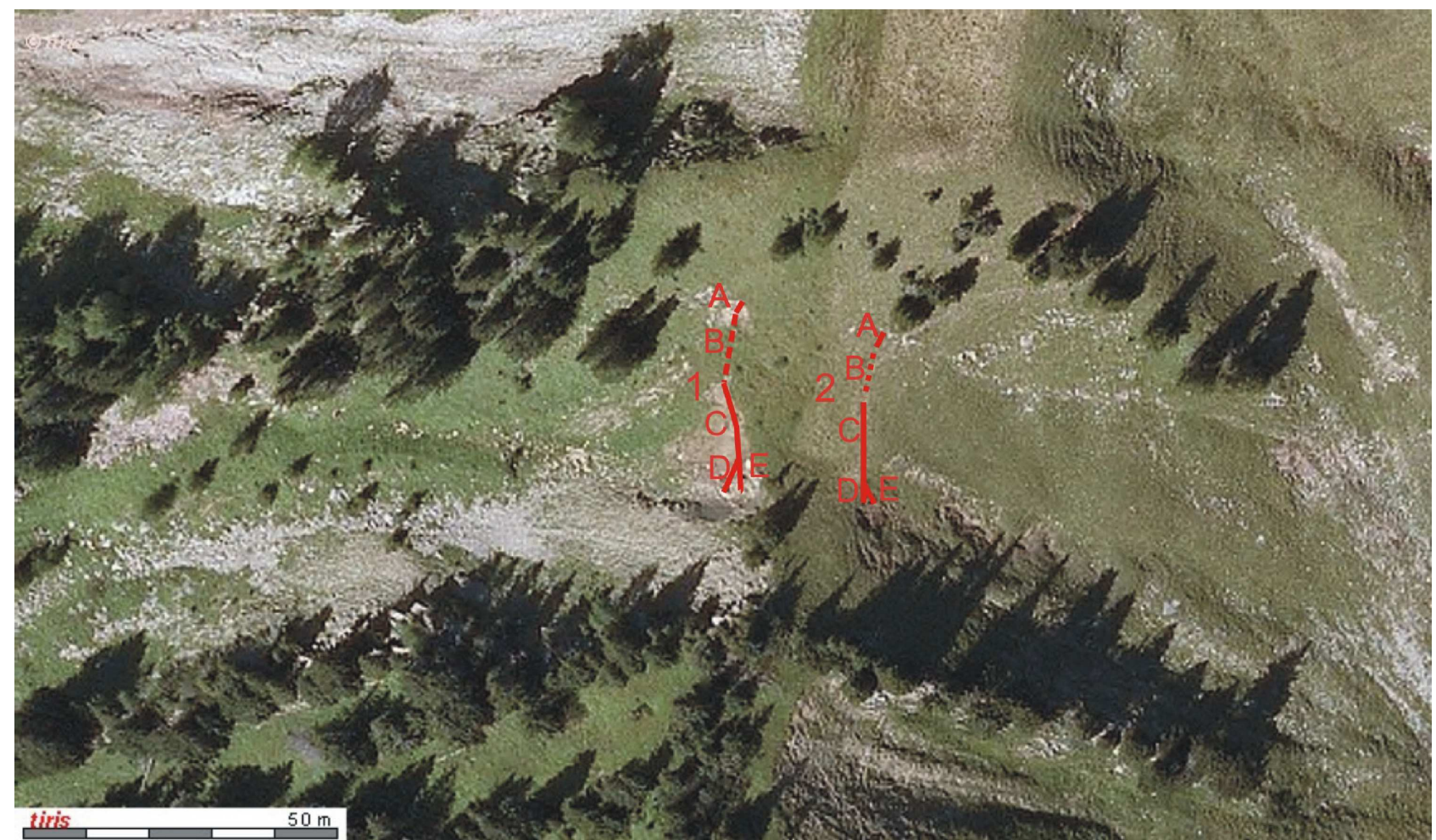

Figure 8. Air photograph (taken 2009, before Kuhjoch East was excavated) of Kuhjoch pass with sections Kuhjoch West (1) und East (2). 


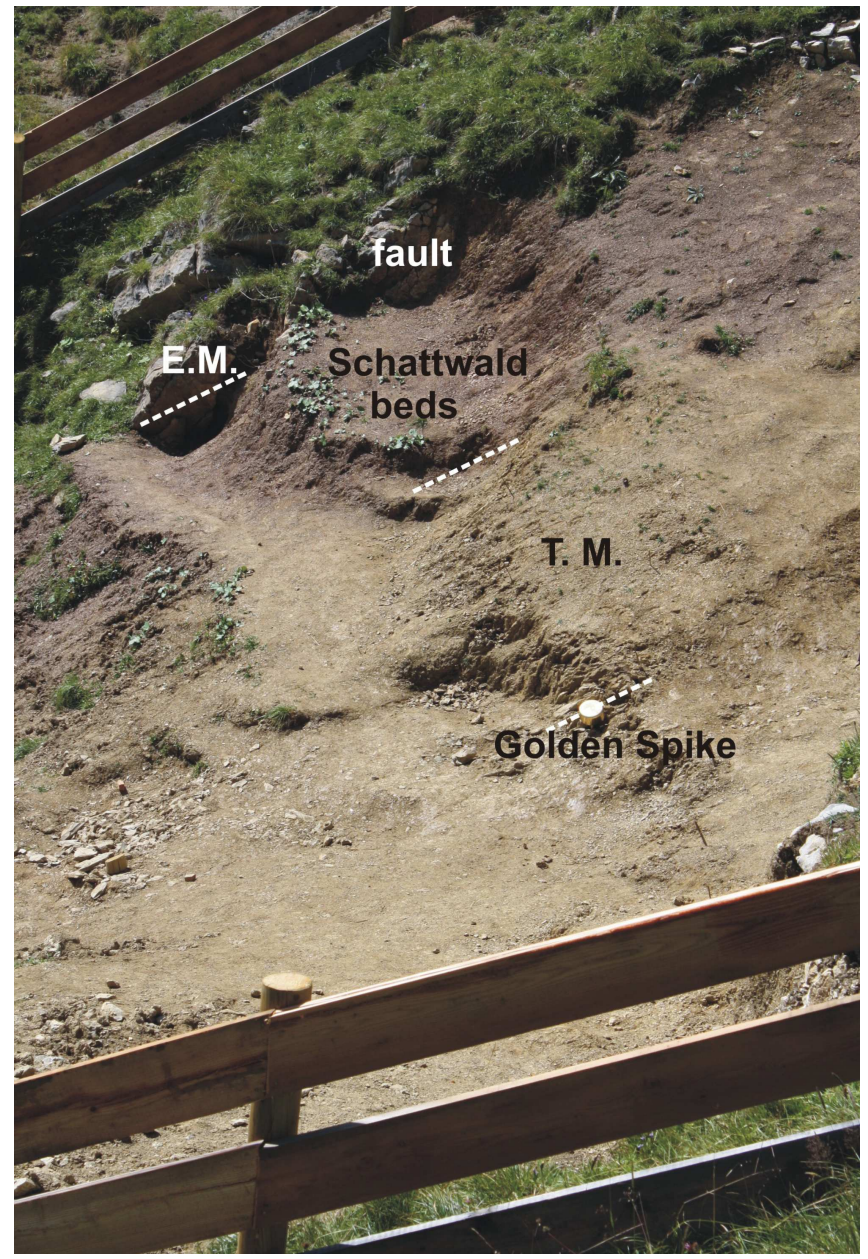

Figure 9. Section Kuhjoch East (taken August 2011) with "Golden Spike” at the Triassic-Jurassic boundary. View from North to South, beds vertical to slightly overturned; Fault = fault surface; E.M. = Eiberg Member; T.M. = Tiefengraben Member.

(Golebiowski, 1989). The continuously subsiding Eiberg Basin reached 150-200 m water depth in Late Rhaetian time and was, therefore, less affected by the end-Triassic sea level drop, which led to widespread and longer-lasting emersion of the surrounding shallow water areas. Marine conditions prevailed in the basin across the System boundary, though a distinct and abrupt lithological change from basinal carbonates of the Eiberg Member to marls and clayey sediments of the lower Kendlbach Fm. took place (Tiefengraben Mb., corresponding to the British pre-Planorbis Beds), which is interpreted as a result of this sea level drop. The change is said to be connected with the start of the volcanism of the Central Atlantic Magmatic Province (CAMP) whose record in the Eiberg Basin was recently evidenced by Pálfy and Zajzon (2012) from elemental geochemistry and mineralogy for the bituminous topmost layer of the Kössen Formation at Kendlbach.

The drastic lithological change was interpreted during recent decades as the T-J boundary (Golebiowski, 1990; Hallam and Goodfellow, 1990) because it coincides with the disappearance of typical Triassic fossils such as ammonoids and conodonts. New studies demonstrate, however, that the lowest meters of the Tiefengraben Mb. (= "Rhaetische Grenzmergel" sensu Fabricius, 1960, 1966 including the reddish Schattwald Beds) still yield a Triassic microand nannoflora (Kürschner et al., 2007). The regression was fast; it started at the end of the Kössen Formation with a bituminous layer, culminated with the Schattwald Beds near the end of the Rhaetian and was followed by a slow long-term sea level rise that started in the latest Rhaetian, continued through the Hettangian and exceeded the Rhaetian highstand relatively late in the late Sinemurian (Krystyn et al., 2005). McRoberts et al. (2012,fig. 5) assume the lowest point of sea level fall in the uppermost part of the Eiberg Member (sensu McRoberts et al., 2012) followed by a continuous sea level rise from the Tiefengraben Member upwards. The Kendlbach Formation is replaced up-section by Early Jurassic carbonates of both increasing water depth and pelagic influence (Adnet Formation).

Within the Eiberg Basin between Kendlbach (Lake St. Wolfgang) and Garmisch-Partenkirchen (Fig. 1), all sections show the same sedimentary record across the T-J boundary with varying carbonate vs. clay content depending on their more marginal or more distal position within the basin. A general increase in thickness of the Tiefengraben Member can be observed from east to west, nearly double in the Karwendel syncline compared with the eastern Kendlbach and Tiefengraben sections. With a thickness of more than $20 \mathrm{~m}$, the Karwendel Syncline exposes one of the most expanded Triassic-Jurassic boundary successions of all known Alpine and worldwide marine sections. Among the diverse T-J boundary sections of the western Eiberg Basin, therefore, the Kuhjoch Pass was selected as GSSP for the base of the Jurassic because it presents the best continuously available and most complete T-J boundary sections of the area. Only the topmost part of the boundary sequence, with the transition to the $P$. calliphyllum horizon, 10 to $18 \mathrm{~m}$ above the GSSP level, has been studied in more detail at a neighbouring locality (Ochsentaljoch) about $750 \mathrm{~m}$ to the west of Kuhjoch (Fig. 3), where this interval is better exposed and suggest a clearer presentation.

\section{Stratigraphy}

\section{Position of main boundary-relevant ammonite levels 1 to 7 (Fig. 10)}

Three new ammonite levels (levels 2, 3 and 4) have been found at GSSP Kuhjoch West which are located between the widely distributed and long-known Choristoceras marshi found up to the uppermost beds of the Upper Rhaetian Eiberg Member (level 1) and the also long-known Lower Hettangian limestone bed with Psiloceras calliphyllum (level 5) (Fig. 10) of the Breitenberg Member. Between the Eiberg and Breitenber Members is positioned the $22 \mathrm{~m}$ thick, continuous succession of marls and marlstones of the Tiefengraben Member with the T-J boundary interval and following ammonite levels:

ammonite level (2) with Psiloceras spelae tirolicum from 5.80 to $6.20 \mathrm{~m}$;

ammonite level (3) with Psiloceras ex gr. tilmanni at 7.6-8.0 m;

ammonite level (4) with Psiloceras cf. pacificum at 12.0-12.4 m above the base of the member (Hillebrandt and Krystyn, 2009).

The base of the level with Psiloceras spelae tirolicum was found at Kuhjoch East $6.30 \mathrm{~m}$ above the top of the Kössen Formation (Eiberg Member). Levels (3) to (5) were also found in Ochsentaljoch (Fig. 10).

The clays and marls of the Tiefengraben Member were formerly called "Rhaetische Grenzmergel" [type locality Marmorgraben, western Karwendel Syncline (Fig. 2)] (Fabricius, 1960, 1966) and 
correspond in current nomenclature to the Tiefengraben Member of the Kendlbach area where the member differs by additional marly limestone intercalations. The overlying Breitenberg Member (named "Liasbasiskalk" by Ulrich, 1960 in the Karwendel Syncline) is rather uniformly developed and consists of a 2-3 m package of limestones with ammonite level (5) close to the top. As ammonites of several distinct biohorizons ( $P$. calliphyllum/costosum and P. naumanni horizons) occur closely together, level (5) may be condensed and is thought to correlate with a major part of the Planorbis Zone of Northwestern Europe (Fig. 22; Bloos, 2004). Levels 6 and 7 (Kuhjoch) (Fig. 10) are also condensed and can be correlated with the Middle Hettangian Alpine Megastoma and the Late Hettangian Alpine Marmoreum zones (Hillebrandt and Kment, 2011).

\section{Lithostratigraphic description of the type sections (Kuhjoch and Ochsentaljoch)}

\section{a) Kuhjoch}

On the south to north orientated crest of Kuhjoch, a steeply dipping continuous sequence of more or less overturned Rhaetian (Kössen Fm.) to Upper Jurassic sediments (Ruhpolding Radiolarite Fm.) is exposed (Schütz, 1974), perpendicular to the crest and bedding strike. A narrow topographic depression, visible both on the maps and in the field (Figs. 4, 5, 8), corresponds to the documented sections. The first samplings (2005 to 2009) were mainly carried out on the western side of the Kuhjoch pass (Fig. 8; section 1A-E). The first micropalaeontological samples from the transition of the Eiberg Member to the Schattwald Beds and Tiefengraben Member (section 1D) were taken some meters downslope section 1E. The samples studied by Bonis et al. (2009) for palynology come from section 1D. A small local fault in the uppermost part of the Schattwald Beds of section $1 \mathrm{E}$ results in a short sedimentary hiatus as is evident by a sharp shift in the $\mathrm{C}$-isotope curve and the lack of a pollen assemblage zone (Bonis et al, 2009; Ruhl et al., 2009) (Figs. 19, 23, 24). The natural outcrop Kuhjoch East section (Fig. 8; 2A-D and E; Fig. 9), 20 m eastward from Kuhjoch West, was enlarged in 2010 and 2011 by an excavator (transported by helicopter) to the lower and middle part of the Tiefengraben Member. Section 2D ends with a fault against the Kössen Formation. Section 2E shows an undisturbed transition from the Eiberg Member to the Tiefengaben Member and no fault at the top of the Schattwald Beds. The level with P. spelae tirolicum is found $6.30 \mathrm{~m}$ above the uppermost Kössen Formation (T-Bed). This means that Kuhjoch West (Fig. 8; section 1 E) lacks approx. $0.5 \mathrm{~m}$ of upper Schattwald Beds. It is difficult to prove if the fault at Kuhjoch West (uppermost part of Schattwald Beds) is the same fault at Kuhjoch East (basis of the Schattwald Beds).

\section{Kuhjoch West}

The Kuhjoch West section starts $3.8 \mathrm{~m}$ below the top of the Kössen Formation/Eiberg Member with a package of well bedded and variably thick (up to $50 \mathrm{~cm}$ ) bedded grey bioturbated limestones (bioclastic wackestones) overlying $5 \mathrm{~m}$ of black marls with pyrite nodules and rare thin $(5-10 \mathrm{~cm})$ limy mudstone intercalations (Fig. 15). The 20 $\mathrm{cm}$ thick topmost bed (= T-Bed in Fig. 20a,b) of the Eiberg Member differs by darker colour and platy weathering. Due to an increased clay content it is softer than the pure limestones below and thinly laminated in its upper half. The top of this bed $(\sim 1 \mathrm{~cm}$ thick and mmlaminated) is black and bituminous, rich in bivalves and fish remains (scales) indicating an anoxic event and a first regression [T-Bed is employed differently by McRoberts et al. (2012) by restricting it to the bituminous very top of T-Bed sensu Hillebrandt et al. (2007). The original definition is retained here because of the lithologic and faunistic uniformity of the whole bed]. Above, the Kendlbach Formation is divided into the lower $22 \mathrm{~m}$ thick terrigeneous Tiefengraben Member and above the following $3 \mathrm{~m}$ thick calcareous Breitenberg Member.

Grey to brownish clay-rich marls (up to $13 \mathrm{~cm}$ thick) with concretions of pyrite and worm-shaped traces constitute the base of the Tiefengraben Member and are overlain by yellowish weathering, partly laminated marls (ca. $30 \mathrm{~cm}$ thick) passing into reddish, partly laminated, silty clays approximately $2 \mathrm{~m}$ thick (Figs. 9, 19, $20 \mathrm{a}, \mathrm{b})$, These are comparable with also reddish, silty clays known as Schattwald Beds in the Allgäu nappe in the north between Schattwald and Pfronten (Allgäu mountains, type region of the Schattwald Beds). Sections with Schattwald Beds of the Allgäu nappe were also studied at Aschau, Chiemsee (Bavaria) and Restental, Upper Austria (Golebiowski, 1990) as also the Lechtal nappe (e.g. Peischelspitze south of Lechtal valley) and western NCA (e.g. Lorüns, Vorarlberg; McRoberts et al., 1997). Grey intercalations characterize the transition to the overlying main part of the Tiefengraben Member, $19.5 \mathrm{~m}$ thick. Ammonite level (2) with P. spelae tirolicum is located $3.2 \mathrm{~m}$ above the Schattwald Beds, ammonite level (3a) with $P$. ex gr. P. tilmanni 2 m higher than (2) and ammonite level (4) with $P$. cf. pacificum $4 \mathrm{~m}$ higher up in the section than (3a) (Hillebrandt and Krystyn, 2009).

Approx. $8 \mathrm{~m}$ above the Schattwald Beds the marls become more silty and from $10 \mathrm{~m}$ upwards also finely arenitic. A first arenitic bed (15 to $20 \mathrm{~cm}$ thick) occurs at around $11 \mathrm{~m}$ above the Schattwald Beds. The remaining part of the Tiefengraben Member, with the transition to the Breitenberg Member ("Liasbasiskalk" of Ulrich, 1960), is not well exposed. A naturally well exposed outcrop of this part of the section is found at Ochsentaljoch (750 m west of Kuhjoch; see below).

The exposed part of the Breitenberg Mb. consists at Kuhjoch West and East (Fig. 8: 1A, 2A; 10) of grey thin-bedded limestones with thin black hard marl layers and a top bed $(10$ to $15 \mathrm{~cm})$ that contains, in the middle and upper part, a condensed fauna of the Calliphyllum Zone, including a hardground layer rich in ammonites partly preserved as limonitic steinkerns. At Kuhjoch and several other sections of the southern and northern flank of the Karwendel Syncline, the next two or three limestone beds contain condensed succession of ammonites of Middle and Late Hettangian age (Kment, 2000; Hillebrandt and Kment, 2009, 2011). At Kuhjoch, there follows above the calliphyllum horizon a grey, sparry limestone ( $8 \mathrm{~cm}$ thick), a brownish, micritic limestone bed (10 cm thick), an ochre colored, micritic limestone with gray limestone clasts and Alsatites $\mathrm{cf}$. liasicus of Middle Hettangian age (= Enzesfeld limestone) $(8 \mathrm{~cm}$ thick) and a brownish, sparitic limestone $(15 \mathrm{~cm}$ thick) with a limonitic crust at the top and Alpinoceras haueri (Marmoreum Zone) of Late Hettangian age. On the western slope of Kuhjoch, the limonitic crust of this bed yielded Middle Hettangian ammonites (Megastomoceras megastoma and Alsatites proaries). On the eastern slope, a loose block of the Enzesfeld limestone (10 cm thick) contained Middle Hettangian ammonites (e.g. Megastomoceras megastoma and Storthoceras frigga). Nodular limestones of the Adnet Formation of Sinemurian age follow above. 


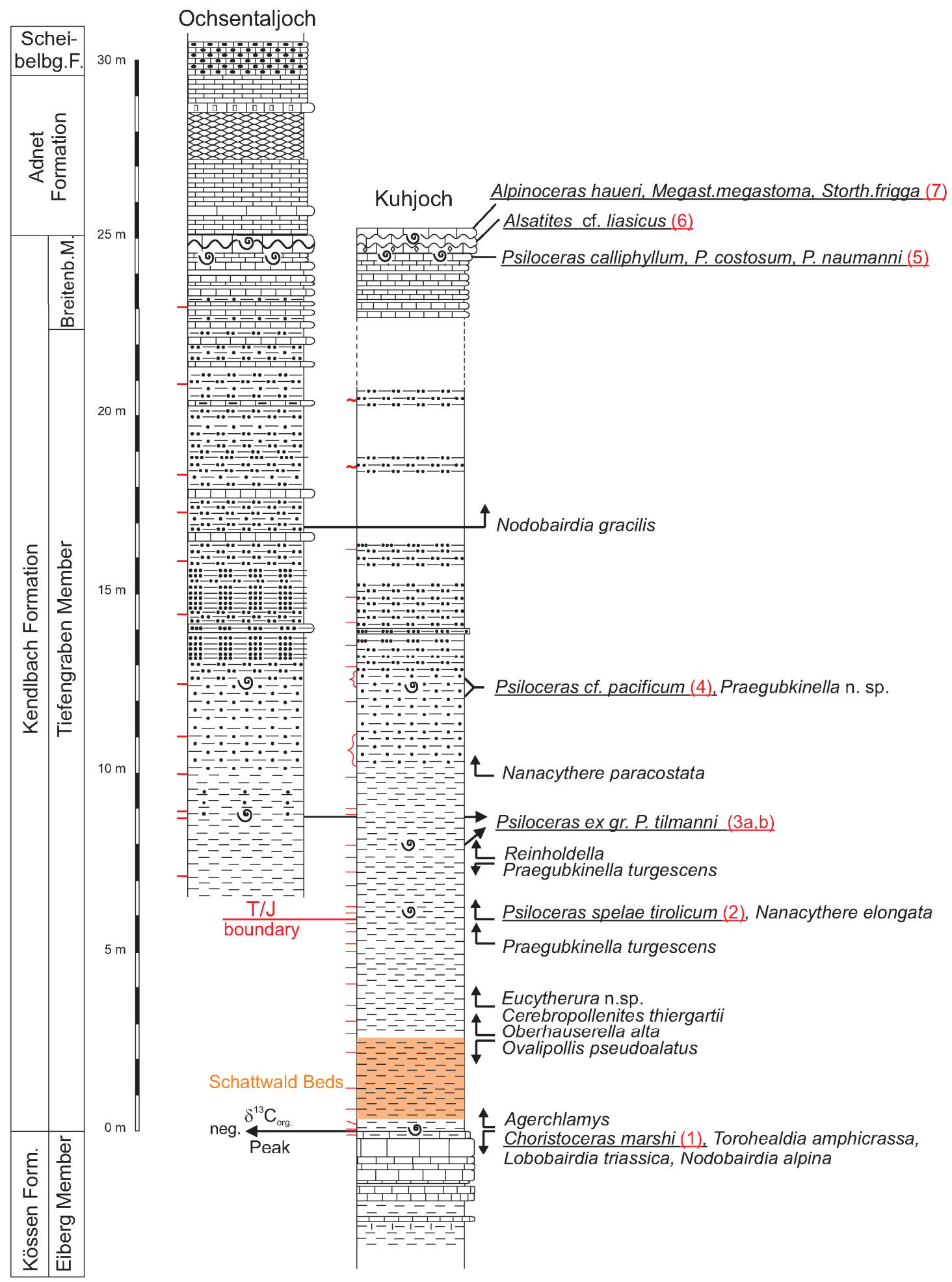

Figure 10. First and last occurrences of biostratigraphically important fossils from the Triassic-Jurassic GSSP (Kuhjoch West).

\section{Kuhjoch East}

Only the uppermost beds of the Kössen Formation crop out. The band of well-bedded and variably thick (up to $50 \mathrm{~cm}$ ) gray, bioturbated limestones yielded Choristoceras. The transition from the Eiberg Member to the Tiefengraben Member is only complete at the partial section 2E (Fig. 8) [left part with E.M. (Eiberg Member) on Fig. 9] where the T-Bed (as originally defined) with its bituminous top is present. The following yellowish marls are strongly weathered and pass into the Schattwald Beds. At partial section 2 D (Fig. 8: 2D the Schattwald Beds are faulted against a limestone bed of the uppermost Kössen Formation (right part with "fault" on Fig. 9). The Schattwald Beds are $2.8 \mathrm{~m}$ thick and pass into the Tiefengraben Member. An inner whorl of the first $P$. spelae tirolicum was found $3.2 \mathrm{~m}$ and poorly preserved fragments and specimens 3.6 to $3.7 \mathrm{~m}$ above the Schattwald Beds. A fragment with inner nodes of Psiloceras tilmanni group was 
found $4.7 \mathrm{~m}$ and shell fragments with suture lines of ?Psiloceras in samples 6.2 and $8.4 \mathrm{~m}$ above the Schattwald Beds. The marls of the Tiefengraben Member are usually more strongly weathered than those from Kuhjoch West. Aragonitic shells and in part also calcitic shells tend to be dissolved. Reinholdella n.sp. in some samples is very frequent in the upper part (Fig. 12). A first arenitic bed (15 to $20 \mathrm{~cm}$ thick) occurs at $12 \mathrm{~m}$ above the Schattwald Beds followed by a second one $50 \mathrm{~cm}$ above the first arenitic bed. The outcrop ends in the arenitic interlayers of the Tiefengraben Member due to a meter thick moraine that covers the interval to the Breitenberg Member.

\section{b) Ochsentaljoch}

Better exposures of the upper half of the Tiefengraben Member have been found at Ochsentaljoch. A mountain trail crosses the steeply dipping sequence, which starts with the same grey marls as at Kuhjoch. An exact correlation with the latter is possible by the presence of ammonite level (4) $4 \mathrm{~m}$ above the base of the measured section. Higher up in the section follow sandy marls $(1.5 \mathrm{~m})$ with rare thin arenitic layers (at Kuhjoch too weathered and therefore not identified) and at the top a thicker arenitic bed $(20 \mathrm{~cm})$ that matches the first arenitic bed of the Kuhjoch sections. The following $2 \mathrm{~m}$ are composed of marls, with some silty arenitic beds up to $15 \mathrm{~cm}$ thick, overlain by a fine-grained limestone bed $(20 \mathrm{~cm})$ with bivalves and brachiopods at the base. Grey, partly silty marls continue for another $4.3 \mathrm{~m}$ with 2 marly limestone beds (each $15-20 \mathrm{~cm}$ ) at $0.9 \mathrm{~m}$ and $3.3 \mathrm{~m}$ above the bed with bivalves and brachiopods. The Breitenberg Member starts with a pure limestone bed $(15 \mathrm{~cm})$ overlain by dark grey marls $(0.3 \mathrm{~m})$ that are followed by thin hard intercalations of marlstones between wavy bedded, grey bioclastic limestones $(2 \mathrm{~m})$. No fossils have been collected in the overlying Calliphyllum bed and the Middle to Late Hettangian condensed layers, which are identified by lithological affinity with the Kuhjoch counterparts. Platy to nodular red limestones of the Adnet Formation ( $4.5 \mathrm{~m}$ ) form the top of the section up to the cherty limestones of the Late Sinemurian Scheibelberg Formation.

\section{Palaeontology of the Kuhjoch and Ochsentaljoch Sections}

The palaeontological record at Kuhjoch is clearly marked by the end-Triassic mass-extinction coincident with the top of the Kössen Formation (top of T-Bed) (Kürschner et al., 2007; Hillebrandt and Kment, 2011; McRoberts et al., 2012). The top of the T-Bed records the onset of the main extinction pulse. The lowermost 0.3 meter (Fig. $20 \mathrm{a}, \mathrm{b})(0.4 \mathrm{~m}$ at Schlossgraben section) of the Tiefengraben Mb., called Grenzmergel s. str. (Hillebrandt and Kment, 2011) or initial phase of extinction (McRoberts et al., 2012), records opportunistic species of bivalves and further levels of foraminifer and ostracod extinctions. The Schattwald Beds yield almost no micro- or macrofossils and represent the peak phase of extinction (McRoberts et al., 2012).

The extinction (e.g. Hallam and Wignall, 1999; Hautmann, 2004) affected similarly the terrestrial fauna and flora (McElwain et al., 1999, 2009; van de Schootbrugge et al., 2007; Whiteside et al., 2007). The Central Atlantic Magmatic Province (CAMP) is the most often cited cause for this extinction (e.g. Palfy et al., 2000, Marzoli et al., 2004, Payne and Kump, 2007; van de Schootbrugge et al., 2009;
Schoene et al., 2010). Injection of methane to the atmosphere (Ruhl and Kürschner, 2011; Ruhl et al., 2011) has also been inferred, but has been challenged by Lindström et al. (2012). Whatever the cause, the subsequent longer lasting greenhouse effect led to further biotic decimation (McElwain et al., 1999). A phase of slow regeneration followed during which mainly new Tethyan faunal elements immigrated to the Eiberg Basin.

A broad spectrum of marine invertebrate groups is recorded, although brachiopods are rare. Macrofossils (Fig. 11.1-11.6) are represented by biostratigraphically (ammonites) as well as palaeoecologically important groups (bivalves, echinoderms). Microfossils (Figs. 11.7-11.11, 12, 13) constitute a major part of the calcareous biomass except for the Schattwald Beds where only a depauperate foraminifer record is present. Ostracods (Fig. 15) are usually less frequent than foraminifers. Calcareous nannofossils (Figs. $16,17)$ are present in many samples, though they are unfortunately very rare and extremely small. Most samples were rich in well preserved palynomorphs (Figs. 23-26), which have a palynomorph colour of 1-2 on the thermal alteration scale (TAS) of Batten (2002). The microfloral record across the Triassic-Jurassic boundary is characterized by significant quantitative changes in the terrestrial and marine components of the assemblages with a few notable palynostratigraphic events, which are very similar to those described from the Tiefengraben section in the eastern part of the Eiberg Basin (Kürschner et al., 2007).

\section{Macrofossils}

a) Ammonites (cf. Hillebrandt and Krystyn, 2009) (Figs. 10, 11, 22)

Low ammonite diversity, sporadic occurrence of determinable specimens and restriction to certain levels are characteristics of the sections, though shell fragments were frequently found in samples for micropalaeontological studies (Figs. 12, 13). The limestones of the upper Eiberg Member contain relatively common fragments of Choristoceras, but the last pure limestone bed shows only crosssections of unextractable specimens. Rare, compressed and flattened Choristoceras marshi (Fig. 11.6) are found in the uppermost part of the T-Bed, representing the last occurrence not only of the genus Choristoceras but of Triassic ammonoids and conodonts at all in the section. Choristoceratids are the only common cephalopods in the Eiberg Member. The reported presence of another group (Rhaetites, a gigantogaleat arcestid) in the T-Bed of the Möserer Alm near Steinplatte (Bökenschmidt and Zankl, 2005) is thus an extremely rare and sensational exception.

Ammonite level (2), located from 5.8-6.2 $\mathrm{m}$ above bed $\mathrm{T}$ at the Kuhjoch West section, contains mostly flattened and small (rarely

$>2 \mathrm{~cm}$ ) specimens, which are easily visible due to their white aragonitic shell. Rare, originally pyritic and now mostly limonitized, undeformed phragmocone specimens allow an exact illustration of the cross-section and the suture line. The specimens belong to an involute species of Psiloceras with predominating psiloceratid characters (mainly inner whorls with well developed "Knötchenstadium"). The suture line with a lituid internal lobe is evolutionarily still related to Triassic phylloceratids. Other Triassic phylloceratid features are the high ovate whorl section with well developed umbilical wall and similar growth lines.

The Alpine specimens were originally determined as $P$. cf. spelae 


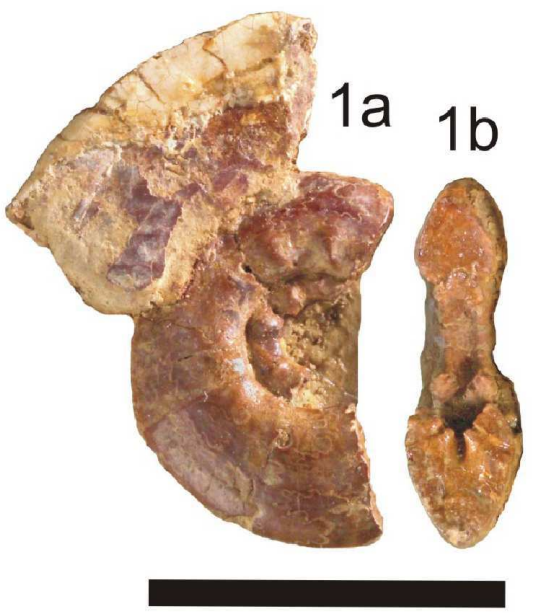

$1 \mathrm{~cm}$

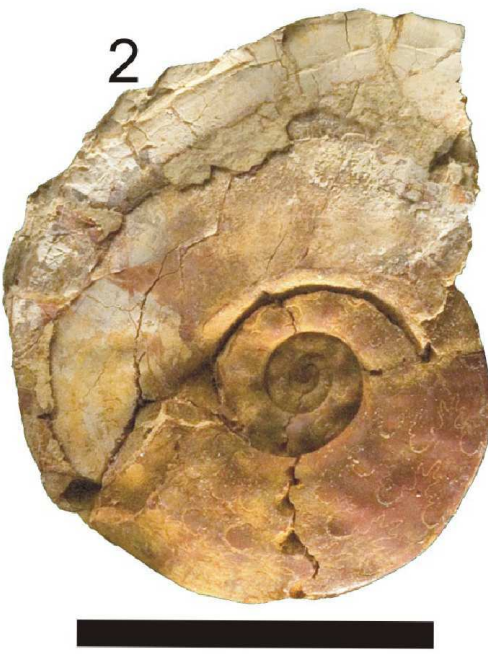

$1 \mathrm{~cm}$
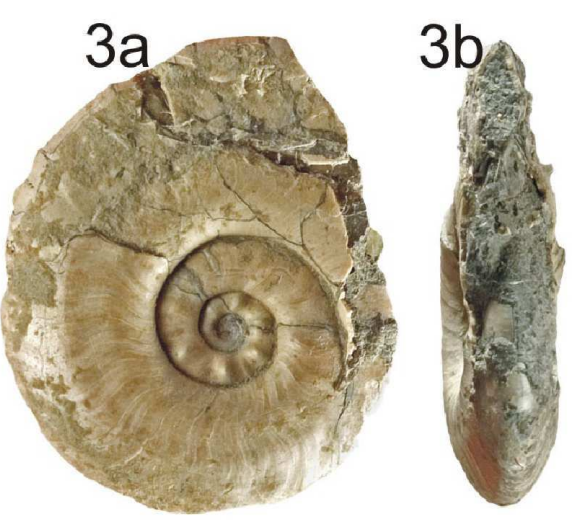

$1 \mathrm{~cm}$
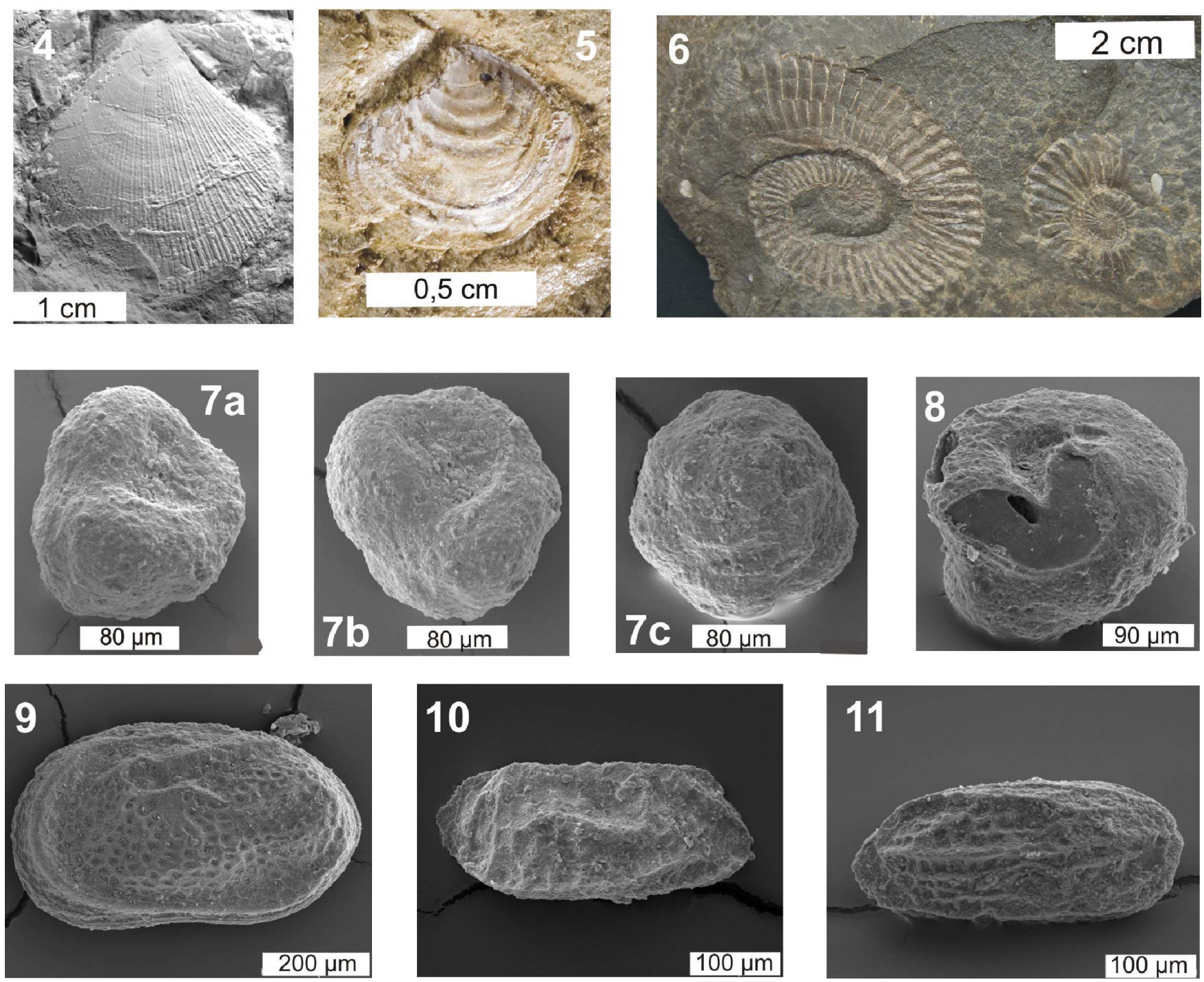

Figure 11. Important guide fossils from the Triassic-Jurassic boundary of GSSP Kuhjoch. 1-3: Psiloceras spelae tirolicum Hillebrandt and Krystyn, 1a,b, 2: Kuhjoch, 3: Hochalplgraben; 4: Agerchlamys sp., Hochalplgraben; 5: Astarte sp., Kuhjoch, spelae horizon; 6: Choristoceras marshi Hauer, Kuhjoch, top T bed; 7a,b,c: Praegubkinella turgescens Fuchs, Kuhjoch, spelae horizon; 8: ?Reinholdella sp., Kuhjoch, cf. pacificum horizon; 9: Cytherelloidea buisensis Donzr, lv, Kuhjoch, spelae horizon; 10: Eucytherura sagitta Swift, rv, Hochalplgraben, cf. pacificum horizon; 11: Eucytherura n.sp., lv, Kuhjoch, latest Rhaetian. rv = right valve, lv = left valve. 
(Fig. 8 in Hillebrandt et al., 2007), because only one specimen was figured from Nevada, which does not show all the characters present in P. spelae from the Alps. Moreover, the variability of the Alpine species was not well known. A later published specimen of $P$. spelae from Nevada shows the end of the body chamber with a sculpture comparable with that in $P$. spelae from the Alps. In the meantime $P$. spelae from Nevada and the Alps could be compared directly. J. Guex and the first author (as well as G. Bloos, Stuttgart) concluded that $P$. spelae from Nevada and from the Alps belong to the same species but can be distinguished as regional subspecies: Psiloceras spelae spelae and Psiloceras spelae tirolicum (Figs. 11.1-3). The two subspecies are closely related phylogenetically and in time. They characterize the ammonite biohorizon of $P$. spelae, which is the earliest ammonite biohorizon of Jurassic aspect. A detailed description on the basis of more than 100 specimens is found in Hillebrandt and Krystyn (2009). The new subspecies has a nodose stage very similar to that of $P$. spelae spelae. $P$. spelae spelae has more sculptural elements (nodes) per whorl (12) than $P$. spelae tirolicum (7 to 8 ) and the sculpture with elongated nodes persists up to an umbilical diameter of $3.5 \mathrm{~mm}$ ( 2.0 to $2.4 \mathrm{~mm}$ in P. spelae tirolicum). The original whorl section of $P$. spelae spelae is insufficiently known, so an original subtriangular whorl section cannot be excluded. The suture line, the beginning of the nodose stage and the innermost whorls of $P$. spelae spelae are also unknown. The differences between both subspecies are probably caused by palaeobiogeographic separation. Korte and Kozur (2011) postulate a $100 \mathrm{ky}$ younger age of $P$. spelae tirolicum against $P$. spelae spelae from Nevada on the basis of an extremely fine-tuned C-isotope correlation between NYC (New York Canyon) and Kuhjoch. In our opinion, this implied accuracy and correlation are not justified. Co-occurrence of $P$. spelae spelae and $P$. cf. tilmanni in Nevada more likely points to the opposite, i.e. a slightly younger age of the Nevadan occurrence because $P$. cf. tilmanni appears in the NCA above $P$. spelae tirolicum.

Anaptychi of $P$. spelae tirolicum and a fragment of Togaticeras cf. goisernense (Hillebrandt and Krystyn, 2009, fig. 10.16) are also known. A small specimen (diameter $1 \mathrm{~cm}$ ) (Kuhjoch West section) of a phylloceratid was found in 2008 by Stefan Gräbenstein (Bodelshausen, Germany). As the specimen is more involute than Triassic phylloceratids and the cross section and involution is similar to that of $P$. chilense from the Hettangian of South America it is determined as Phylloceras cf. chilense. Similar specimens are also recently found in the spelae horizon of the Zlambach area.

Ammonites from level (3a) (Kuhjoch West section) have been detected in the residue of a washed sample containing 20 limonitic casts of inner whorls $(<1.7 \mathrm{~mm})$, One compressed specimen $(3 \mathrm{~mm})$ and a whorl fragment (Wh $2.5 \mathrm{~mm}$ ) with suture lines can be placed within the P. tilmanni group (Hillebrandt and Krystyn, 2009, figs. 13.1-4). A similar level (3b) was found in the Ochsentaljoch section $3.5 \mathrm{~m}$ below ammonite level (4) (Figs. 9, 10).

Ammonite level (4), located $4 \mathrm{~m}$ above level (3a) and $6 \mathrm{~m}$ above ammonite level (2), has yielded several shell fragments and one poorly preserved specimen in the Kuhjoch section. Four specimens from the Hochalplgraben section are illustrated in Hillebrandt and Krystyn (2009) (figs. 10.11-14). Two tiny juveniles and two larger forms (up to $15 \mathrm{~mm}$ in diameter) with relatively wide umbilicus are determined as Psiloceras cf. pacificum, a species described from Nevada (North America) (Guex, 1995) and also found in Peru (South America) (Hillebrandt, 2000a).

Ammonite level 4a (Hochalplgraben) yielded a fragment (whorl height $16 \mathrm{~mm}$, whorl width $10 \mathrm{~mm}$ ) of a Psiloceras with a smooth body chamber (Psiloceras sp. A in Hillebrandt and Krystyn, 2009, figs. $5,11.6 \mathrm{a}, \mathrm{b})$ which probably belongs to the P. erugatum/ minillaensis group.

In ammonite level 4b (Rissbach section across Hinterriß) Psiloceras cf. planorbis and a new species of Psiloceras (possibly related to Psiloceras spelae) were found in a limestone bed at the boundary between the Tiefengraben Member and the Breitenberg Member.

Ammonite level (5), rich in ammonites in the Kuhjoch section, follows $12 \mathrm{~m}$ above level (4) near the top of the Kendlbach Formation. A single limestone bed here contains large sized Psiloceras calliphyllum, P. costosum and P. naumanni (Fig. 10). The level is condensed, containing species of at least 2 ammonite horizons of the Calliphyllum Zone.

Ammonite level (6) is a limestone bed (18 to $20 \mathrm{~cm}$ thick), with rare ammonites in the Kuhjoch section, contains Alsatites cf. liasicus, Megastomoceras megastoma, and Storthoceras frigga of the Middle Hettangian Megastoma Zone (Hillebrandt and Kment, 2011).

Ammonite level (7) is in a limestone bed (20 cm thick) and the uppermost bed of the Breitenberg Member in the Kuhjoch section. It contains rare ammonites, Alpinoceras haueri of the Late Hettangian Marmorea Zone (Hillebrandt and Kment, 2011).

\section{b) Bivalves (written by C. McRoberts) (Figs. 11-13)}

Bivalves occur throughout the GSSP interval at Kuhjoch and nearby sections at Ochsentaljoch. From Kuhjoch west, the uppermost Kössen carbonates of the Eiberg Member (below the T-Bed sensu McRoberts et al., 2012) yielded the typically Triassic bivalves Cassianella sp. and Lyriochlamys valoniensis. The T-Bed itself and the lower centimetres of the Tiefengraben Member contain Agerchlamys textoria and rare Pseudolimea cf. hettangiensis that are concentrated in the bituminous layer at the top of the T-Bed. Tens of centimetres above the T-Bed and into the lower Tiefengraben Member occurs Cardinia hybrida. The grey marls of the Tiefengraben Member also provide at different levels small nuculids and different species of Cardinia: C. cf. listeri and Astarte sp. (Fig. 11.5) were found in ammonite level (2) and Cardinia cf. ingens $7.45 \mathrm{~m}$ above the T Bed. The residues of washed microfossil samples often contain juvenile specimens (mostly steinkerns) or fragments of bivalves, mostly pectinids and nuculids (Figs. 12, 13). Higher in the sequence, the first limestone bed, $4 \mathrm{~m}$ above ammonite level (4) in the Ochsentaljoch section, yielded Modiolus, Liostrea and additional examples of Agerchlamys (Fig. 11.4).

\section{c) Gastropods and scaphopods (written by A.v. Hillebrandt)}

Tiny and juvenile gastropods (mainly steinkerns) were often found in the residue of washed samples for microfossils (Figs. 12, 13), but determinable specimens are very rare. Fragments of scaphopods appear in the residue of some samples.

\section{d) Brachiopods (written by A. Tomãsových)}

A last Triassic brachiopod, the giant spiriferid Oxycolpella oxycolpos, occurs in the bed below as well within the T-Bed. Brachiopods are rare in the lower part of the Tiefengraben Member and restricted to a few beds. A layer with compressed multicostate 
rhynchonellids occurs in the lower part of the Schattwald Beds of the Kuhjoch section. Although these specimens are the stratigraphically earliest (after the last Choristoceras) rhynchonelliformean brachiopods found in the Eastern NCA, their taxonomic relation is uncertain owing to their poor preservation.

The biomicritic limestone bed in the Ochsentaljoch section, about $4 \mathrm{~m}$ above the level with Psiloceras cf. pacificum in the upper part of the Tiefengraben Member, contains well-preserved rhynchonellids of the exclusively Hettangian species Tetrarhynchia inopinata (Siblík, 1999). This species is also abundant in the Breitenberg Member of the Hochleitengraben section (type locality, Siblík, 1999; Tomãsových and Siblík, 2007). It probably preferred low-energy habitats below storm wave base, and was able to tolerate some input of terrigenous supply. Tetrarhynchia inopinata is thus the first rhynchonelliformean brachiopod that colonized sea-floors during deposition of the Tiefengraben Member after the T-J boundary because an increase in abundance and diversity of Hettangian brachiopods in the Eastern
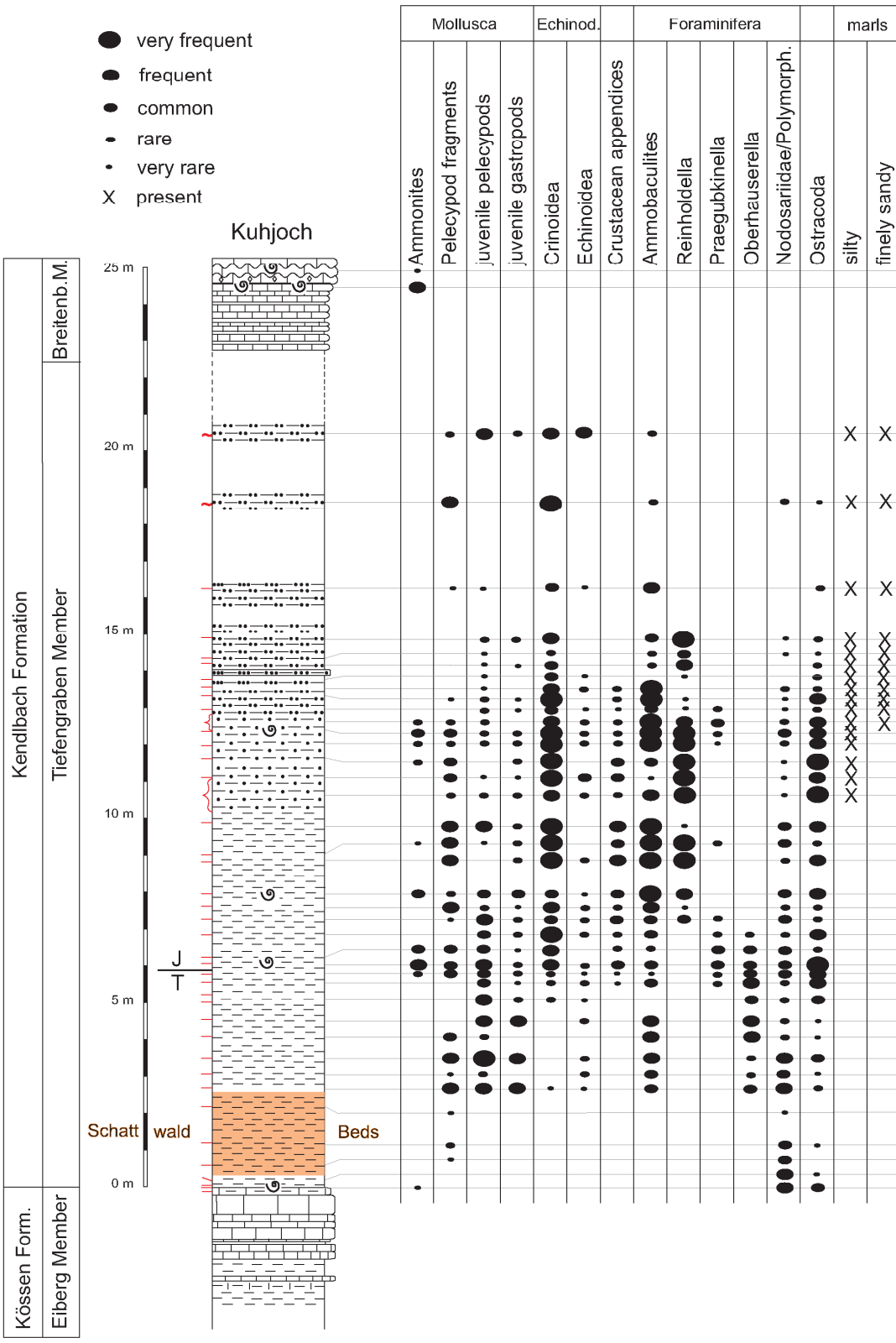

Figure 12. Occurrences and relative abundances of Microfossils from Kuhjoch West section.
NCA coincides with the onset of the Breitenberg Member (Tomãsových and Siblík, 2007). Tetrarhynchia inopinata represents the earliest and endemic species of the genus Tetrarhynchia, which was a common member of benthic communities in the Early and Middle Jurassic. Rhaetian tetrarhynchiids do not occur in the western Tethys, and ancestors of Tetrarhynchia inopinata thus probably migrated into the western Tethys from adjacent biogeographic regions. The specimens sampled in the Ochsentaljoch section attain 10-16 $\mathrm{mm}$ in length, $10-18 \mathrm{~mm}$ in width, and 6-14 $\mathrm{mm}$ in thickness. Dorsobiconvex shells possess incipient planareas, suberect/erect beak, relatively sharp beak ridges, hypothyrid/submesothyrid foramen, relatively thick deltidial plates, and 8-12 relatively rounded costae that reach to the umbo in both valves and do not show any bifurcation. The anterior margin is rounded, but rarely flattened. Smaller and larger specimens differ highly in shell shape and convexity because shell width and thickness increase in size more rapidly than shell length. Internal structures of two sectioned specimens show internal shell thickenings in the umbonal parts of the dorsal valve, presence of massive median septum connected with hinge plates, and enclose a markedly pronounced notothyrial cavity.

The smooth-shelled terebratulid Lobothyris delta is found in the lower part of the Breitenberg Member and is frequent in one limestone bed of the Schlossgraben section. Lobothyris became a numerically dominant brachiopod in carbonate-rich environments of the Eastern NCA during the deposition of the Breitenberg Member and its appearance marks the onset of recovery phase of brachiopod distribution patterns to pre-extinction levels (Siblík, 1993; Tomãsových and Siblík, 2007). Members of this genus also form Hettangian shell beds in palaeobiogeographically-adjacent regions of the Western Carpathians (Tomãsových, 2008).

\section{e) Echinoderms (written by M. Simms and in part by A.v. Hillebrandt)}

Crinoid ossicles occur in the washed residue of many samples (Figs. 12, 13); fragments of echinoids are less frequent (Figs. 12, 13). Holothurian ossicles are found in some samples as well as crinoid ossicles, which can be very frequent (Figs. 12,13). A $1 \mathrm{~cm}$ thick layer in the upper part of ammonite level (2) contains in the Hochalplgraben section nearly exclusively crinoids. Connected (up to $1 \mathrm{~cm}$ ) columnals of crinoids are also frequent at ammonite level (2) with $P$. spelae tirolicum of Kuhjoch East section (GSSP).

Most ossicles are from the cirri with a few hooked terminal cirral ossicles determined so far as isocrinid. The bulk of the material comprises mainly columnals and a few brachials of isocrinids. Different types of columnals (nodals, internodals and infranodals) are found. From the relative abundances of nodal versus internodal and infranodal columnals it is estimated that the number of columnals per noditaxes averages about 6 or 7 , although the longest pluricolumnal recovered has just 5 columnals. An apparently identical isocrinoid is found in the Larne section in Northern Ireland, 


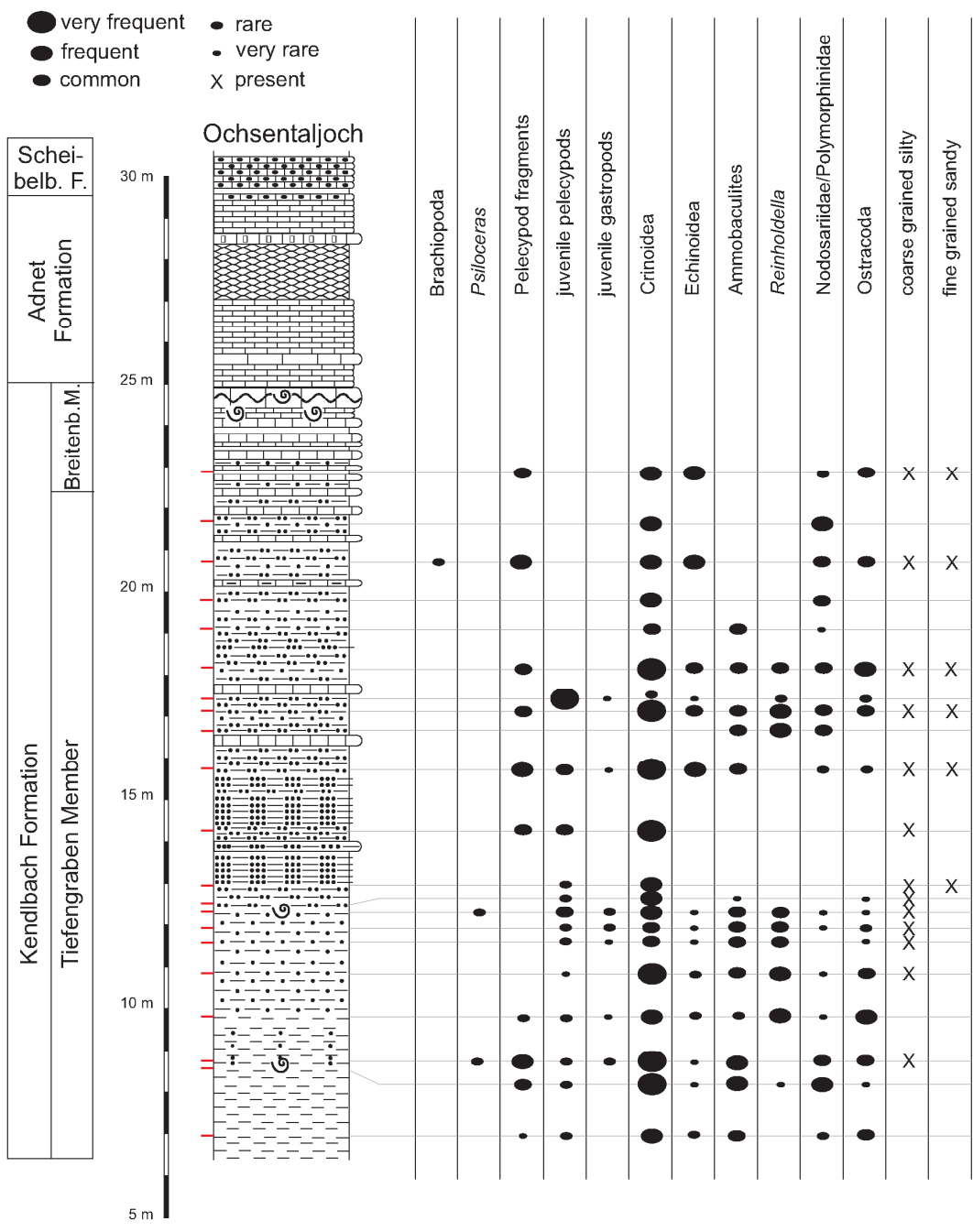

Figure 13. Occurrences and relative abundances of Microfossils from Ochsentaljoch section.

$2.5 \mathrm{~m}$ below the first Psiloceras erugatum (first Psiloceras in Great Britain). Columnal morphology and the number of columnals per noditaxis for both the Kuhjoch and Larne material corresponds closely to Isocrinus angulatus (Oppel). This species in the UK appears to range from the Pre-Planorbis Beds into at least the lower part of the Angulara Zone.

Spines of echinids can be frequent in the uppermost part of the Tiefengraben Member.

\section{Microfossils}

50 microfossil samples have been studied from the Kuhjoch West section, 30 from the Kuhjoch East section and 21 from the Ochsentaljoch section, with various fossil groups represented. Ossicles of Echinodermata are often more frequent than other microfossils (Figs. 12, 13), foraminifers usually outnumber ostracods. Small appendices of crustaceans can be common in some samples (Figs. 12, 13). Radiolaria are extremely rare.

a) Foraminifers (written by A.v. Hillebrandt) (Figs. 12-14)

\section{(1) Kuhjoch sections (Fig. 12)}

Most observations were made at section Kuhjoch West. The less weathered marls of this section mostly contain better preserved foraminifers than those from Kuhjoch East. Black and grey marls 2.5 and $1 \mathrm{~m}$ below the uppermost beds of Kössen limestones (Kuhjoch East) yielded only small sized Trochammina, Ammodiscus and polymorphinids (limonitic casts). A weathered sample (Kuhjoch East) from the basal part of the T-Bed contains a diverse fauna of Nodosariidae with few Textulariina. This fauna is typically Rhaetian. The diversity decreases in the upper part of the T-Bed towards the end-Triassic mass extinction (see also Hillebrandt and Kment, 2011, Fig. 2). The beds between the Top-Kössen and the Schattwald Beds are characterized by small, mostly compressed, coarsely agglutinated Trochammina and an impoverished fauna of nodosariids often characterized by a large species of Marginulinopsis (Kuhjoch West).

Hippocrepina (a finely agglutinated siliceous foraminifer with simply constructed test) dominates the Schattwald Beds of the Eiberg Basin and is accompanied by compressed Trochammina and an impoverished fauna of nodosariids (especially Marginulinopsis). The predominance of Hippocrepina points to unfavourable ecologic conditions during "Schattwald time" ( $100 \mathrm{kyr}$ ) amongst others unsuitable for the segregation of calcitic test due to a $\mathrm{CaCO}_{3}$ precipitation crisis as proposed by McRoberts et al. (2012). Hippocrepina and compressed Trochammina still dominate the first grey marl with thin red layers at the transition from the Schattwald Beds to the Tiefengraben Member s.str. of Kuhjoch East.

Large Ammobaculites (species similar to that of the Kössen Fm.) are common to frequent in many samples of the marls above the Schattwald Beds.

Compressed Trochammina and tiny, uncompressed Trochammina are dominant in the lower part of the grey marls above the Schattwald Beds. Ammodiscus and Glomospira are rare and in some samples small, attached Ammodiscidae are common.

Small Nodosariidae and Polymorphinidae are mostly rare in the lower part of the Tiefengraben Member, Polymorphinidae more frequent than Nodosariidae, while the latter become more frequent from ammonite level (2) upwards. Well preserved, limonitic casts of Polymorphinidae are found in weathered samples of Kuhjoch East. Lenticulina can be the dominating nodosariid genus in the upper part of the Tiefengraben Member. Robertinina are represented by 3 genera (Figs. 12-14): Oberhauserella mostly is common; Praegubkinella (Fig. 11.7) may be common in the intervals around the ammonite horizons; and Reinholdella (Fig. 11.8) is very frequent in the middle part of the Tiefengraben Member. The specimens are usually preserved with aragonitic shell. A characteristic increase in size and evolution takes place from Oberhauserella (diameter $\sim 0.06$ to $0.12 \mathrm{~mm}$ ) to Praegubkinella $(\sim 0.15$ to $0.2 \mathrm{~mm})$ and Reinholdella $(\sim 0.2$ to 0.3 $\mathrm{mm}$ ) (Hillebrandt, 2008).

\section{(2) Ochsentaljoch section (Fig. 13)}

Ammobaculites is common to frequent in most samples but disappears in the uppermost samples. Glomospira and attached 

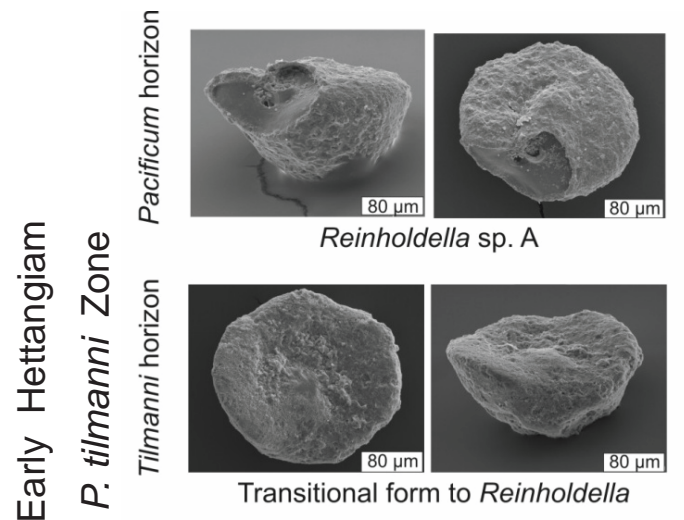

Reinholdella sp. A

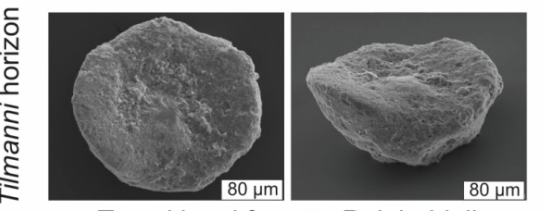

Transitional form to Reinholdella

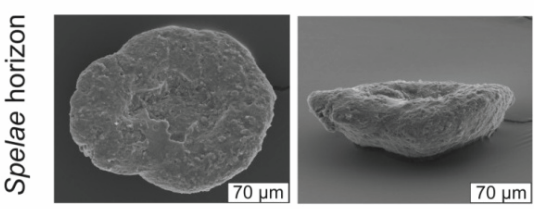

Oberhauserella cf. subcircularis
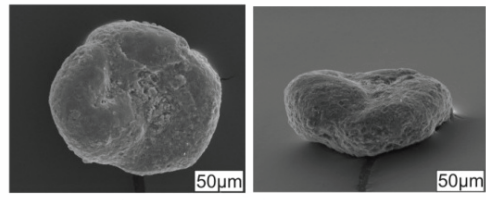

Oberhauserella cf. subcircularis

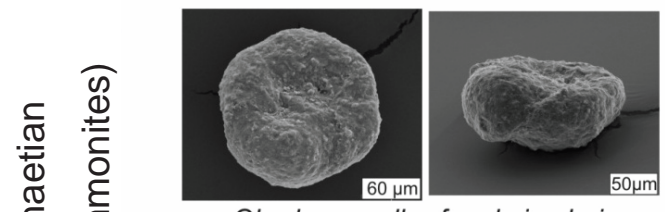

Oberhauserella cf. subcircularis
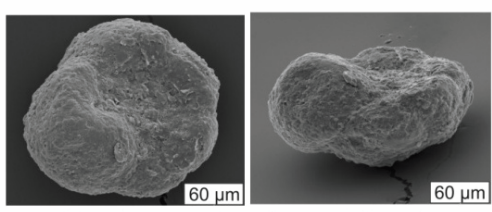

Oberhauserella cf. quadrilobata
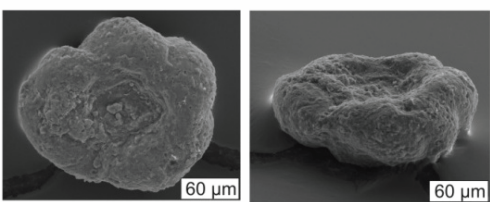

Oberhauserella cf. quadrilobata

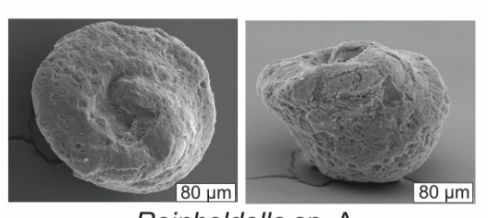

Reinholdella sp. A

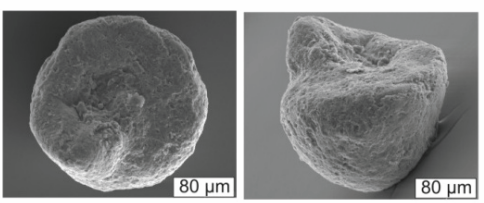

Transitional form to Reinholdella

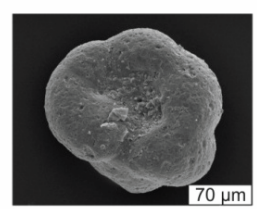

Praegubkinella turgescens
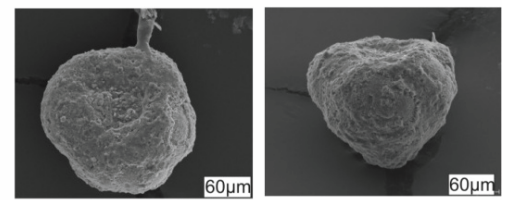

Praegubkinella cf. turgescens

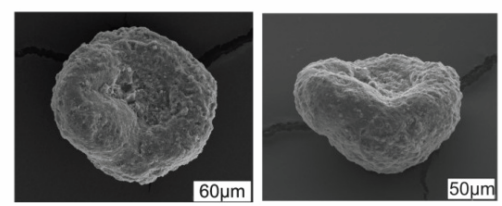

Oberhauserella alta

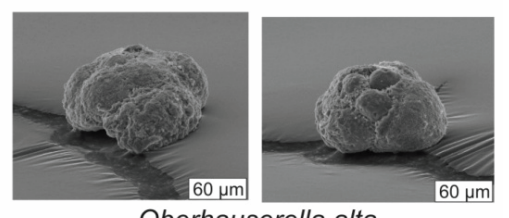

Oberhauserella alta
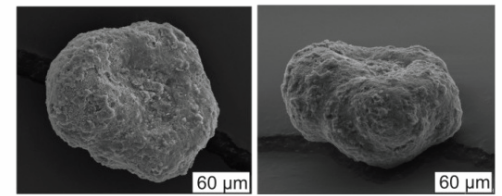

Oberhauserella alta

from adjacent localities of the Karwendel Mountains are summarized. The earlier work (Hillebrandt and Urlichs, 2008) is now updated based on additional material. From the uppermost Eiberg Member to the Tiefengraben Member (Late Rhaetian-Early Hettangian), three different groups of ostracods are distinguishable by their stratigraphic ranges (Fig. 15):

1. The dark marls 3.8-4.0 m below the top of the Eiberg Member (late Marshi Zone) contain at Kuhjoch a high-diverse Rhaetian ostracod fauna comprising 30 species (Fig. 15: species restricted to the Rhaetian are marked in red). The following rare species are missing above this layer: Citrella? ampelsbachensis, $C$ ? bairdiiformis, Monoceratina? lobitzeri, and Triebacythere loferensis. Other species range somewhat higher up within the Eiberg Member: Bairdia subsymmetrica, Bairdia sp. A, Cytherelloidea plana, Eucytherura norica, Kerocythere mostleri (at Schlossgraben), Nodobairdia reticulata, Parariscus? pygmaeus, and Triebacythere ampelsbachensis. Further species Bairdiacypris sp. B, Signohealdia robusta, S? rotunda, and Tuberoceratina fortenodosa continue at Kuhjoch to the base of the T-Bed, Kerocythere hartmanni, Nodobairdia alpina, and at Schlossgraben $N$. dentata. The earlier disappearance of some taxa at Kuhjoch may be caused by unfavorable preservation conditions, because merely lowdiverse faunas consisting of preferably thickly shelled, and corroded ostracods occur there in thin marl beds. Additional species persist at Schlossgraben even to the upper part of the TBed: Dicerobairdia ornata, Lobobairdia triassica, Ogmoconchella serratostriata, and Pseuodomacrocypris sp. A. Together with Choristoceras marshi (= ammonite horizon 1 in Fig. 15), merely Ogmoconcha trigonia, Ogmoconchella bristolensis, O. martini, and Torohealida amphicrassa continue into the thin, black layer at the top of the T-Bed at Schlossgraben. The bulk of the Rhaetian species disappeared from the bottom to the top of the T-Bed. Consequently, the end-Triassic mass extinction took place within this bed. Altogether

Figure 14. Stratigraphy and Evolution of Robertinina, in the western Karwendel Syncline (Hillebrandt 2010).

Ammodiscidae occur in some samples. Trochammina is restricted to the lowest samples. Nodosariidae and Polymorphinidae are very rare to frequent in the lower and middle part of the section. Polymorphinidae can be more frequent than Nodosariidae in the lower part. Lenticulina is the most frequent nodosariid genus in the upper part, mostly together with Lingulina tenera. Reinholdella is common to frequent in many samples and disappears (like Ammobaculites) in the upper samples.

\section{b) Ostracods (written by M. Urlichs) (Fig. 15)}

The occurrences of ostracods from the GSSP Kuhjoch West and
27 of 45 Rhaetian species (= $60 \%$ of the Rhaetian ostracod species) recorded from outcrops of the Karwendel Mountains disappeared, and the ostracod fauna of the uppermost Rhaetian becomes poor and exhibits low diversity above the T-Bed and below the Schattwald Beds. Only Eucytherura schulzi and Ogmoconchella bristolensis have been recorded from this interval. The overlying Schattwald Beds are barren in ostracods, because they were obviously deposited in an environment, which is not normal marine. A high $\mathrm{CO}_{2}$ content in the sea water probably hindered the precipitation of $\mathrm{CaCO}_{3}(\mathrm{McRoberts}$ et al., 2012).

2. The second group (marked in black in Fig. 15) consists of ostracod taxa, which occur already in the late Marshi Zone and 


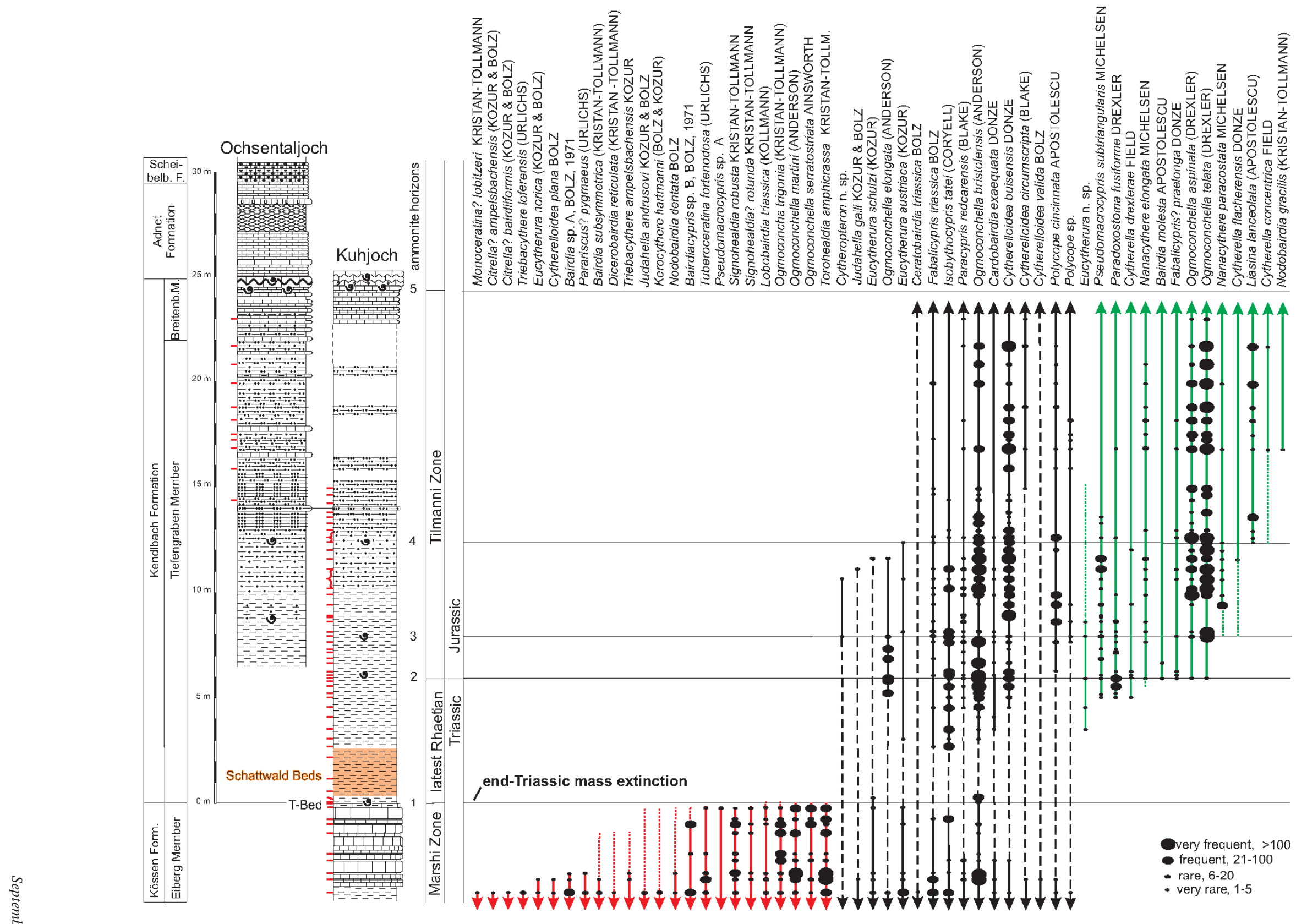

Figure 15. Stratigraphic range chart of ostracods at Kuhjoch West and Ochsentaljoch sections (red: Triassic species; black: Triassic-Jurassic species; green:Jurassic species; ammonite levels : 1 = Choristoceras marshi, 2 = Psiloceras spelae tirolicum, 3 = Psiloceras ex gr. P. $c f$. tilmanni, 4 = Psiloceras $c f$. pacificum). 
reappear either above the Schattwald Beds in the latest Rhaetian or somewhat later within the Tilmanni Zone (earliest Hettangian). Many of them cease at Kuhjoch in this zone Cytheropteron n. sp., Eucytherura austriaca, Eu. schulzi, Judahella galli, Ogmoconchella elongata and at Hochalplgraben Eucytherura sagitta (Fig. 11.10), Lutkevichinella hortonae, and Procytherura nannodes. Other species continue into younger zones, at least into the Calliphyllum Zone: Cardobairdia exaequata, Ceratobairdia triassica, Cytherelloidea buisensis (Fig. 11.9), C. circumscripta, C. valida, Fabalicypris triassica, Isobythocypris tatei, Ogmoconchella bristolensis, Paracypris redcarensis, Polycope cincinnata, and Polycope sp.

3. The third group consists of strictly Jurassic ostracod taxa (marked green in Fig. 15). At Kuhjoch, the earliest Jurassic species occur in the Tiefengraben Member 1.0-2.4 m below the first occurrence of Psiloceras spelae tirolicum (= ammonite horizon 2 in Fig. 15 = base of the Tilmanni Zone): Cytherella drexlerae, Eucytherura n. sp. (Fig. 11.11), Nanacythere elongata, Paradoxostoma fusiforme, and Pseudomacrocypris subtriangularis. Other Jurassic species appear for the first time together with Psiloceras spelae tirolicum: Bairdia molesta, Fabalicypris praelonga, Ogmoconchella aspinata (=O. ellipsoidea), and O. telata . Further Jurassic species emerge at the Hochalplgraben in the horizon with Psiloceras ex gr. P. tilmanni (= ammonite horizon 3 in Fig. 15): Nanacythere paracostata and Cytherella flacherensis. Additional species appear together with Psiloceras cf. pacificum (= ammonite horizon 4 in Fig. 15) for the first time: Liasina lanceolata (at Kuhjoch), Kinkelinella sp., Cytherella concentrica (at Hochalplgraben), and above this horizon Acratia sp. B, Nodobairdia gracilis, and Pustulobairdia sp. A. (at Hochalplgraben).

In summary, some rare ostracod species disappeared already during the late Marshi Zone, and many Rhaetian ostracods became extinct at the base of the T-Bed, and a few species within or at the top of this bed. The ostracod fauna from the Tilmanni Zone (Early Hettangian) of the Karwendel Mountains comprises Rhaetian holdovers and Jurassic immigrants. A re-elaboration of Rhaetian ostracods during the Early Hettangian appears unlikely, because some species originally described from the Rhaetian occur also in the Middle and Late Hettangian (e.g. Harloff and Jäger, 1994: Cytherelloidea valida from the Calliphyllum Zone and Ceratobairdia triassica from the Megastoma Zone). The recovery of Jurassic ostracods took place gradually within the Tilmanni Zone, together with the subsequent appearances of the three ammonite species recorded above (= ammonite horizons 2-4 in Fig. 15). The bulk of the Jurassic ostracod species appeared somewhat below or together with Psiloceras spelae tirolicum and some others together with Psiloceras ex gr. P. tilmanni or later together with Psiloceras cf. pacificum.

The significance of the stratigraphically important ostracod species is discussed in the biostratigraphy chapter.

\section{c) Conodonts (written by L. Krystyn)}

Since the pioneering study of Mostler et al. (1978) conodonts are known to occur widely in the Kössen Formation of the NCA. They are more common in the calcareous basinal facies of the Eiberg Member (Golebiowski, 1986) and have also been documented from the uppermost Triassic part of the Kendlbach section (Krystyn, 1980). In Kuhjoch, repeated dissolution $(6 \mathrm{~kg})$ of the last autochthonous limestone layer (sample KJ-2) of the Kössen Formation has produced a relatively numerous and diverse fauna dominated by specimens of the genus Misikella (individual numbers in brackets): $M$. posthernsteini (26), M. ultima (2), Zieglericonus rhaeticus (2), and Neohindeodella sp. (4). Of these forms, M. ultima is the name bearer of the topmost Triassic conodont zone as found in Hungary (Kozur and Mock, 1991; Palfy et al., 2001), Turkey (Gallet et al., 2007) and Austria. Kozur and Mock (1991) distinguished above the ultima zone another short conodont interval (Neohindeodella detrei zone), which eventually could correspond to the topmost T-Bed of the Kössen Formation in Kuhjoch. This bed seems due to its high marl and silt content unsuitable for conodonts and has not been investigated. A large sample $(8 \mathrm{~kg})$ from a more calcareous counterpart of T-Bed on the Steinplatte slope (Tyrol) has produced a tremendous amount of insoluble residue but no conodonts.

d) Calcareous Nannofossils (written by P. Bown) (Figs. 16, 17)

Twenty-one samples were examined from the Kuhjoch section and all but four were nannofossiliferous. The nannofossil assemblages

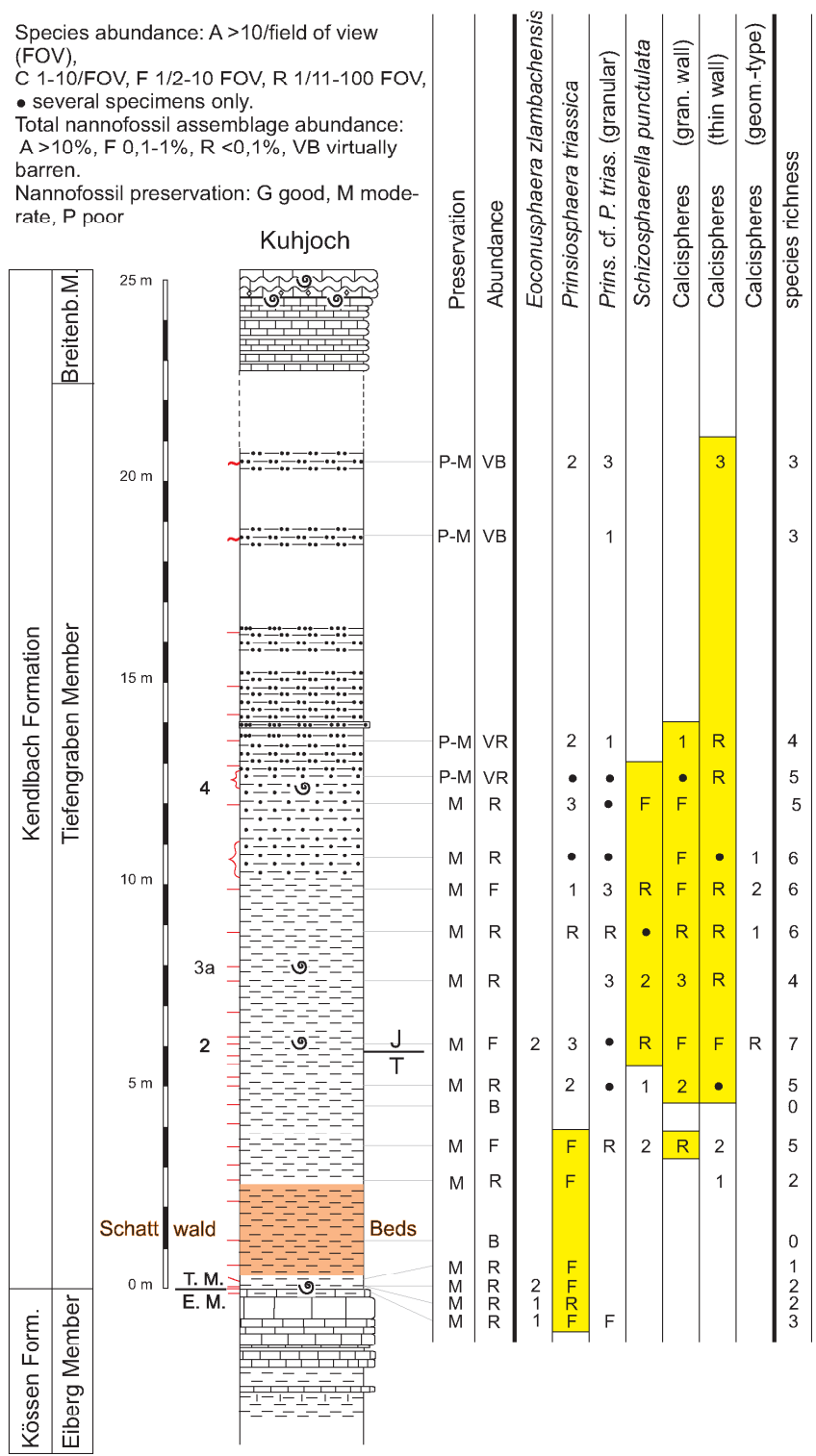

Figure 16. Stratigraphic range chart of calcareous nannofossils from Kuhjoch West. 


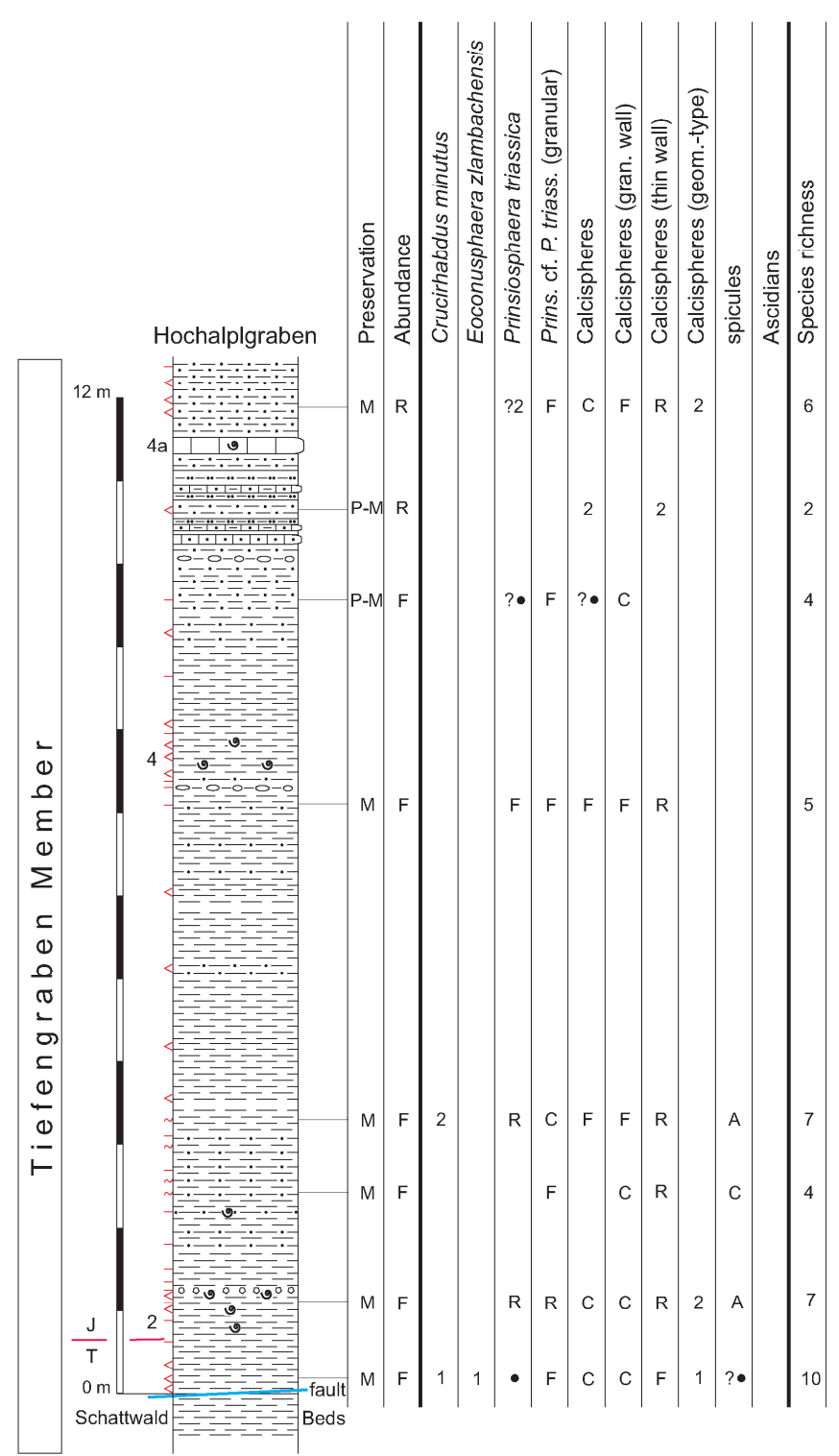

Figure 17. Distribution of calcareous nannofossils from Hochalplgraben section.

are generally rare to frequent, of low diversity and poorly-moderately preserved. The lowermost samples (Fig. 16, 0-3.6 m) are dominated by Prinsiosphaera triassica but the section probably lies above the LO (last occurrence) of Eoconusphaera zlambachensis (the few specimens seen are most likely reelaborated). At the boundary interval $(\sim 6 \mathrm{~m})$ there is a switch in dominance from $P$. triassica to calcispheres and Schizosphaerella punctulata. The FO (first occurrence) of $S$. punctulata may be coincident with the boundary level. We hope to refine the position of these bio-events with further high-resolution sampling and quantitative assemblage data. Both the LO of $P$. triassica and the FO of $S$. punctulata may be extremely useful boundary indicators as they are common, robust and globally distributed species.

\section{e) Palynomorphs (written by W.M. Kürschner, N.R. Bonis, and M.A.N. Schobben) (Figs. 23-26)}

In general, pollen and spore assemblages from the Kössen Formation are dominated by Classopollis meyeriana and C. torosus accompanied by Ovalipollis pseudoalatus, Rhaetipollis germanicus and Ricciisporites tuberculatus. Marine palynomorphs such as dinoflagellate cysts Rhaetogonyaulax rhaetica and Dapcodinium priscum and some acritarchs (e.g. Microhystridium) are present. The palynomorph assemblages from the topmost bed of the Kössen Formation (black shale of top T-bed) are characterized by peak abundances of prasinophytes, particularly Cymatiosphaera polypartita. The rather monotonous sporomorph assemblages from this interval are dominated by C. meyeriana and Porcellispora longdonensis. Sporomorph assemblages from the Schattwald Beds are characterized by an increase in Polypodiisporites polymicroforatus, Deltoidospora spp. and Calamospora tener, while C. meyeriana declines. Rhaetipollis germanicus disappears in the lower part of the Schattwald Beds, while O. pseudoalatus has its highest appearance at the top of the Schattwald Beds. Algal remains in the Schattwald Beds are mainly represented by Botryococcus and Tasmanites, while dinoflagellate cysts are rare and Rhaetogonyaulax rhaetica disappears. Of biostratigraphic value is the lowest occurrence of Cerebropollenites thiergartii and Ischyosporites variegatus immediately above the Schattwald Beds and ca. $3 \mathrm{~m}$ below the entry level of $P$. spelae. For further discussion of the palynological results see paragraphs below.

\section{Sediment diagenesis (written by A.v. Hillebrandt, L.} Krystyn, and W.M. Kürschner)

At the Kuhjoch section no significant alteration is observable. Ammonites, bivalves, and aragonitic forams (in part hollow) are preserved with an aragonitic shell. There are absolutely no signs of regional or local metamorphism of the rocks (Kuhjoch, Hochalplgraben, Schlossgraben and also Tiefengraben and Kendlbach). From the preservation of palynomorphs, notably the colour, it is evident that this material was never heated above about $50^{\circ} \mathrm{C}$ (see also Kürschner et al., 2007). Conodonts also show a low CAI 1 value.

$\overline{\text { Geochemistry (written by M. Ruhl, W.M. Kürschner and }}$ S. Richoz)

Carbon isotopes of bulk sedimentary organic matter have been studied by Ruhl et al. (2009) as well as carbon-isotopes of selected micrite and shells (this study). In addition, compound-specific Cisotope measurements (n-alkanes) have been carried out (Ruhl et al., 2011). A clay mineralogy/XRD stratigraphy has been published for the coeval Kendlbach section by Zajzon et al. (2012) and Palfy and Zajzon (2012). Clay mineralogy investigation at Kuhjoch itself is going on, those of the Strontium isotopes, Rare Earth Elements, $\mathrm{Ca} / \mathrm{Mg}$ are planned.

\section{Carbon isotopes and organic carbon content} (written byM. Ruhl and W.M. Kürschner) (Figs. 18, 19, 20b, 21, 24)

$\delta^{13} \mathrm{C}_{\text {org }}$ data (Fig. 24) have been documented from many sections of the Northern Calcareous Alps (Restental, Hochalplgraben, Kuhjoch/ Ochsentaljoch, Kendlbach, Schlossgraben, Steinplatte/Scheibelberg, Tiefengraben) and are discussed in detail by Ruhl et al. (2009). All these records show very regularly the distinct initial isotope excursion at the transition from the Kössen Formation to the Schattwald Beds. Two sections were studied at Kuhjoch: Kuhjoch West and Kuhjoch East. 


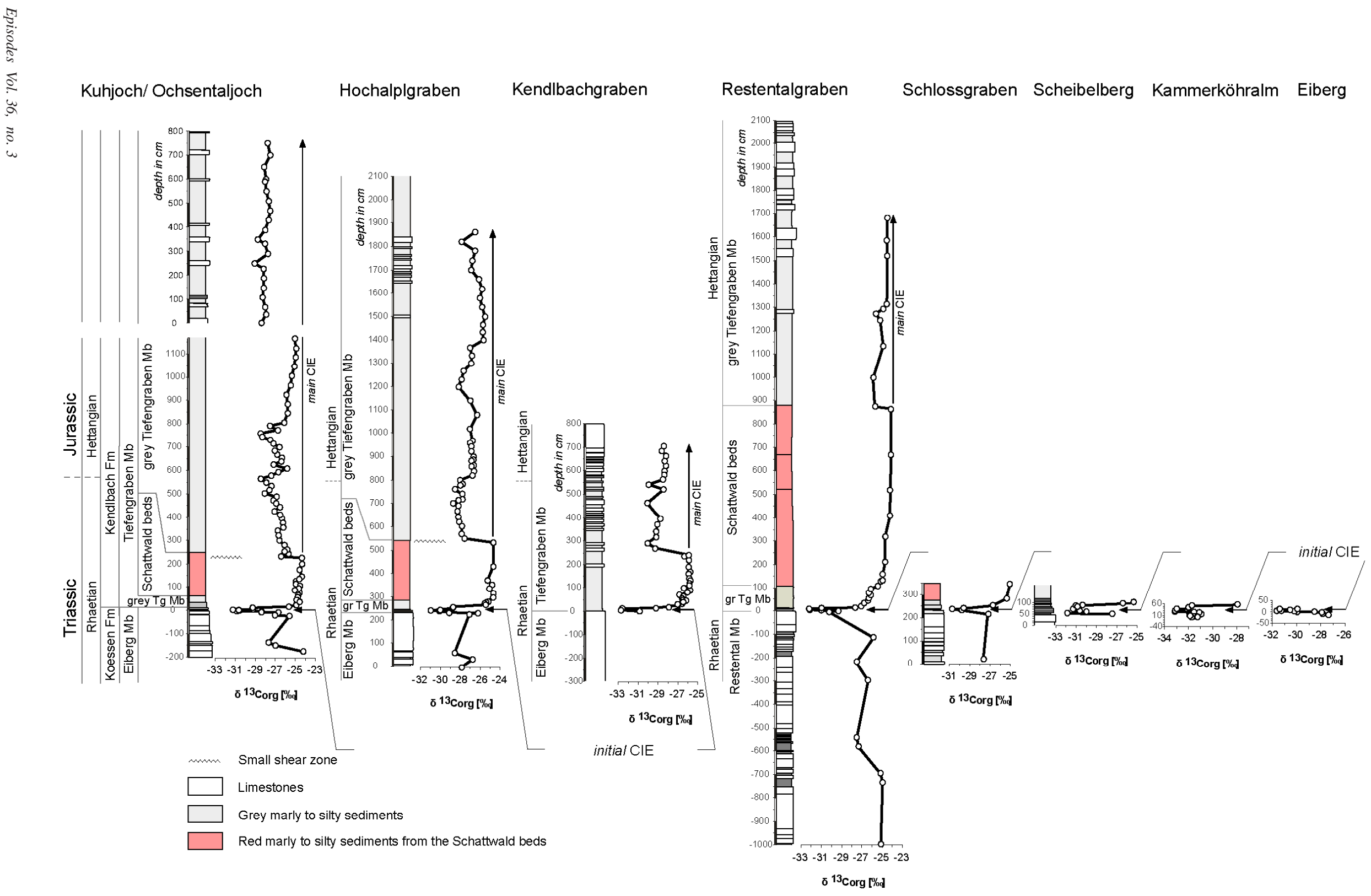

Figure 18. $8^{13} C_{\text {org }}$ curves for Eiberg-Tiefengraben members from Northern Calcareous Alps (Ruhl et al., 2009). 


\section{a) Kuhjoch section West (Fig. 19)}

In the Kuhjoch West section the transition from the Eiberg Member to the Tiefengraben Member was sampled at a $\mathrm{cm}$ scale. This interval is characterized by a distinct negative $\mathrm{C}$ isotope excursion with a maximum of about $-31 \%$ (Fig. 19). The onset of the $\delta^{13} \mathrm{C}_{\text {org }}$ peak coincides with a bituminous, black siltstone layer $(1 \mathrm{~cm})$ at the top of the thin-bedded marly limestone (T-Bed) of the uppermost Eiberg Member. The upper half of this negative carbon isotope excursion coincides with the top of the brownish marls with Pseudolimea, concretions of pyrite and worm-shaped traces. The $\mathrm{C}$ isotope curve turns to more positive values of about $-25 \%$ o within the lowermost $20 \mathrm{~cm}$ of the Schattwald Beds and remains rather stable within this interval. An abrupt $\sim 2 \%$ o negative shift (from $\sim-25$ to $\sim-27 \%$ o) occurs at the top of the Schattwald Beds at $\sim 2.5 \mathrm{~m}$ height in the section. This shift is related to a minor fault in the sedimentary record, marked by a $\sim 10$ to $20 \mathrm{~cm}$ thick and tectonically deformed clay horizon (Fig 19). The break in the sedimentary succession is also confirmed by a hiatus in the palynological record (see palynostratigraphic paragraph below, Fig. 24). In the Tiefengraben section this zone is characterized by a gradual negative trend from $26 \%$ o to $-28 \%$ o (Kürschner et al., 2007). The minor sedimentary hiatus in the Kuhjoch West record is succeeded by gradually decreasing $\delta^{13} \mathrm{C}_{\text {org }}$ values, from $\sim-27$ to $\sim-28.5 \%$ o, similar to the observed negative

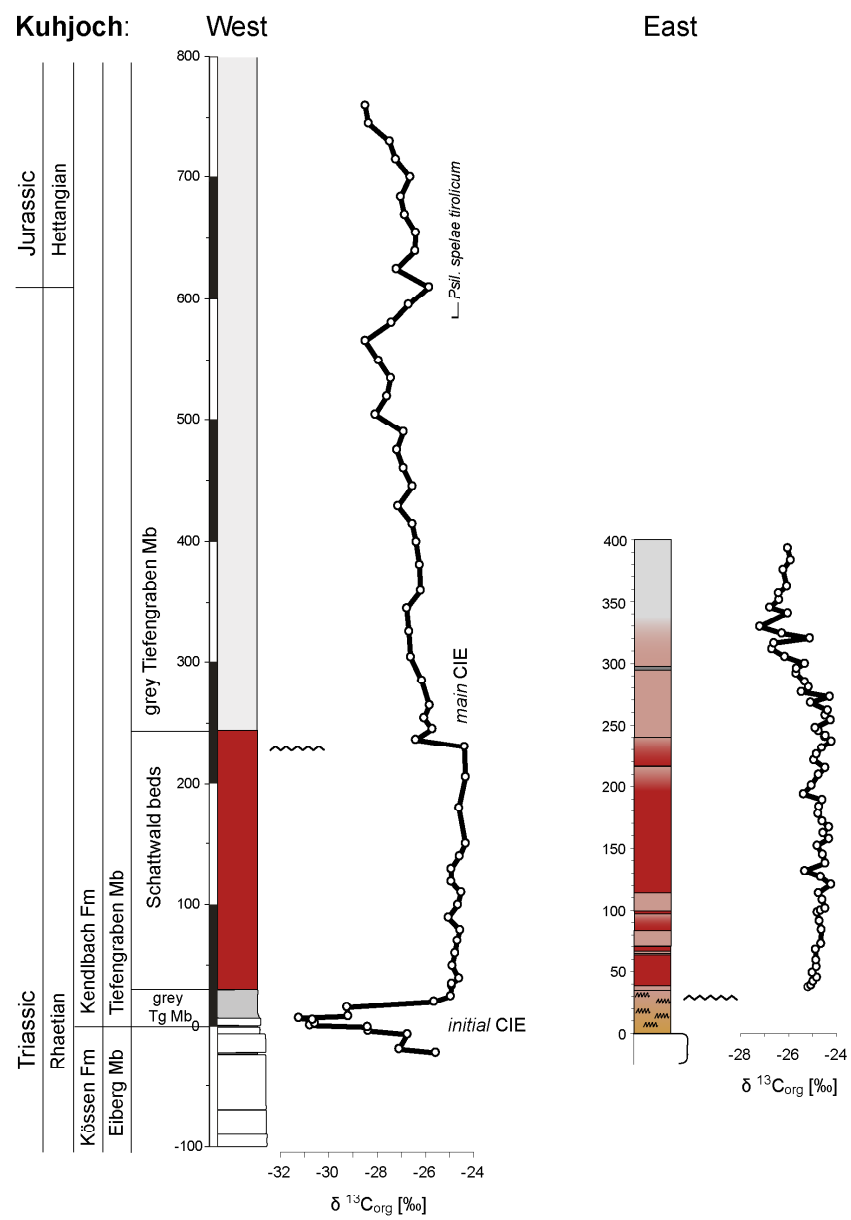

Figure 19. Detailed C-isotope curves from the Kuhjoch West and the Kuhjoch East sections, data for Kuhjoch West are from Ruhl et al. (2009), data for Kuhjoch East are from Schobben et al. (to be submitted). trend in the Tiefengraben $\delta^{13} \mathrm{C}_{\text {org }}$ record. This long-term gradual negative shift is interrupted by a significant positive shift (to -26\%o) at the level of the first ammonite horizon. This minor positive excursion is followed by less negative values and subsequently more depleted values at the top of the studied record.

\section{b) Kuhjoch section East (Fig. 19)}

To get the completeness of the Schattwald sedimentary record at Kuhjoch, a combined palynological and bulk C-isotope study has been carried out at Kuhjoch West as well at Kuhjoch East.

C-isotope values (Fig. 19) of the lower part of the Schattwald Beds, between the base of the sampled section and about $260 \mathrm{~cm}$ height, remain rather stable at around $-25 \%$. Between $260 \mathrm{~cm}$ and $330 \mathrm{~cm}$ C-isotope values turn gradually to more negative values with a minimum of $-27 \%$ at $330 \mathrm{~cm}$ and increase gradually again to less negative values of $-26 \%$ o towards the top of the section studied (at $400 \mathrm{~cm}$ ).

C-isotope analysis of the Schattwald Beds of the Kuhjoch section at the east side reveals no abrupt shifts (jumps) but a steady decline to more negative values. These values correspond to the jump in Cisotope values at $230 \mathrm{~cm}$ at the west side of the Kuhjoch section and support the presence of a small hiatus at this level, caused by a minor fault (Ruhl et al., 2009; Bonis et al., 2009), while the sedimentary succession at the east side is complete in this interval.

2. Total Organic Carbon (TOC) (written by M. Ruhl and W.M. Kürschner) (Fig. 20b)

The TOC curve shows a sharp maximum of about $10 \%$ at the black, bituminous layer, which coincides with the initial $\delta^{13} \mathrm{C}_{\text {org }}$ minimum, while the rest of the section shows only minor variations between 0 and $1 \%$. A similar pattern has been found throughout the Eiberg Basin.

\section{Kerogen analysis (written by M. Ruhl and W.M. Kürschner)}

Rock Eval pyrolysis has been used to identify the type and maturity of the sedimentary organic matter (Ruhl et al, 2010a). The initial Carbon Isotope Excursion (CIE) is marked by only minor changes in kerogen, which is distinctly terrestrial in origin. Increased TOC concentrations of $9 \%$ at the first half of the initial CIE coincide with $\mathrm{HI}$ values of over $600 \mathrm{mg} \mathrm{HC/g}$ TOC. The high correlation (with $\mathrm{R}^{2}$ $=0.93$ ) between $\mathrm{HI}$ values and terrestrial Cheirolepidiaceae conifer pollen suggests a terrestrial origin for the hydrogen enriched organic compounds in the sediment. The lack of major changes in the origin of the sedimentary organic matter suggests that the changes in the $\delta^{13} \mathrm{C}_{\text {org }}$ composition are genuine and represent true disturbances of the global C-cycle. This finding is supported by the compound specific $\mathrm{C}$-isotope record measured in higher plant $n$-alkanes (Ruhl et al., 2011).

\section{Carbon isotope in carbonate (written by S. Richoz)} (Fig. 21)

Compared to $\delta^{13} \mathrm{C}_{\text {org }}$ studies, rare $\delta^{13} \mathrm{C}_{\text {carb }}$ data are reported for the T-J boundary interval in the NCA. Only the Kendlbach section in the Eastern Eiberg Basin has been investigated by Hallam and Goodfellow (1990), challenged by Morante and Hallam (1996) and 

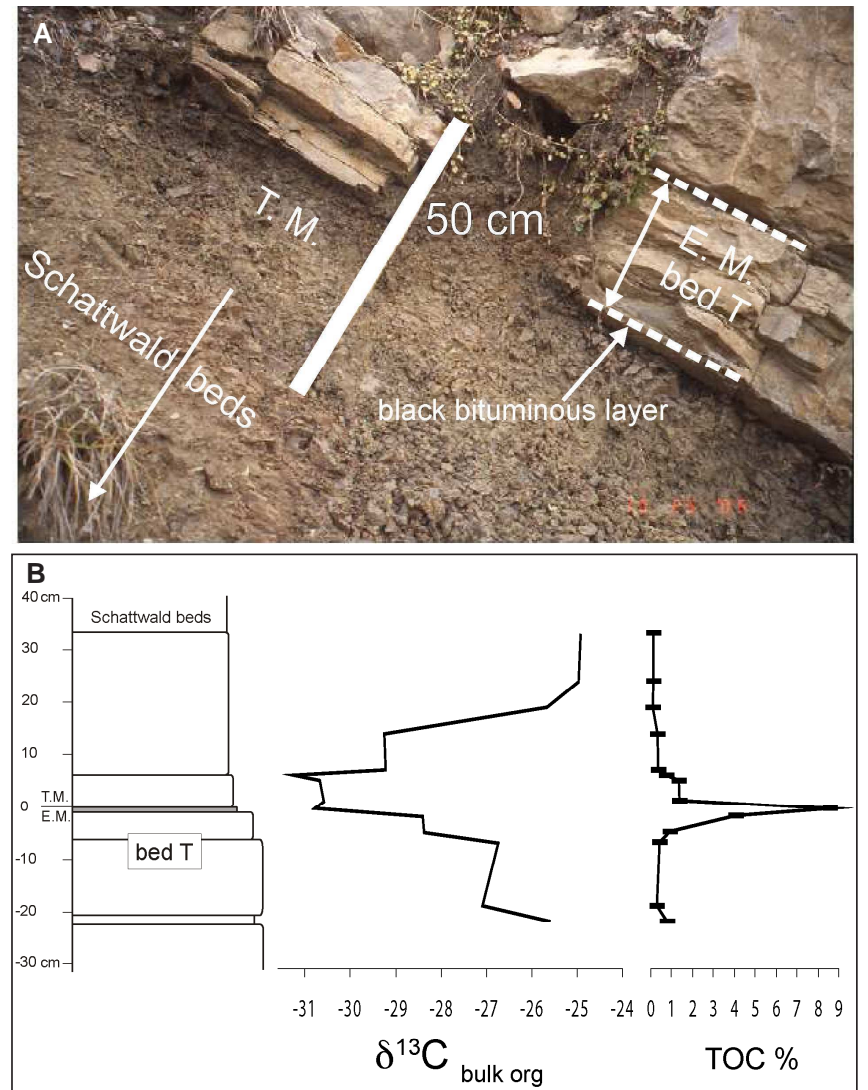

Figure 20. (A) Boundary between Eiberg (E.M.) and Tiefengraben members (T.M.) (Kuhjoch West section). Beds of photograph overturned. $(B) \delta^{13} C_{\text {org }}$ and TOC curves of the Eiberg - Tiefengraben members (Kuhjoch West section) (Ruhl et al., 2010a).

revisited by Korte and Kozur (2011). McRoberts et al. (1997) presented another curve from the Lorüns section in western Austria. Mette et al. (2012) published a $\delta^{13} \mathrm{C}_{\text {carb }}$ curve for the Late Rhaetian part of the Kössen Formation in Eiberg. A major problem is the very rare occurrence of carbonate beds in the almost pure terrigenous Tiefengraben Member, which do not allow a continuous carbonatic $\mathrm{C}$ isotopic curve through the boundary interval. Data presented here are also scattered, taken from different localities and carbonatic sources: we measured the uppermost Kössen limestones and the TBed at Scheibelberg, pelycypod fragments from a level $90 \mathrm{~cm}$ above the top of the Schattwalds Beds at Hinterissbach, ammonoids (Ps. spelae and Ps. cf. pacificum fragments), the foraminifer Reinholdella from the Ps. cf. pacificum level at Hochalplgraben and the limestones of the Breitenberg Mb. at Kuhjoch.

The Scheibelberg section is located at the southern margin of the Eiberg Basin and contains a particularly well-developed and expanded T-Bed. Its $\delta^{13} \mathrm{C}_{\text {org }}$ and TOC values have been published in Ruhl et al. (2009). The $\delta^{13} C_{\text {carb }}$ data in the Kössen Formation are around $1.8 \%$, corresponding to the mean values of the Eiberg Member (Mette et al., 2012). The values remain stable or even increase slightly through the lower T-Bed to start decreasing to $1.2 \%$ only in the upper T-Bed. A very short main negative excursion (to $0.2 \%$ ) is restricted to the topmost $10 \mathrm{~cm}$ of the T-Bed and thus records a distinct delay in comparison to the $\delta^{13} \mathrm{C}_{\text {org }}$ negative excursion.

Fossil remains from the Tiefengraben $\mathrm{Mb}$. provide various values with a maximum of $2.1 \%$ o for pelycypods, $2.0 \%$ for Ps. spelae, $4.3 \%$ for Ps. cf. pacificum and $1.1 \%$ for Reinholdella. All foraminifers measured show to some degree recrystallization of the test, which could explain the slightly more negative values. Ammonites from the Tiefengraben Member have been demonstrated to preserve aragonite. The two ammonites here measured display very different values. This difference could be explained by different metabolic effects on the isotopic composition of the shell (Seuss et al., 2012) or by a partial recrystallisation and transformation of the aragonite into calcite. Indeed by applying the ${ }^{13} \mathrm{C}$-fractionation between aragonite and calcite of $1.8 \pm 0.2 \%$ (Rubinson and Clayton, 1969) to the Ps. cf. pacificum leads to values around $2 \%$ being in agreement with the general trend. But using the correction factor for the Ps. spelae data would result in too negative values.

The limy sandstone at $14 \mathrm{~m}$, just above the $P$ s cf. pacificum level, of Kuhjoch provides a value of $1.4 \%$, whereas the first limestone bed of the Breitenberg Mb. has a value of $1.9 \%$. These values increase to $2.4 \%$ in the middle of this member to stabilize around $1.7 \%$ at the top and in the successive Adnet Formation. In conclusion, after the initial negative excursion, the values seem to remain constant between 1.5 and $2 \%$ as already observed by Hallam and Goodfellow (1990) without considering the values of the marls (Morante and Hallam, 1996), and by McRoberts et al. (1997).

Palaeomagnetism (written by M. Deenen, M. Szurlies, and W. Krijgsman)

Palaeomagnetic investigations have been started but all samples studied till now are remagnetized. Earlier investigations of Kössen Formation in the Steinplatte area (Fig. 1) have been shown to be remagnetized, which is in agreement with previous studies in the NCA (Pueyo et al., 2007). The organic rich sediments often contain also a lot of pyrite, which bias a primary signal.

\section{Biostratigraphy (Figs. 10, 11)}

Only a few fossil groups are suitable for high-resolution long distance correlations of Lower Jurassic strata, i.e. ammonites and radiolarians, of which the latter are almost missing in the studied sections. Ammonites are, therefore, the most important fossils for detailed biostratigraphic subdivision and correlation of the T-J boundary interval. Their high evolutionary potential provides the basis for a detailed biozonation (Fig. 22) and their wide geographic distribution in marine realms facilitates global correlations. Nannofossils and marine palynomorphs may also be of relatively high correlation potential. Of biostratigraphic or ecostratigraphic relevance are also bivalves, ostracods and foraminifers. Available terrestrial palynomorphs offer potential for marine - non-marine correlations.

1. Ammonites (Figs. 10, 22) (Hillebrandt and Kment, 2011; Hillebrandt and Krystyn, 2009)

The Kuhjoch, Ochsentaljoch, Rissbach and Hochalplgraben sections record 9 ammonite beds or levels of Late Rhaetian to Late Hettangian age:

- ammonite level (7) with ammonites of the Marmorea Zone (Late Hettangian)

- ammonite level (6) with ammonites of the Megastoma Zone (Middle Hettangian)

- ammonite level (5) with ammonites of the Calliphyllum Zone 
(condensed; including horizon with Psiloceras calliphyllumP. costosum and horizon with Psiloceras naumanni) +(upper part of Early Hettangian).

- ammonite level (5a) (Rissbach) with Psiloceras $\mathrm{cf}$. planorbis and $P$. n. sp. (upper part of Early Hettangian)

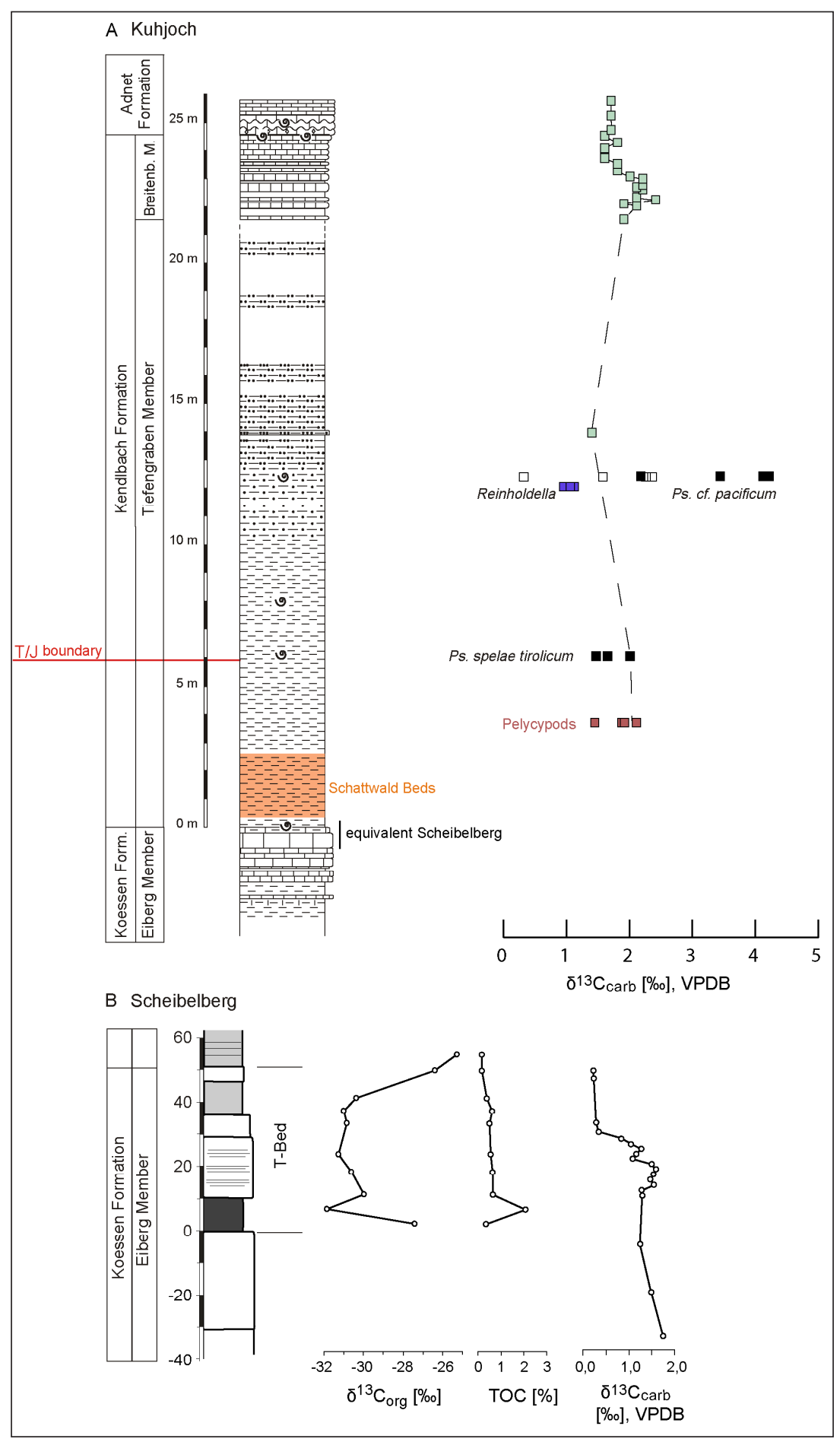

Figure 21. (A) $\delta^{13} C_{\text {carb }}$ values at Kuhjoch West section. The bivalve data (brown squares) are from the Hinterissbach section, some kilometers west of Kuhjoch, calibrated in the section with distance to the Schattwald Beds. Black squares are values for both ammonites, open squares are values for Ps $c f$. pacificum corrected for the ${ }^{13} C$-fractionation between aragonite and calcite. The violet squares refer to Reinholdella and turquoise squares are for selected micrite. (B) $\delta^{13} C_{c a r b}, \delta^{13} C_{o r g}$ and TOC data from Scheibelberg section; $\delta^{13} C_{\text {org }}$ and TOC are from Ruhl et al. (2009).
- ammonite level (4a) (Hochalplgraben) with Psiloceras sp. A (Fig. 17) (Hillebrandt and Krystyn, 2009, figs. 5, 11.6a,b) (lower part of Early Hettangian)

- ammonite level (4) Psiloceras cf. pacificum (lower part of Early Hettangian)

- ammonite level (3a at Kuhjoch and $3 \mathrm{~b}$ at Ochsentaljoch) with Psiloceras ex gr. P. tilmanni (lower part of Early Hettangian)

- ammonite level (2) with Psiloceras spelae tirolicum (lowest part of Early Hettangian (Figs.11.1-3)

- ammonite level (1) with Choristoceras marshi (Late Rhaetian) (Fig. 11.6)

2. Bivalves (Figs. 11.4-5) (written by C. McRoberts)

Cassianella and Chlamys valoniensis characterize the top Eiberg Member. Directly above is the FO of Agerchlamys together with Pseudolimea cf. hettangensis in the bituminous layer of the T-Bed, both taxa continuing up into the remainder of the Tiefengraben Member. Two species of Cardinia and a single one of Agerchlamys are found in different beds of the Tiefengraben Member, the latter form ranges up to the lower part of the Breitenberg Member. Of these bivalve taxa known from the GSSP interval, only Agerchlamys provides for limited global correlation to other T-J boundary sections where the FO consistently can be found immediately following the onset of extinction and negative $\mathrm{C}$ isotope anomaly (see McRoberts et al., 2007; McRoberts et al., 2012). The other bivalve taxa, while ecologically important, posses little biostratigraphic value.

\section{Ostracods (written by M. Urlichs) (Fig. 15)}

Many ostracod taxa found in the Tiefengraben Member are long ranging, for example from the Hettangian to the Late Pliensbachian or even to the Toarcian. Merely the Eucytherura and Nanacythere species have a stratigraphic range of only about one stage or somewhat more. The Tilmanni Zone is characterized by the co-occurrence of the Rhaetian Eucytherura sagitta, Eu. schulzi and the Hettangian Nanacythere elongata and $N$. paracostata. Unfortunately, these species are mostly very rare in the Karwendel sections. Ogmoconchella bristolensis, $O$. aspinata, and O. telata are against that frequent to abundant in the Tilmanni Zone of these sections and occur also in the Calliphyllum Zone. Both zones are characterized by the co-occurrence of these three Ogmoconchella species.

Ogmoconchella martini is the index fossil of the lower part of the "Middle" Rhaetian, of the martini Zone in England and of the upper "Middle" Rhaetian, the virgata Subzone in NW Germany. It has been furthermore recorded from the lower part of the Upper Rhaetian in England (Ainsworth and Boomer 2009, 


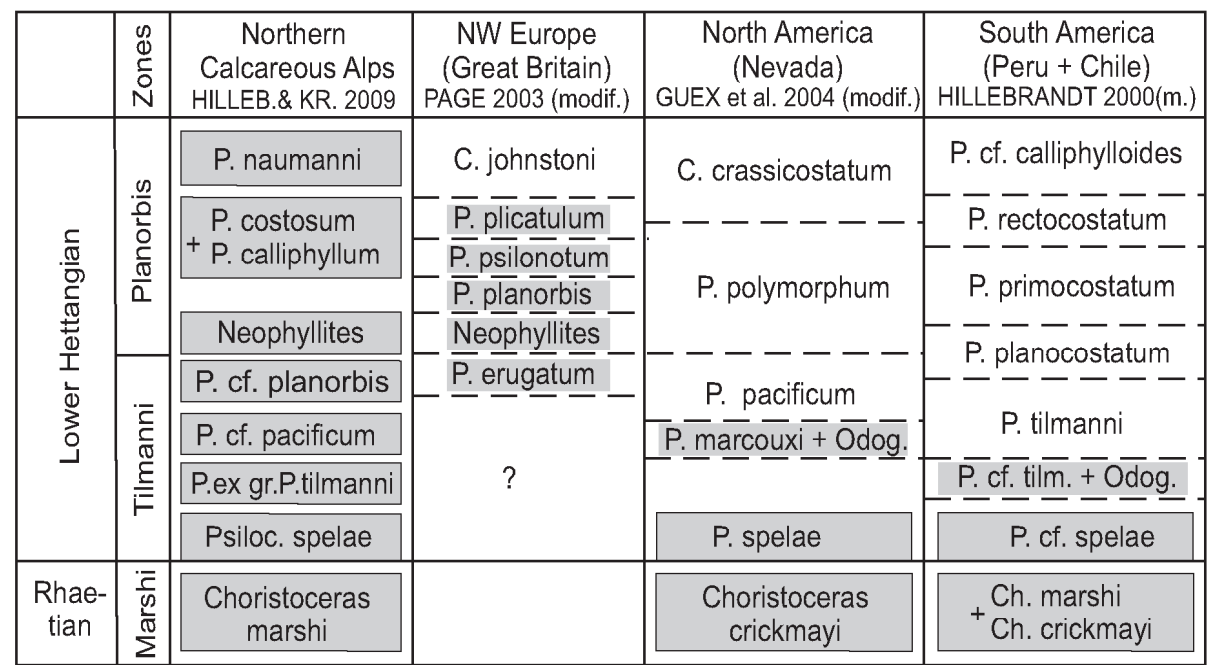

Figure 22. Correlation of Early Hettangian ammonite zones, subzones and horizons (grey), broken lines approximated correlation.

fig. 2) and has still a longer range in the Austroalpine Realm than in England and NW Germany, at least from the basal Stuerzenbaumi Zone to the top of the Marshi Zone (Middle to Late Rhaetian). The shorter stratigraphic ranges in the Europe outside of the Alps probably result from low salinity during the Late Rhaetian.

After the disappearance of Ogmoconchella martini at Kuhjoch, the first appearance of Ogmoconchella aspinata $(=O$. ellipsoidea $)$ at the base of the Tilmanni Zone may be an approximate biostratigraphic marker for the base of the Hettangian. However, the first appearance of $O$. aspinata is not coeval in different regions. In England, this species already occurs from the Lower Rhaetian to the lower part of the Upper Rhaetian (Ainsworth and Boomer 2009, fig. 2) and continues to the earliest Sinemurian (Boomer and Ainsworth 2009, fig. 2). These Rhaetian occurrences should be reconsidered. In continental Europe outside of the Alps, the earliest records of $O$. aspinata come from the Planorbis Zone of Ardèche, Paris Basin, Lower Saxony, and Denmark. In SW Germany, this species appears later, in the early Liasicus Zone (Middle Hettangian), because the condensed carbonatic lithology of the "Psilonotenbank" (Psilonotum Zone) is unsuitable for the extraction of ostracods. Based on ostracods alone, an exact correlation of the Austroalpine Late Rhaetian and Early Hettangian with NW and Central Europe is at present impossible.

\section{Foraminifers (Figs. 10, 12-14) (Hillebrandt, 2010, 2012)}

The nodosariid fauna of the T-Bed and of the bituminous layer is typical for the Rhaetian just as is the impoverished fauna with large Marginulinopsis of the lower part of Tiefengraben Member. The monotonic predominance of Hippocrepina in the Schattwald Beds allows no age assignment. The mostly small-sized nodosariids and polymorphinids of the grey marls of the Tiefengraben Member above the Schattwald Beds are poor in species. Characteristic genera like Ichthyolaria do not occur and specimens of the Lingula tenera group are very rare in the lower and middle part of the Tiefengraben Member.

The aragonitic Robertinina are of biostratigraphic importance (Figs. 11, 14) (Hillebrandt, 2010). Oberhauserella was described from the Late Triassic and is still present with various species in the grey marls below the Psiloceras spelae horizon. Praegubkinella turgescens appears 50 to $60 \mathrm{~cm}$ below and disappears about $1.2 \mathrm{~m}$ above the spelae horizon, which is about $40 \mathrm{~cm}$ thick. Transitional forms to
Reinholdella $\mathrm{n} . \mathrm{sp}$. are first found above this level. The horizon with Psiloceras cf. pacificum yields another new species of Praegubkinella. In the Hochalplgraben section a third species of Praegubkinella occurs between the horizons with Psiloceras spelae tirolicum and Psiloceras cf. pacificum. Reinholdella $\mathrm{n}$. sp. continues to the upper part of the Tiefengraben Member (Ochsentaljoch section). Oberhauserella and Praegubkinella are not only found in the Eiberg Basin but also in the Allgäu and Hallstatt basins. A section in the latter (near Bad Goisern) revealed the same Oberhauserellidae evolution and the characteristic size increase from Oberhauserella to Praegubkinella. These aragonitic foraminifers are thus very important biostratigraphical proxies for the T-J boundary since their rapid evolutionary development takes place in different Alpine regions close to the spelae horizon.

\section{Calcareous nannofossils (written by P. Bown) (Figs.} $16,17)$

Contrary to the Kössen Formation, coccoliths s.s. are very small and very rare in the Tiefengraben Member where neither typical "Liassic" nannofossils (e. g. Schizosphaerella - the dominant Liassic nannolith), nor any true coccoliths have yet been found. More samples have to be studied as changes in the "calcisphere" assemblages could be of biostratigraphic importance for the turnover from the Triassic to the Jurassic, which is not well constrained.

6. Palynomorphs (Figs. 10, 23-26) (written by N.R. Bonis, M.A.N. Schobben, and W.M. Kürschner)

Several studies in the Northern calcareous Alps (NCA) have described the microfloral record across the Triassic-Jurassic (T-J) transition (Morbey, 1975; Karle, 1984; Schuurman, 1979). The discovery of a negative C-isotope excursion (CIE) at the base of the Tiefengraben Member (Kürschner et al, 2007), that correlates with the initial and main negative CIE in many other T-J key sections (e.g. Palfy et al., 2001; Hesselbo et al., 2002; Guex et al., 2004), has renewed the interest in high resolution palynostratigraphic studies in the NCA, which allows calibration of the pollen and spore record with an independent chemo- and marine biostratigraphic framework (Bonis et al., 2009, 2010a; Bonis and Kürschner, 2012). In the western Eiberg Basin, Bonis et al. (2009) presented a detailed high-resolution microfloral record for the Hochalplgraben section together with preliminary data from the Kuhjoch W section. The following paragraph summarizes a new high-resolution palynostratigraphic study from the Kuhjoch GSSP in both outcrops, on the western and eastern flank and represents a revision of earlier work (Bonis et al., 2009). A more detailed account of the palynology of the Kuhjoch sections will be published elsewhere (Schobben et al., to be submitted)

a) Kuhjoch West section (Figs. 10, 23, 25)

In total 44 sub-samples were taken from the same sediment 


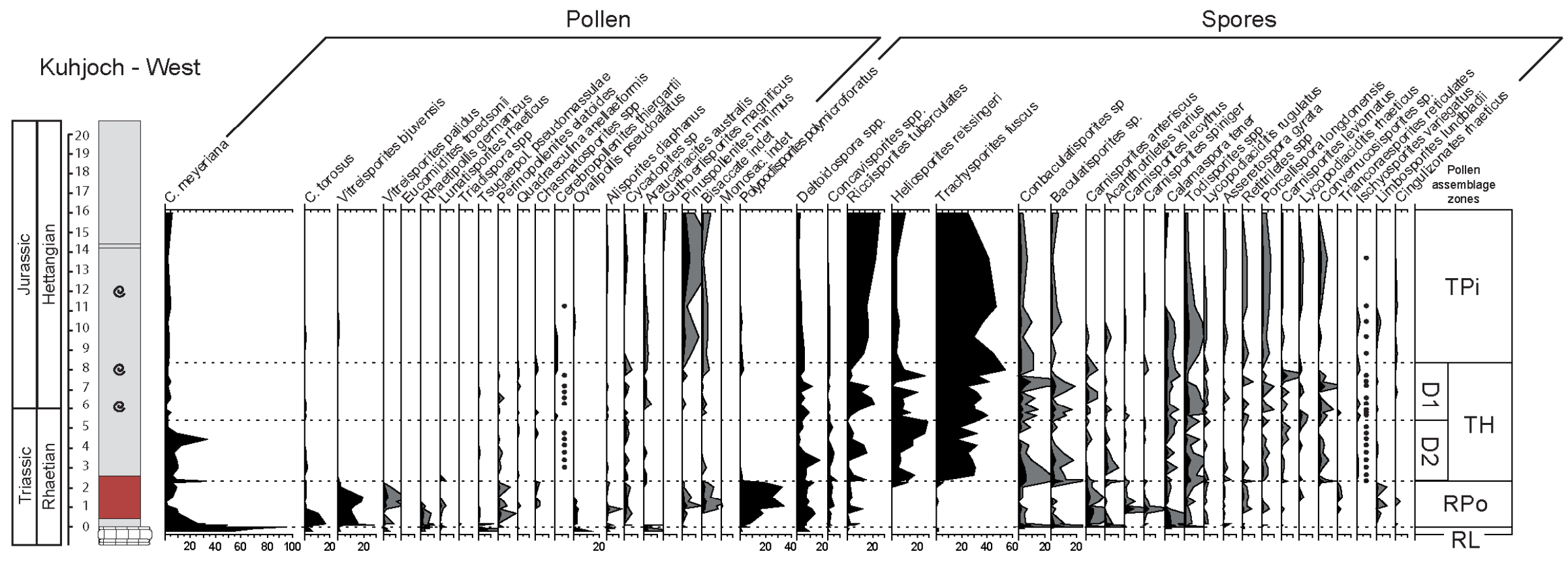

Figure 23. Relative abundances [\%] of pollen and spores through the T-J boundary interval in the Kuhjoch West section and their correlation with pollen assemblage zones after Kürschner et al. (2007), whereby $R L=$ Rhaetipollis - Limbosporites zone, $R P o=$ Rhaetipollis-Porcellispora zone, $T H=$ Trachysporites-Heliosporites zone (with D1and D2 as local subzones that correlate with local pollen assemblages $\mathrm{H3}$ and $\mathrm{H} 4 \mathrm{a}$ in Hochalplgraben (Bonis et al., 2009)), TPi = Trachysporites-Pinuspollenites zone. 


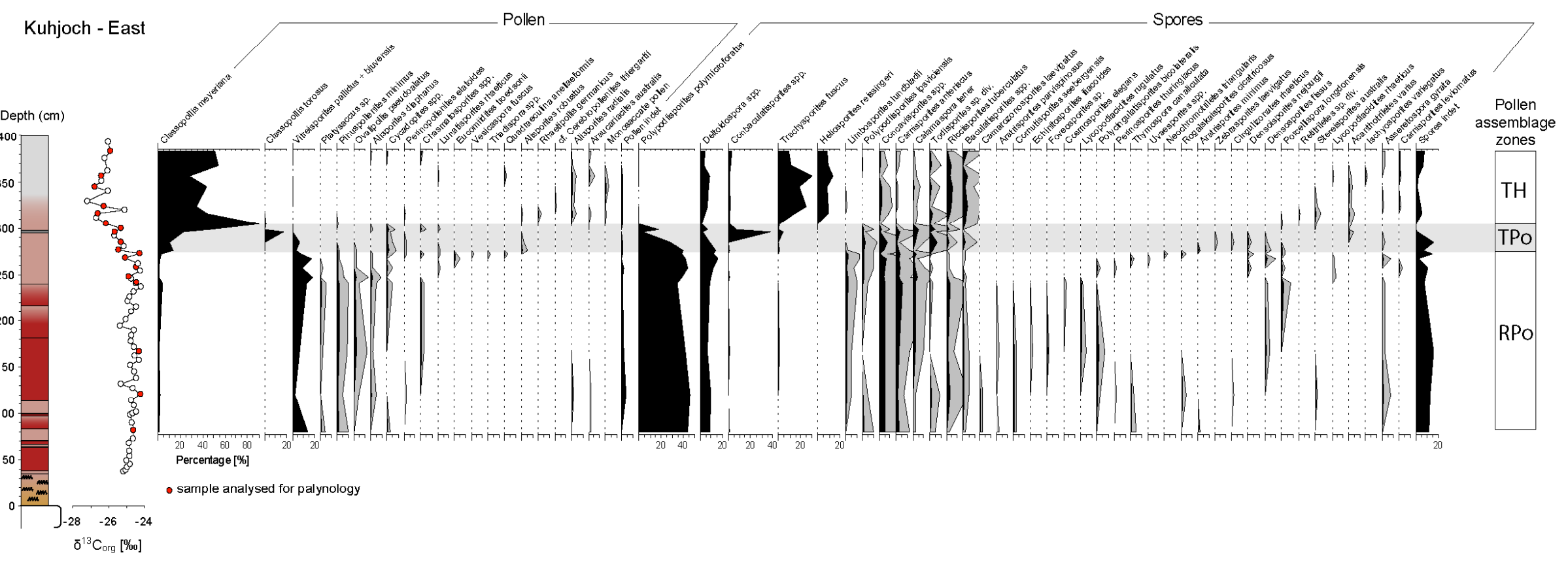

Figure 24. Relative abundances [\%] of pollen and spores through the T-J boundary interval in the Kuhjoch East section and their correlation with pollen assemblage zones after Kürschner et al. (2007), whereby RPo = Rhaetipollis-Porcellispora zone, TPo = Trachysporites-Porcellispora $z o n e$, TH = Trachysporites-Heliosporites $z o n e$. 


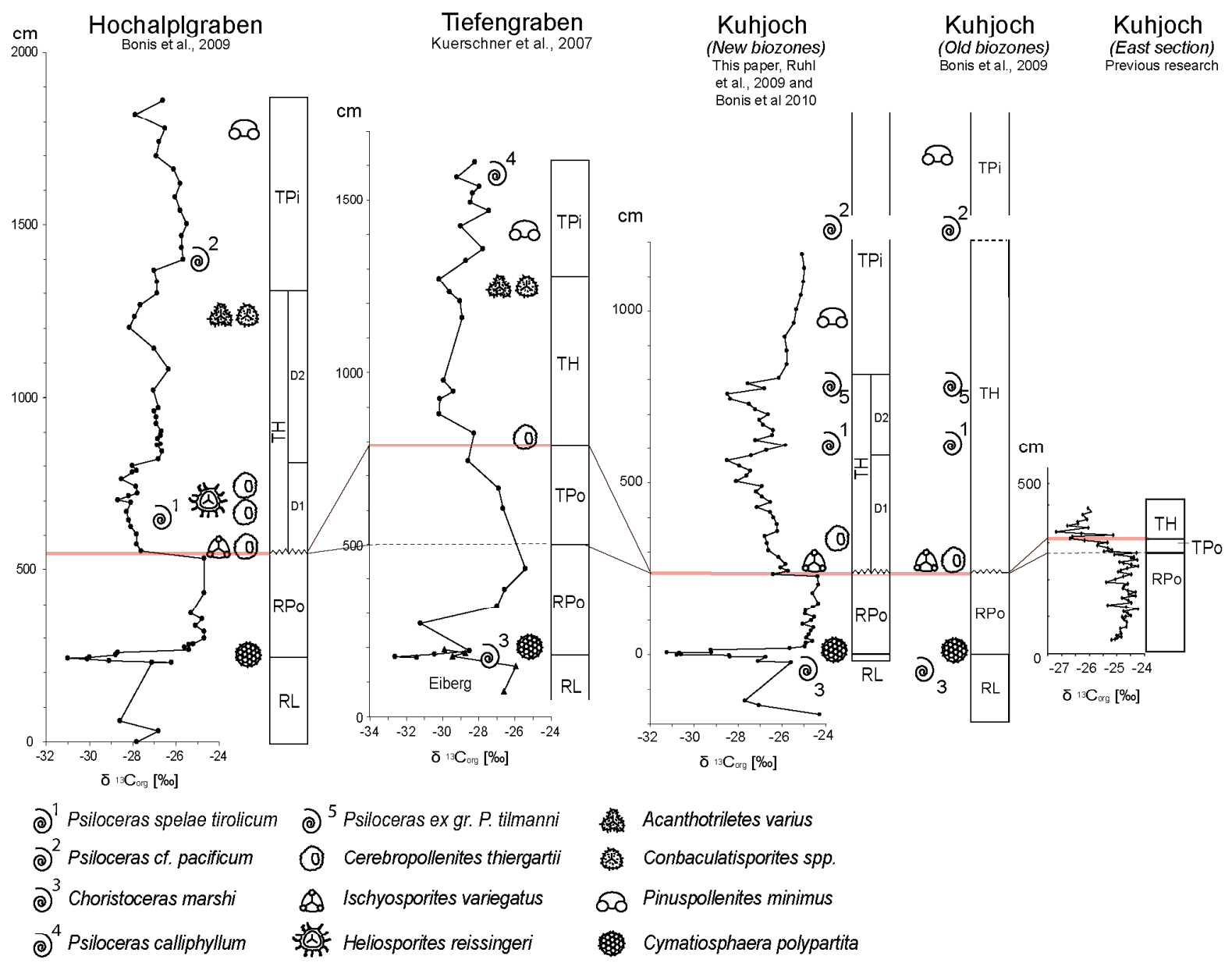

Figure 25. Correlation of Kuhjoch West, Kuhjoch East, Hochalplgraben and Tiefengraben sections based on C-isotope stratigraphy, palynomorph assemblage zones and bio-events, such as FO of ammonites and pollen/spore taxa, position of Cymatiosphaera acme, marked increase in abundance of pollen and spores (e.g. Heliosporites, Pinuspollenites). The pollen assemblage zones are based on Kürschner et al. (2007), Bonis et al. (2009) and Schobben et al. (to be submitted). Dotted lines are correlations based on C-isotope stratigraphy from Ruhl et al. (2009). $R L=$ Rhaetipollis-Limbosporites zone, $R P o=$ Rhaetipollis-Porcellispora zone, $T P o=$ Trachysporites-Porcellispora zone, $T H$ = Trachysporites-Heliosporites zone (with D1and D2 as local subzones previously local pollen assemblages H3 and H4a in Hochalplgraben (Bonis et al., 2009)), TPi = Trachysporites-Pinuspollenites zone; Red line: base of TH zone.

samples previously studied for the C-isotope composition (Ruhl et al., 2009) and organic geochemistry (Ruhl et al., 2010, 2011). This allows a direct integration of the palynostratigraphy with the $\mathrm{C}$-isotope stratigraphy. The microfloral record across the boundary is characterized by marked changes in the terrestrial palynomorph assemblages that correlate with those of the Tiefengraben section in the eastern part of the Eiberg Basin (Kürschner et al., 2007). Based on cluster analysis 4 pollen assemblage zones can be recognized in the Kuhjoch W section (Fig. 23):

(1) The lowermost interval (base of section = base of Kendlbach Formation to $28 \mathrm{~cm}$ height) is dominated by Classopollis meyeriana and Classopollis torosus accompanied by Ovalipollis pseudoalatus. Rhaetipollis germanicus, Limbosporites lundbladii, and Cingulizonates rhaeticus are present. This assemblage corresponds to the Rhaetipollis - Limbosporites zone (RL zone).

(2) The next interval $(28 \mathrm{~cm}$ to $255 \mathrm{~cm}$ height) is mainly characterized by an abrupt decline in C. meyeriana, while C. torosus and Vitreisporites bjuvensis increase up to $20 \%$. Furthermore the diversity and abundance within spores increase, typically Polypodiisporites microforatus (>20\%), Deltoidospora spp.,
Concavisporites spp. and Ricciisporites tuberculatus. The top of this interval shows again an acme of C. meyeriana (>30\%), while Heliosporites and Trachysporites enter the record. This assemblage correlates with the Rhaetipollis - Porcellispora zone (RPo zone).

(3) In the following interval $(255 \mathrm{~cm}$ to $810 \mathrm{~cm}$ height), which can be further subdivided in two subzones, $C$. meyeriana remains an important constituent up to $20 \%$ but other pollen, such as Vitreisporites bjuvensis, Ovalipollis pseudoalatus, and Rhaetipollis germanicus that were common in previous zones are absent. Furthermore, Cerebropollenites thiergartii, and Ischyosporites variegatus have their FOD at the base of this zone. Moreover Polypodiisporites microforatus disappears, while Heliosporites and Trachysporites become dominant $(30 \%)$. In the upper part of this interval Trachysporites dominates the sporomorph assemblages with abundances of more than $40 \%$ accompanied by Riccisporites $(20 \%)$. C. meyeriana abundance decreases to values around $10 \%$ and remains stable. This assemblage correlates with the Trachysporites Heliosporites zone (TH zone).

(4) In the following interval $(810 \mathrm{~cm}$ to $1600 \mathrm{~cm}$ height $)$ the most notable feature is a marked increase in abundance of Pinuspollenites 


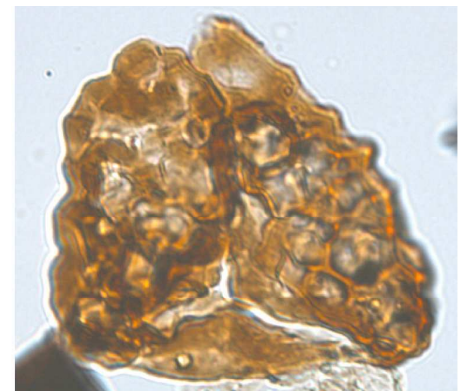

1

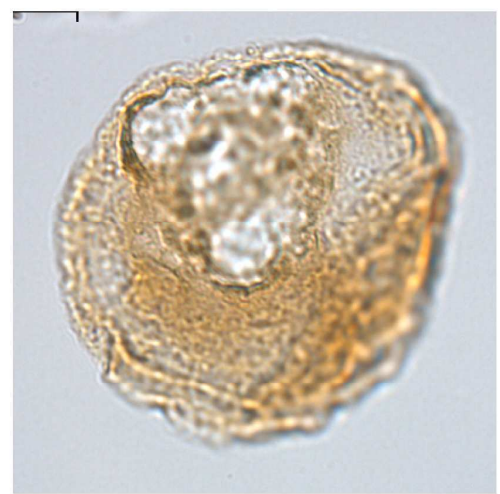

4

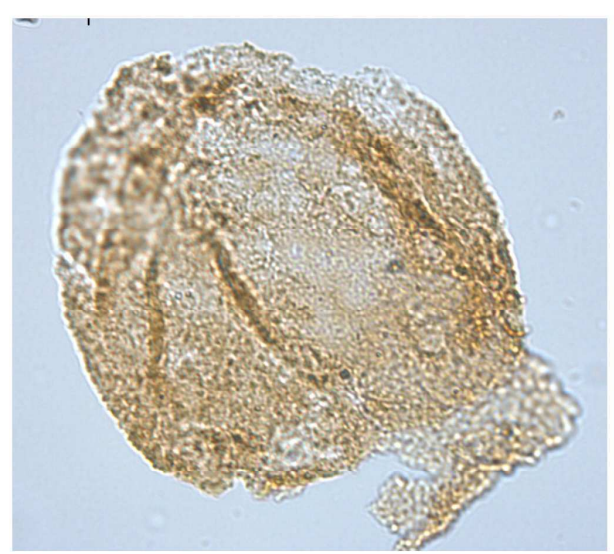

6

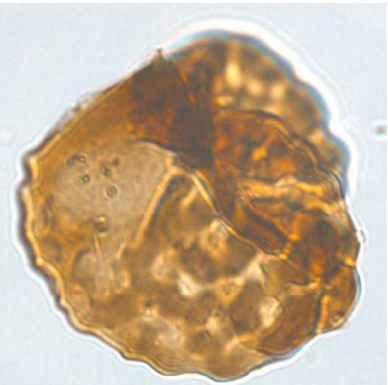

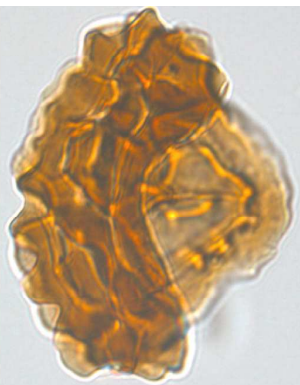

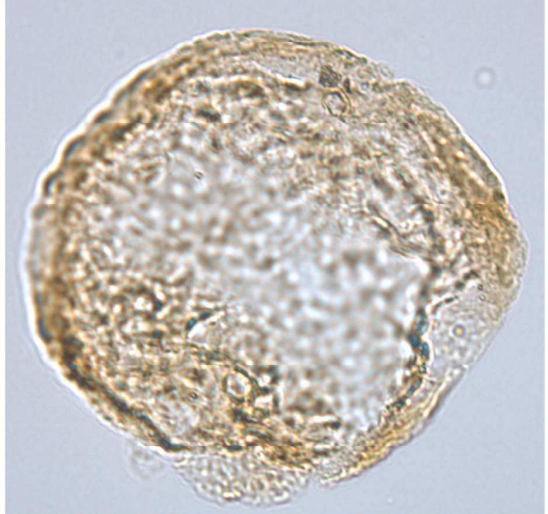

5

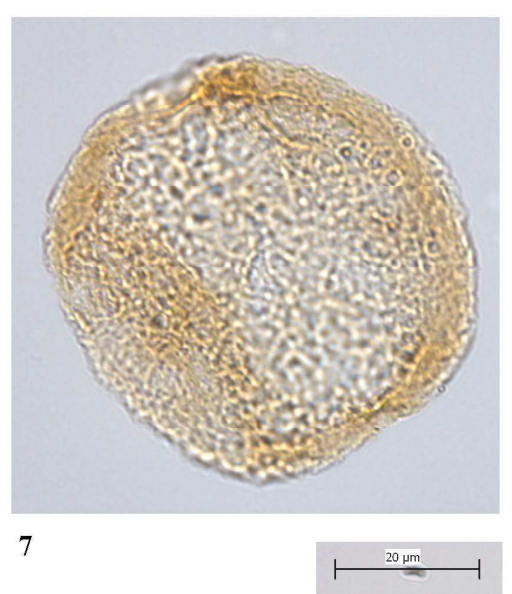

Figure 26. Light microscope illustrations of spores and pollen that mark the TriassicJurassic boundary interval (1-3) Ischyosporites variegatus, (4-7) Cerebropollenites thiergartii .

minimus and Ricciisporites tuberculatus, while Trachysporites remains dominant. This assemblage correlates with the Trachysporites - Pinuspollenites zone (TPi zone).

\section{b) Kuhjoch East section (Figs. 24, 25)}

The Kuhjoch-E palynomorph record consists of 17 samples, which were collected in 2008 from a trench (about 50-100 cm deep) 20 meters to the east side of the original Kuhjoch-W section (Fig. 8). The sampled $\sim 400 \mathrm{~cm}$ interval in the Kuhjoch-E section covered the Schattwald Beds and the transition to the succeeding gray Tiefengraben $\mathrm{Mb}$. The lowermost $30-40 \mathrm{~cm}$ from the Tiefengraben $\mathrm{Mb} /$ Schattwald Beds in the Kuhjoch-E section, directly succeeding the carbonates from the Kössen Fm., was not sampled because of

tectonic disturbance. This tectonic disturbance most likely reflects the same tectonic fault as at the top of the Schattwald Beds at Kuhjoch$\mathrm{W}$, which cuts through the stratigraphy.

Significant changes in the terrestrial palynomorph assemblages occur within the Schattwald Beds. 3 different pollen assemblage zones have been distinguished by cluster analysis:

(1) The lowermost interval (base of section to $275 \mathrm{~cm}$ height) is characterized by diverse spore assemblages with high abundances of Polypodiisporites polymicroforatus $( \pm 40 \%)$ accompanied by Deltoidospora spp., Concavisporites spp., Carnisporites spp., Limbosporites lundbladii and others. The proportion of pollen is rather low consisting mainly of Vitreisporites pallidus and $V$. bjuvensis, accompanied by Classopollis meyeriana, Ovalipollis pseudoalatus, and Platysaccus sp. This assemblage correlates with the Rhaetipollis - Porcellispora zone (RPo zone), which is the second pollen assemblage zone in the Kuhjoch-W section.

(2) The following assemblage $(275 \mathrm{~cm}$ to $310 \mathrm{~cm}$ height) is transitional between assemblages the RPo zone and the TH zone. It is characterized by a marked and steadily increasing abundance of pollen, particularly of $C$. meyeriana, while $V$. pallidus and $V$. bjuvensis decline. Also spores, which were dominant in the previous assemblage, such as P. polymicroforatus and Deltoidospora spp. decline significantly, while Conbaculatisporites spp. has a brief acme within this interval. Trachysporites fuscus shows a slight increase. Some palynomorphs that are characteristic guide forms of the Rhaetian, such as $O$. pseudoalatus, Lunatisporites rhaeticus, and L. lundbladii have their last occurrence. This assemblage correlates with the Trachysporites - Porcellispora zone (TPo zone) of the Tiefengraben section (Kürschner et al., 2007), which is absent in the KuhjochW section (see further discussion below)

(3) The following interval $(310 \mathrm{~cm}$ to $390 \mathrm{~cm})$ is characterized by an acme of $C$. meyeriana $( \pm 80 \%)$, which is followed by a decline down to $\pm 40-60 \%$ for the remaining part of this interval. Spores, particularly $T$. fuscus and Heliosporites reissingeri show a marked increase. At the base of this assemblage, Cerebropollenites thiergartii has its first occurrence. This assemblage correlates with the Trachysporites - Heliosporites zone (TH zone).

The RPo zone of the Tiefenbach could be recognized in the Kuhjoch W and E sections as well as in the Hochalplgraben section (Bonis et al., 2009) because of high diversity of spores with the dominance of $P$. polymicroforatus, the moderate abundance of $V$. pallidus / $V$. bjuvensis and the low abundance of $C$. meyeriana.

The second pollen assemblage zone at Kuhjoch E shows distinctly gradual changes in the abundance of the pollen and spores, such as 
an increase in $C$. meyeriana, a decrease in V. pallidus, $V$. bjuvensis, and $P$. polymicroforatus and a brief acme of Conbaculatisporites. This assemblage correlates with the TPo assemblage zone in the Tiefengraben section (Kürschner et al., 2007) because of the decrease in P. polymicroforatus and Deltoidospora, while Concavisporites and Trachysporites increases. Note that the increase in Trachysporites precedes the increase in Heliosporites. The latter characterizes the base of the following TH zone in Tiefengraben (Kürschner et al., 2007).

By contrast, in the Kuhjoch W outcrop and the Hochalplgraben the transition from the assemblages from the RPo to the TH zone is characterized by an abrupt increase (acme) in C. meyeriana and the disappearance of $V$. pallidus, $V$. bjuvensis, and P. polymicroforatus, while the acme of Conbaculatisporites is lacking.

This transitional pollen zone is not present at Hochalplgraben and Kuhjoch $\mathrm{W}$ because of a minor hiatus caused by a fault. In the Kuhjoch E outcrop this interval is undisturbed and characterized by a gradual decrease in $\mathrm{C}$-isotope values from $-25 \%$ o to $-27 \%$, which is similar in magnitude as the abrupt shift at the top of the Schattwald Beds in Hochalplgraben and Kuhjoch West (Fig. 2). Therefore $\mathrm{C}$ - isotopes and palynological results independently indicate the presence of a small hiatus at the top of the Schattwald Beds in these two sections and a continuous sedimentary record at Kuhjoch East. The following TH zone can be recognized in all 3 sections (Kuhjoch East, Kuhjoch West and Hochalplgraben) because the dominance of C. meyeriana (and the acme at the base of this interval) accompanied by high abundances of spores such as Heliosporites and Trachysporites.

The fine resolution palynological analysis of the 2 Kuhjoch sections, the nearby Hochalpgraben section and the Tiefengraben section in the eastern part of the Eiberg basin and the Restental section (Mazumder, 2013) show that the pollen assemblage zonation supposed by Kürschner (2007) can be applied for regional correlation throughtout the NCA. However, further studies have to show if similar fine resolution correlations can be established within the Tethys realm. As the succession of the pollen assemblage zones reflects vegetation changes to regional climate changes we expect more complex vegetation patterns on a larger lateral scale (see also Bonis \& Kürschner, 2012). This will limit the use for direct one to one correlations on extra-regional long-distances.

\section{c) Correlation within the Eiberg Basin (Fig. 25)}

The new high-resolution study of the Kuhjoch sections shows that palynomorph assemblages from this section correlate one to one with those reported from the Hochalplgraben section and the Tiefengraben section. Several bio-events can be recognized in all three sections across the T-J boundary interval (Fig. 24). These include the LO of typical Triassic palynomorphs such as Lunatisporites rhaeticus, Ovalipollis pseudoalatus, and Rhaetipollis germanicus, Triancoraesporites spp. in the Schattwald Beds of the Kendlbach Formation clearly above (ca. $2 \mathrm{~m}$ ) the LO of Choristoceras marshi. Bio-events above the Schattwald Beds are the FO of Cerebropollenites thiergartii and Ischyosporites variegatus, a marked increase in Heliosporites reissingeri and Trachysporites fuscus (ca. $3 \mathrm{~m}$ below the FO of P. spelae) and the occurrence of Pinuspollenites minimus higher up in the section. The TPo zone, however, is lacking in the Kuhjoch West and Hochalplgraben, due to a minor tectonic fault coinciding with an abrupt shift in the C-isotope records. Our new palynological and C-isotope data show that the TPo zone is clearly present in the Kuhjoch East section, showing the undisturbed nature of the upper part of the Schattwald Beds.

\section{Radiometric Geochronology}

No radiometric data of the T-J boundary are known from the Northern Calcareous Alps or elsewhere in Europe contrary to South and North America from where many radiometric age determinations were published in the last two decades. The CAMP volcanic rocks provided many data and also volcanic ashes intercalated to marine sediments. Palfy et al. (2000) dated in Canada (Queen Charlotte Islands) a tuff layer in marine sediments with an age of 199.6 \pm 0.3 Ma. This tuff is found immediately below the change of radiolarian faunas near to the T-J boundary. Schoene et al. (2010) and Guex et al. (2012) dated in Peru tuff layers of the latest Rhaetian with an age of $201.40 \pm 0.18$ and 201.45 \pm 0.14 Ma. Earliest Hettangian (Psiloceras spelae horizon) (Guex et al., 2012) samples between two tuff layers were dated with an age of $201.35 \pm 0.10$ and $201.26 \pm 0.13 \mathrm{Ma}$. The distances between the samples differ between the two publications. Schoene et al. (2010) determined also an earliest Hettangian tuff bed ca. $1.5 \mathrm{~m}$ above the Psiloceras spelae horizon of the New York Canyon section (Nevada, USA) with an age of $201.33 \pm 0.13 \mathrm{Ma}$. The same author dated the lowest part of the CAMP North Mountain basalt (Nova Scotia, Canada) with an age of 201.38 \pm 0.02 Ma. Marzoli et al. (2011, fig. 2) presented a correlation of different North American CAMP basins and the High Atlas (Morocco) based on radiometric ages of superimposed volcanites. The lowest basalts were dated with

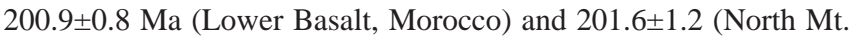
Basalt of the Fundy Basin, Canada).The averaged age of the T-J boundary can be estimated at around 201.3 Ma.The latest radiometric data of CAMP volcanic rocks were published by Blackburn et al. (2013). The Palisade sill of the Orange Mountain Basalt (oldest volcanite of the Newark Basin, USA) was dated with an age of 201.520 $\pm 0.034 \mathrm{Ma}$, the North Mountain Basalt (oldest volcanite of the Fundy Basin, Canada) with an age of 201.566 $\pm 0.031 \mathrm{Ma}$ and the Amelal sill (Intermediate Unit) of the Argana Basin (Morocco) with an age of $201.564 \pm 0.054 \mathrm{Ma}$.

\section{Correlations}

\section{Regional}

Ammonite level (2) - the boundary level - is presently known from six sections, level (4) from four sections, and levels ( $3 a, b)$ from two sections in the western Karwendel syncline over a lateral distance of nearly 10 kilometers. Ammonite levels (5) to (7) are known from many sections of the western Karwendel Syncline (Hillebrandt and Kment, 2011). These levels are also found in different sections of its northern flank (Kment, 2000). The bivalve fauna and the negative isotope excursion of the Kuhjoch section in the boundary bed(s) from the Eiberg to the Tiefengraben Member can be observed in many other sections and provide a first order correlation level within the Eiberg Basin; the same applies for ammonite levels (1) and (5).

Ammonite levels (1) to (3) and (5) to (7) are present also in the Zlambach Basin. In this region small specimens of Psiloceras spelae tirolicum (2) were found together with a small Phylloceras similar to the specimen found in the spelae horizon of Kuhjoch. A second ammonite bed, some meters higher up, yielded large sized 
Schistophylloceras and small sized Psiloceras cf. tilmanni (3). Vertical changes within the microfaunas allow further fine-tuned correlations within the Tiefengraben Member throughout the Eiberg Basin and also the Allgäu and Zlambach basins.

Many sections of the western Eiberg Basin show a lithological and faunal record of the T-J boundary interval comparable to that of the GSSP. Some of the more important sections are the Schlossgraben $\left(47^{\circ} 28^{\prime} 30^{\prime \prime} / 11^{\circ} 29^{\prime} 0 "\right)$, with a flat-lying and exceptionally good exposure of the top Kössen and basal Kendlbach Formation, which has been also - but without success - studied for magnetostratigraphy. The Hochalplgraben $\left(47^{\circ} 28^{\prime} 20^{\prime \prime} / 11^{\circ} 24^{\prime} 42^{\prime \prime}\right)$ (Fig. 2) shows the presently best-preserved psiloceratids of the ammonite levels (2) and (4) (Hillebrandt and Krystyn, 2009; Hillebrandt and Kment, 2011, fig. 4) and the most promising nannofossil record. The Hochalplgraben section is the type locality of Psiloceras spelae tirolicum. Level (2) also was found in the steep trench (Rohnberggraben) between Rohnberg (east of Hochalplgraben) and Hinterriß. The Rissbach (47 $\left.28^{\prime} 26^{\prime \prime} / 11^{\circ} 28^{\prime} 6^{\prime \prime}\right)$ section (Fig. 2) opposite to Hinterriß contains the ammonite levels (2), (4), (5a, with a limestone bed at the boundary of the Tiefengraben und Breitenberg Member containing $P$. cf. planorbis and a new species of Psiloceras, Fig. 22) and (5).

Within the northern flank of the Karwendel Syncline, three localities (Pletzboden, Tölzer Hütte and Sattelgraben; Fig. 2) were studied or are under study, with sections of the uppermost Eiberg, Tiefengraben, and Breitenberg members. Macro- and microfaunas are very similar to those of the southern flank. A fragment of $P$. spelae was found at the outcrop south of Tölzer Hütte.

In the eastern Eiberg Basin the Eiberg quarry $\left(47^{\circ} 33^{\prime} / 12^{\circ} 10^{\prime}\right)$ exhibits an excellent outcrop from the Tiefengraben Member down to a complete Eiberg Member that is topped by a rather shaly, thinly laminated and pyrite-bearing $25 \mathrm{~cm}$ thick T-Bed with Choristoceras marshi and rich in fish scales and small bivalves. Microfaunas of the Tiefengraben Member are very similar to those of the Karwendel Syncline but part of the Schattwald Beds and the lower part of the Tiefengraben Member are missing by tectonics. The Möserer Alm/ Steinplatte section $\left(47^{\circ} 38^{\prime} 20^{\prime \prime} / 12^{\circ} 35^{\prime} 0^{\prime \prime}\right)$ has a more calcareous TBed up to $30 \mathrm{~cm}$ thick, containing common bivalves and, in the top black bituminous centimeter, Choristoceras marshi and Rhaetites $\mathrm{cf}$. gigantogaleatus. There is unfortunately no continuation upwards to the Tiefengraben Member.

The Kendlbach $\left(47^{\circ} 41^{\prime} 15^{\prime \prime} / 13^{\circ} 21^{\prime} 30^{\prime \prime}\right)$ section provided up to now, together with the nearby Tiefengraben, the most complete macroand micropalaeontological as well as palynological and geochemical data sets for the Northern Calcareous Alps, thanks to the detailed studies of Golebiowski and Braunstein (1988), Hallam (1990), Krystyn et al. (2005), and Kürschner et al. (2007). This easternmost and marginal section of the Eiberg Basin differs in the absence (respectively reduction to the $1 \mathrm{~cm}$ bituminous top layer) of the Kössen T-Bed due to non-deposition or erosion, in a comparatively reduced Tiefengraben Member (13 m) with common limestone intercalations but without ammonites, and in replacement of the reddish Schattwald Beds by black clays.

\section{Northwestern Europe (Fig. 27)}

St. Audrie's Bay, Somerset, England was proposed by Warrington et al. (1994) as GSSP for the base of the Hettangian and bed 13 (thought to represent the FO of the genus Psiloceras - at that time $P$. planorbis) defined as stratotype point (Hounslow et al., 2004). Later results (Bloos and Page, 2000) demonstrated, however, that the oldest psiloceratid of Northwestern Europe (Great Britain) is Psiloceras erugatum with the FO in bed 8 at Doniford Bay (near St. Audrie's Bay) followed closely above by Psiloceras planorbis in the upper part of bed 9. Though P. erugatum has inner whorls with nodes ("Knötchenstadium") like most Psiloceras specimens of the NCA, it was not yet found there and therefore it cannot be integrated into the Alpine Psiloceras succession. Considering the more or less pronounced ribbing of the inner whorls and the occurrence closely below Neophyllites in Northwestern Europe, P. erugatum should be younger than Psiloceras cf. pacificum from the Karwendel and older than the psiloceratids from the Calliphyllum Zone with Neophyllites as oldest ammonite (Bloos, 2004).

The Kuhjoch and Karwendel ammonites of the Tiefengraben Member (P. spelae to P. cf. pacificum) are not known from the barren lower "pre-Planorbis Beds" of England. The carbon isotopic signal is an additional correlation tool (Kürschner et al., 2007). The boundary should be expected to occur in the lowest few meters of the Blue Lias Formation (Fig. 27).

The similarity of the Hettangian microfauna (mostly ostracods and in part foraminifers, mainly nodosariids - polymorphinids) between the NCA and Northwestern Europe is not very helpful as long as in the latter the stratigraphically more important aragonitic Robertinina are not well documented. An exact correlation with the help of C-isotopes seems to be difficult.

The boundary definition at Kuhjoch was chosen because it enables a correlation between the marine and the terrestrial realm. The T-J boundary marks a significant biotic event in both realms. Palynological markers for the base of the Jurassic potentially enable correlation between terrestrial and marine sedimentary records and recognition of the T-J boundary in the continental realm. However, definition of terrestrial palynomorph markers for the base of the Jurassic in the studied marine sedimentary records is not straightforward. No major microfloral break has been found to be precisely contemporaneous with the T-J definition. A few notable LO and FO bio-events have, however, been found to characterize the T-J boundary interval, besides quantitative changes in the terrestrial pollen assemblages. These first and latest occurrences can be used for the correlation outside the Alpine realm. Typical Triassic palynomorph assemblages (e.g. Lunatisporites rhaeticus, Ovalipollis pseudoalatus and Rhaetipollis germanicus, Triancoraesporites spp.) are still present in the Kössen Formation and the Schattwald Beds. The records of these taxa show that they disappear at the top of the RPo zone. In St. Audrie's Bay (UK), the LO of these taxa is at the top of the Cotham Mb. of the Lilstock Fm. although they do not disappear exactly synchronously at this level (Warrington et al., 1994; Hounslow et al., 2004; Warrington, 2005; Bonis et al., 2010b).

There is no major palynofloral turnover that correlates precisely with the level of the T-J boundary as defined by the first occurrence of the ammonite Ps. spelae tirolicum. The only post-Triassic miospores with FO close to the base of the Jurassic, but $2 \mathrm{~m}$ below the entry level of Ps. spelae tirolicum, are Cerebropollenites thiergartii and Ischyosporites variegatus (see also discussion in Kürschner and Herngreen, 2010; Cirilli, 2010). C. thiergartii occurs within the turn to more negative $\delta^{13} \mathrm{C}$ values in the lower part of the main carbonisotope excursion, well above the extinction level of Triassic biota but significantly below the lowest occurrence of the first Jurassic ammonite. Bonis et al. (2010b) reported C. thiergartii and I. variegatus about $4 \mathrm{~m}$ above the base of the Blue Lias Fm. in St. Audrie's Bay. 


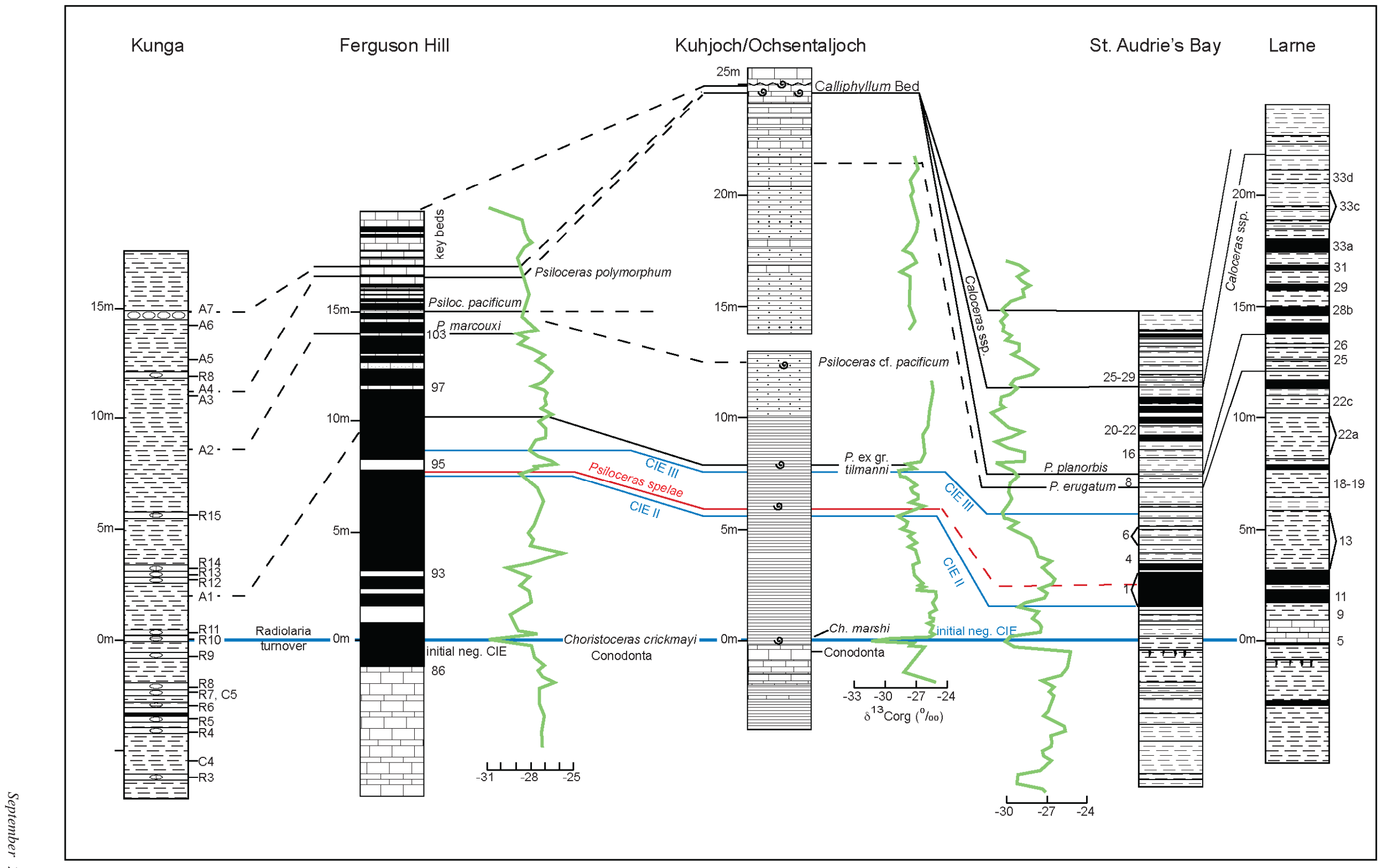

Figure 27. Correlation of GSSP Kuhjoch with the other sections proposed for the T-J boundary and correlation of $\boldsymbol{\delta}^{13} C_{\text {org }}$ curve (equal vertical scale). 
Fisher and Dunay (1981) reported C. thiergartii in the Watchet area at the top of Richardson's (1911) Paper Shale in the lower part of the Blue Lias. Moreover, $C$. thiergartii has been reported from lowermost Liassic sediments in the Germanic Triassic Basin in the Mariental core 1 (van de Schootbrugge et al., 2009; Heunisch et al., 2010) and in the Kamien Pomorski core in Poland (Pienkowsky et al., 2012), in high latitudes, Greenland (Pederson and Lund, 1980; Mander et al., 2010, 2013) and Sverdrup Basin (Suneby and Hills, 1988) and in the central Tethys realm, the Alborz Mountains in Iran (Achilles et al., 1984).

However, in the eastern North America basins there is presently no palynological event known that correlates with the T-J boundary. The prominent palynofloral turnover, which marks the base of the Classopollis pollen assemblage zone, appears to be of latest Rhaetian age (e.g. Whiteside et al., 2010 and further discussion below). For the southern hemisphere palynostratigraphic subdivisions of the Late Triassic and T-J transition have been documented in a number of palynological studies in Australia (e.g. Dolby and Balme, 1976; Helby et al., 1987; Brenner, 1992; Backhouse and Balme, 2002; Grice et al., 2005). In this region, Hettangian pollen assemblages are dominated by Classopollis. But a correlation of the base of this Classopollis torosus zone with the T-J boundary level as defined by the FAD of Ps. spelae is not well constrained. By contrast, in New Zealand an acme of Classopollis is not present but the lowermost Jurassic pollen zone, the Hettangian Retritriletes austroclavatidites zone is mainly dominated by spores (De Jersey and Rain, 1990). Also in this region the exact correlation of the base of this pollen zone with the T-J ammonoid biochronology is yet not well constrained (De Jersey and Rain, 1990). However, several palynological studies (e.g, Foster et al., 1994; Buratti and Cirilli, 2007) showed that Late Triassic microfloral assemblages alongside the western Tethys margin show some characteristic similarities with the microfloral assemblages in the NW-Australia described as the Onslow microflora by Dolby and Balme (1976). Therefore it may be possible to establish supra-regional palynostratigraphic correlations across the T-J transition but further detailed fine resolution studies are needed.

\section{Central Atlantic Magmatic Province (CAMP) and T-J boundary}

During the past years, evidence has been collected supporting the idea that the end-Triassic biotic crisis is linked with the environmental changes associated with a major volcanic event, the Central Atlantic Magmatic Province (e.g. Blackburn et al., 2013, Bonis and Kürschner, 2012; Deenen et al., 2011; Marzoli et al, 2004, 2006, 2008, 2011; Ruhl et al., 2011; Whiteside et al., 2007, 2008, 2010). Radiometric dating of both events resulted in corresponding ages. The CAMP is an extensive and relatively short magmatic event. In particular the Newark Basin and other basins of northeastern North America and basins of Northwestern Morocco provided many data and were studied in detail. Correlations between the different CAMP basins and marine basins were made, which differ in part (Deenen et al., 2011; Marzoli et al., 2008, 2011; Whiteside et al., 2007, 2008, 2010). Deenen et al. (2010, 2011) elaborated a detailed Trans-Atlantic CAMP correlation using cyclostratigraphy, palaeomagnetism, basalt geochemistry, and carbon isotope chemistry. Besides a correlation between the terrestrial and marine (United Kingdom) realm, a chronostratigraphic time frame for the end-Triassic extinction was provided. Deenen et al. (2011) concluded that the onset of CAMP started earlier (20 ka) in Morocco as found in the North American Newark Basin and the initial $\delta^{13} \mathrm{C}_{\text {org }}$ shift (extinction level) (= ICIE) can be traced from the marine to the terrestrial realm and is found in the topmost sediments below the base of the oldest Moroccan basalt. The T-J boundary is located by Deenen et al. (2011) $120 \mathrm{ka}$ above the initial isotope shift. The main period of CAMP magmatism is suggested to extend over $\sim 1.5 \mathrm{Ma}$ (Nomade et al., 2007). A longer duration for volcanism is affirmed by Verati et al. (2007) for Morocco as compared for North America. Blackburn et al. (2013) presented new geochronologic data on the age and duration of the T-J volcanism within CAMP. Seven sites in eastern North America and one in Morocco were investigated. The chronology proved the synchroneity between the earliest volcanism and terrestrial extinction. The release of magma occurred in four pulses over about $600 \mathrm{ka}$. The astrochronologic time scale is said to be proved. The oldest CAMP volcanites are said to be found in Morocco. The terrestrial end-Triassic extinction is dated with $201.564 \mathrm{ka}$. An exact radiometric date seems to be realistic to within $100 \mathrm{ka}$. An exact biostratigraphic correlation between terrestrial and marine realms up to now is not possible (Blackburn et al, 2013).

\section{a) Eastern North America}

The Newark Supergroup is developed in several rift basins along the eastern coast of the United States, which were formed in Late Triassic and Early Jurassic times when the Atlantic began to open. The Newark Supergroup consists of fluvial sediments with lacustrine and volcanic intercalations. Basalts of the Central Atlantic Magmatic Province (CAMP) start in the topmost Triassic or lowermost Jurassic, depending on presumed correlations (Schoene et al., 2010).

The Newark Supergroup is extremely thick (up to 6 kilometers). Although dinosaur footprints are common, body fossils of terrestrial vertebrates are rare. In lacustrine sediments, fossil fishes are sometimes frequent. Palynomorphs and conchostracans were used as biostratigraphic tools. Until a few years ago, the T-J boundary was drawn immediately below the first basalt flow with the beginning of the palynofloral C. meyeriana zone (Cornet, 1977). Recently, the integration of new cyclostratigraphic, palaeomagnetic, geochemical and palynological evidence has been used to constrain the position of the T-J boundary in the Newark Basin (Lucas et al., 2007; Deenen et al., 2010; Ruhl et al., 2010b). The new data indicate that the T-J boundary is positioned between the Orange Mt./Talcott and the Preakness/Holyoke basalts in the continental Newark and Hartford basins. These findings are in agreement with biostratigraphic data based on conchostracans, which are said to fix the T-J boundary at the base of the Bulbilimnadia sheni zone, which lies within the Newark extrusive zone (Kozur and Weems 2005, 2010) and palynological data from the Fundy Basin (Cirilli et al., 2009). Investigations on radioisotopes from a basal basalt yielded an age of 201.27 $\pm 0.06 \mathrm{Ma}$ (Schoene et al., 2006) and more recently of 200.1 $\pm 0.9 \mathrm{Ma}$ (Jourdan et al., 2009). New radiometric data of the Newark and Culpeper basins were presented by Marzoli et al. (2011, fig. 2). The Orange Mt. basalt (lowest volcanite of the Newark Basin) was dated with a radioisotopic age of 201.6 \pm 1.4 .Ma and an intruded sill of this basalt was dated by Blackburn et al. (2013) with an age of $201.52 \pm 0,034$ Ma. Cirilli et al. (2009, fig. 2) correlated the different basins of eastern North America. A correlation of the Newark Basin and marine T-J sections was also provided by Whiteside et al. (2010). 


\section{b) Morocco}

The CAMP volcanics of the Argana Valley and the Central High Atlas of Morocco are underlain by a thick continental clastic succession of cyclical playa sediments where red beds predominate. In the upper part (described in detail by Hofmann et al., 2000) the cycles commonly comprise ephemeral lakes or dry playa mudflat deposits, saline mudflat mudstones, overlain by sheet flows and aeolian sandstones. Four basaltic units are distinguished: The end Triassic extinction and and the first basaltic lava flow are said to be isochronic according to Blackburn et al. (2013). The third lava flow was dated with $201.564 \pm 0.054$ Ma.

Palynomorphs immediately below the lower basalt were dated by Cirilli et al. (2009) as probably Jurassic and the T-J boundary was drawn with question mark at this level. Deenen et al. (2010) also studied the palynomorphs of the Argana Basin and came to the result that due to the very low number and poor preservation of the palynomorphs they are of limited use for correlation purposes. Hofmann et al. (2000, fig. 7) indicate conchostracans, which perhaps may be of use for a correlation with North America (Kozur and Weems, 2005, 2010).

\section{Western Americas (Figs. 22, 27)}

\section{a) North America}

T-J boundary sections with the most complete ammonite record were described from the New York Canyon (Nevada, USA) (Guex, 1995; Guex et al., 1997, 1998, 2002, 2003; Lucas and Tanner, 2007). The sections were proposed in various ways as T-J boundary GSSP (initial negative isotope excursion: McRoberts et al., 2007 or the FO of Psiloceras: Guex et al., 1998, 2009).

The proposed GSSP horizon of Guex et al. (1998) with the FO of Psiloceras spelae spelae as boundary event can be correlated with ammonite level (2) of the Karwendel syncline. Ammonite levels (3a and b) of Kuhjoch and especially Ochsentaljoch probably have no counterpart in Nevada. The beds with Choristoceras minutum, Odoghertyceras deweveri, Psiloceras marcouxi, P. tilmanni and cf. Neophyllites $7.2 \mathrm{~m}$ above $P$. spelae may be correlated with ammonite level (4), $6 \mathrm{~m}$ above $P$. spelae tirolicum at Kuhjoch but choristoceratids and psiloceratids similar to Psiloceras marcouxi do not occur in the Hettangian of Europe, and the determination of the Neophyllites (without suture line and whorl section not preserved) is doubtful. Ammonite level (4a) of the Hochalplgraben section probably lies in the range of the beds with Psiloceras pacificum in Nevada. The pelecypod Agerchlamys occurs slightly earlier than Psiloceras spelae mirroring the situation in the NCA. Hettangian microfossils of biostratigraphic value were not yet found-in the Nevada sections.

The section underwent contact metamorphism and it is not clear how much the $\delta^{13} \mathrm{C}_{\text {org }}$ curve may have been affected and/or changed.

Carter and Tipper (1999) proposed another candidate GSSP for the T-J boundary in a section at Kunga Island (Queen Charlotte Islands, Canada) where the base of the Jurassic was defined by the first occurrence of Hettangian radiolarians of the Canoptum merum zone (Carter and Hori, 2005). Any exact correlation with other fossil groups (e.g. ammonites) is impossible over an interval from $15 \mathrm{~m}$ below to about $6 \mathrm{~m}$ above the proposed boundary level. A concomitant and pronounced negative $\delta^{13} \mathrm{C}_{\text {org }}$ anomaly is used as correlation tool to other sections (Ward et al., 2007.

\section{b. South America (Fig. 22)}

The Chilingote section in the Utcubamba valley of Northern Peru was proposed as GSSP candidate for the T-J boundary (Hillebrandt, 1997; the proposal was withdrawn 2006). At Chilingote, the first Hettangian ammonite bed is characterized by a species of Psiloceras, which is distinguished from Psiloceras tilmanni by a steeper umbilical wall. In this bed, Odoghertyceras also occurs. Below this bed, radiolarians transitional to basal Hettangian forms occur with just a few Rhaetian holdovers. Probably the radiolarian turnover is older than the ammonite turnover (Lucas et al., 2005). Above follow several beds with Psiloceras tilmanni s.str.

There are other complete T-J boundary sections in the Utcubamba valley (Hillebrandt, 2000a) but ammonites are mostly compressed and not yet studied in detail. Recently (Schaltegger et al., 2008) discovered Psiloceras cf. spelae near a section described by Hillebrandt (1994, 2000a). Psiloceras cf. spelae (unfortunately compressed) was found above Choristoceras crickmayi and $10 \mathrm{~m}$ below Psiloceras tilmanni. The Utcubamba valley eventually could provide a correlation of ammonite and radiolarian biostratigraphy within the boundary interval. Schaltegger et al. (2008), Schoene et al. (2010), and Guex et al. (2012) dated several ash beds in this section and state an age for the base of the Jurassic between $201.35 \pm 0.10$ and 201.26 $\pm 0.13 \mathrm{Ma}$.

Other T-J boundary sections are found in northern Chile (Hillebrandt, 2000a) but earliest Hettangian ammonites are missing. The oldest ammonite level (Primocostatum Zone in Hillebrandt, 2000b) can be correlated with a part of the Psiloceras polymorphum Zone in Nevada and the Planorbis and Calliphyllum zones in Europe (Fig. 22).

\section{Tibet}

Yin et al. (2007) described from southern Tibet (Germig) two sections rich in megafossils. Ammonite beds allow a detailed biostratigraphic subdivision in Late Triassic (Rhaetian) and Early Jurassic (Hettangian) ammonite zones and subzones. Two nearby sections (A and B) were measured and correlated. The Late Rhaetian Marshi Zone was proved with different species of Choristoceras and Eopsiloceras (level B1). Above this zone was distinguished a zone named Tibeticum Zone and said to be of earlied Hettangian age. Level B2 (section B) is located some meters above level B1 and contains a new species of Choristocers (C. nyalamense) and a small specimen determined as Neophyllites sp.indet..This specimen has a corroded suture line and also could be a Psiloceras. In the authors (A.v.H.) opinion level B2 with $C$. nyalamense belongs to the Late Rhaetian Marshi Zone. Level A1 (section A) of this zone is characterized by the new species Psiloceras tibeticum, Rhacophyllites and a specimen determined as Eopsiloceras. This specimen is a latex cast without suture line and difficult to determine, even on generic level. $P$. tibeticum belongs to the $P$. calliphyllum group with deeply indentated and retracted suture lines. The Tibetian level A1 is the first ammonite horizon of Jurassic age but $P$. tibeticum does not belong to the oldest Psiloceras like $P$. spelae or the $P$. tilmanni group. One meter above level A1 was found level A2 with Neophyllites cf. biptychus, a genus found in NW Europe below P. planorbis. Levels with P. calliphyllum occur in Germig at both sections. This species characterizes the Calliphyllum bed of the NCA and lies at the GSSP $18 \mathrm{~m}$ above the T-J boundary. At Germig is missung the entire Tilmanni Zone. 


\section{Isotope and Cyclo-Stratigraphy (written by $M$.} Ruhl and W.M. Kürschner)

The sedimentary sequence of the Rhaetian Kössen Fm. is marked by a distinct change from alternating limestone beds and marls to clays and marls. In the western Eiberg Basin the cyclicity of the Kössen Formation has been described in the Eiberg quarry based on palynological data but no frequency analysis was applied (Holstein, 2004). Cyclostratigraphic analysis of the T-J boundary interval has not been performed because long continuous outcrops suitable for quantitative cyclostratigraphic analysis have not yet been found in the Eiberg Basin. However, physical and chemical proxy records covering the uppermost Triassic and lowermost Jurassic marine successions of St. Audrie's Bay and East Quantoxhead (UK) have been used to establish a floating astronomical time-scale of about 2.5 Ma (Ruhl et al., 2010b). Based on these findings, the extinction interval coinciding with the initial negative $\mathrm{C}$-isotope excursion represents $1-2$ precession cycles (about 20-40 ka), while the recovery interval preceeding the first Jurassic ammonite is confined to 6 precession cycles (about $120 \mathrm{ka}$ ). These findings are in agreement (within the analytical error) with radiometric age assessments of ash beds in T-J boundary sections in Peru and N-America (Schoene et al., 2010).

Several studies (Kürschner et al., 2007; Bonis et al., 2009; Ruhl et al., 2009) have confirmed the use of C-isotope stratigraphy for high-resolution correlation of T-J boundary sections within the Eiberg Basin. The interval of the end-Triassic mass extinction is characterized by a distinct negative $\mathrm{C}$-isotope excursion, which is also referred to the initial negative carbon isotope excursion. Correlation of the Cisotope record across the extinction interval in marine records of the Eiberg Basin to St. Audrie's Bay (UK) (Kürschner et al., 2007; Ruhl et al., 2009; Ruhl and Kürschner, 2011) and outside Europe (Guex et al., 2004; Ward et al., 2007) is relatively straightforward. The base of the Hettangian, as defined by the FO of Ps. spelae tirolicum, coincides with a second, longer lasting 'main' negative C-isotope excursion, which can be used as an independent correlation tool.

\section{Palaeobiogeography}

Around the T-J boundary, the NCA underwent a distinct change in their palaeobiogeographic relations from a typical Tethyan to an intermediate position between Tethys and Northwestern Europe. The NCA (including the Eiberg Basin) were then situated between the Euroboreal Realm of Northwestern Europe and the Tethyan Realm of the Mediterranean and were differentiated as an Austroalpine Province before the opening of the Ligurian-Penninic ocean and the separation of the Adriatic microplate (Blau, 1998). Choristoceras is a typical low palaeolatitude Tethyan-Panthalassian faunal element and the psiloceratids of the Tiefengraben Member must also have immigrated from the Tethyan Realm since they are not found in northwestern Europe. Only a direct faunal exchange between the western Tethys and the Panthalassa Ocean can explain the presence of the East Pacific ammonites (Psiloceras spelae, Psiloceras cf. pacificum) in the Alps. The first obvious ammonite links to the Euroboreal are younger and date to the time of the Calliphyllum Zone. The bivalve Agerchlamys is found in the Tethyan Realm and the East Pacific Province. Ostracods and foraminifers show relations to the Tethyan and the Euroboreal Realm. Calcareous nannoplankton is not suitable for biogeographic comparisons as it is unknown from the pre-Planorbis Beds of England as well as from coeval sediments of the eastern Tethyan Realm and the East Pacific Province.

\section{Conclusions}

The selected Global Stratotype Section and Point matches the requirements of ICS for a GSSP. The Kuhjoch section offers not only a well-exposed boundary section but also an outcrop with a continuous sequence of sediments of Late Triassic and Jurassic age, which is some hundreds of meters thick. The proposed T-J boundary section ( $25 \mathrm{~m}$ thick) shows a high sedimentation rate with continuous sedimentation and no condensation in the proximity of the boundary level. The sedimentation rate is high enough to show well-separated short-lived successive events. Synsedimentary disturbances are missing and only minor tectonic overprint disrupts the sedimentary sequence. The fossils are very well preserved (aragonitic shells) and different groups of macro- and microfossils are found indicating a well-oxygenated, open marine environment. No vertical facies changes affect the boundary level. The boundary can be traced over $10 \mathrm{~km}$ parallel to the strike of the basin and some kilometers vertical to its axis. The primary boundary marker (P. spelae) has a low palaeolatitude global distribution and a short vertical range. Other fossil groups (bivalves, foraminifers, ostracods, dinoflagellates) allow correlation with marine sections where ammonites are lacking. Finally, terrestrial palynomorphs (FO of Cerebropollenites thiergartii and Ischyosporites variegatus) bridge the barrier to the non-marine realm. A welldifferentiated ${ }^{13} \mathrm{C}_{\text {org }}$ curve with two pronounced excursions provides additional constraints for correlation with other T-J boundary sections.

Table 1: Summary of the requirements of the International Commission on Stratigraphy for the Kuhjoch Section as base of the Jurassic (T/J boundary) and candidate GSSP.

\begin{tabular}{|l|l|}
\hline $\begin{array}{l}\text { The requirements for a } \\
\text { GSSP (ICS) }\end{array}$ & $\begin{array}{l}\text { Kuhjoch Section } \\
\text { (Western Karwendel, } \\
\text { Tyrol, Austria) }\end{array}$ \\
\hline GEOLOGICAL REQUIREMENTS \\
\hline Exposure over an adequate thickness & Yes \\
\hline $\begin{array}{l}\text { Continuous sedimentation. No gaps or } \\
\text { condensation close to the boundary }\end{array}$ & Yes \\
\hline Rate of sedimentation & $\begin{array}{l}\text { At least } 50 \text { cm for spelae horizon } \\
\text { and } 10 \text { m for Tilmanni Zone }\end{array}$ \\
\hline $\begin{array}{l}\text { Absence of synsedimentary and tectonic } \\
\text { disturbances near boundary level }\end{array}$ & Yes \\
\hline $\begin{array}{l}\text { Absence of metamorphism and strong } \\
\text { diagenetic alteration }\end{array}$ & Yes \\
\hline BIOSTRATGRAPHIC REQUIREMENTS & \multicolumn{2}{|l|}{} \\
\hline $\begin{array}{l}\text { Abundance and diversity of well } \\
\text { preserved fossils }\end{array}$ & Yes \\
\hline $\begin{array}{l}\text { Absence of vertical facies changes at or } \\
\text { near the boundary }\end{array}$ & Yes \\
\hline $\begin{array}{l}\text { Favorable facies for long-range } \\
\text { biostratigraphic correlations }\end{array}$ & Yes \\
\hline OTHER METHODS & Yes (at section Kuhjoch East) \\
\hline Radio-isotopic dating & Yes, driving permit from \\
\hline Magnetostratigraphy & Oesterreichische Bundesforste \\
\hline Chemostratigraphy & No information \\
\hline (Karwendel Naturpark)
\end{tabular}




\section{Acknowledgements}

We are thankful to the Österreichische Bundesforste AG for gaining access to the forest roads of the studied area. We are very thankful to M. Margreiter who let at disposition the fenced parcel of the GSSP. We thank the Austrian ministry of sciences and the Austrian National Comittee for Geosciences, in particular Prof. W. Piller for finance of the excavation carried out cautiously by H.G. Tschappeler GmBH, Lienz. This is a contribution to IGCP 458 and 467 with L.K. and S.R. sponsored by the Austrian National Committee (Austrian Academy of Sciences) for IGCP. R. Golebiowsky (Vienna) provided personal field notes and stimulating discussions. W.M.K., N.R.B., M.R., M.D., M.A.N.S. and W.K. gratefully acknowledge financial support from the HP program of Utrecht University (The Netherlands). C.A.M. acknowledges partial support from the US National Science Foundation (Grant EAR 0518605). We are very thankful to all those colleagues supporting our investigations with discussions and advices, mainly Gert Bloos, Jean Guex, Nicol Morton, Stan Finney and Jim Ogg. A.v.H. received generous support by the Institute of Applied Geosciences (Technical University Berlin) and Prof. Dr. Dominik to use the facilities of his institution. The photographs of macrofossils were made by B. Kleeberg, the drawings and also photo works by Mrs. H. Glowa, additional drawings by Mrs. B. Dunker and Mrs. G. Ogg. The SEM photographs of microfossils were taken by Mr. J. Nissen (Zentraleinrichtung Elektronenmikroskopie, TU Berlin). M.U. thanks Dr. R. Böttcher (Stuttgart) for assistance of the drawings. We are grateful to three reviewers for suggestions to improve the manuscript.

\section{References}

Achilles, H., Kaiser, H., and Schweitzer, H., 1984, Die Mikroflora der obertriadisch-jurassischen Ablagerungen des Alborz-Gebirges (NordIran): Palaeontographica, ser. B, v. 194, pp. 14-95.

Ainsworth, N.R. and Boomer, I., 2009, Triassic: In Whittaker, J.E. and Hart, M.B., eds, Ostracods in British Stratigraphy. The Micropalaeontological Society, special publications: London, Micropalaeontological Society, pp. 165-174.

Ampferer, O. and Ohnesorge, T., 1912, Geologische Karte 1 : 75 000, Blatt 29: Innsbruck und Achen-See, Wien, Geologische Bundesanstalt.

Backhouse, J. and Balme, B.E., 2002, Late Triassic palynology of the Northern Carnavon Basin: Minerals and Energy Research Institute of Western Australia, Report No. 266, pp. 1-168.

Batten, D.J., 2002, Palynofacies and petroleum potential. In: Jansonius, J. and McGregor, D.C. (eds.): Palynology: Principles and Applications, vol. 3 ( $2^{\text {nd }}$ edition): American Association of Stratigraphic Palynologists Foundation: pp. 1065-1084.

Blackburn, T.J., Olsen, P.E., Bowring, S.A., McLean, N.M., Kent, D.V., Puffer, J., McHone, G., Rasbury, E.T. and Et-Touhami, M., Zircon U-Pb Geochronology Links the End-Triassic Extinction with the Central Atlantic Magmatic Province: Science, v. 340, pp. 941-945.

Blau, J., 1998, Monographie der Ammoniten des Obersinemuriums (Lotharingium, Lias) der Lienzer Dolomiten (Österreich): Biostratigraphie, Systematik und Paläogeographie: Revue de Paléobiologie, Genève, v. 17, pp. 177-285.

Blind, 1963, Die Ammoniten des Lias alpha aus Schwaben, vom Fonsjoch und Breitenberg (Alpen) und ihre Entwicklung: Palaeontographica, ser. A, v. 121, pp. 38-131.

Bloos, G., 2004, Psiloceratids of the earliest Jurassic in the North-West European and Mediterranean Provinces - Remarks and new observations: Stuttgarter Beiträge zur Naturkunde, ser. B, no. 347, pp. 1-15.

Bloos, G. and Page, K.N., 2000, The Basal Jurassic Ammonite Succession in the North-West European Province: Review and New Results: GeoResearch Forum, v. 6, pp. 27-40.

Bökenschmidt, S. and Zankl, H., 2005, Lithology, biostratigraphy and sedimentary petrology of the T-J boundary section in the Steinplatte and Scheibelberg area (Salzburg - Tirol, Austria: In Palfy, J. and Oszvart, P., eds, $5^{\text {th }}$ Field Workshop, IGCP 458 Project, Triassic-Jurassic Boundary Events: Tata and Hallein, pp. 10-11.

Bonis, N.R., Kürschner, W.M., and Krystyn, L., 2009, A detailed palynological study of the Triassic-Jurassic transition in key sections of the Eiberg Basin (Northern Calcareous Alps, Austria): Review of Palaeobotany and Palynology, v. 156, pp. 376-400.

Bonis, N.R., Ruhl, M., and Kürschner, W.M., 2010a, Climate change driven black shale deposition during the end-Triassic in the western Tethys: Palaeogeography, Palaeoclimatology, Palaeoecology, v. 290, pp. 151-159.

Bonis, N.R., Ruhl, M., and Kürschner, W.M, 2010b, Milankovitch-scale palynological turnover across the Triassic-Jurassic transition at St. Audrie's Bay, SW UK: Journal of the Geological Society, v. 167, pp. 877-888.

Bonis, N.R. and Kürschner, W.M., 2012, Vegetation history, diversity patterns, and climate changes across the Triassic/Jurassic boundary: Paleobiology, v. 38 , pp. 240-264.

Brandner, R. and Gruber, A., 2011, Exkursion E 2a - Rofangebirge: In Gruber, A., ed, Arbeitstagung 2011 der Geologischen Bundesanstalt Blatt Achenkirch, pp. 149-167.

Brenner, W., 1992, First results of Late Triassic palynology of the Wombat Plateau, NW Australia. In Haq, B.U., von Rad, U., O’Connell, S., and others (eds.): Proceedings of the Ocean Drilling Program Scientific Results Initial Reports, v. 122, pp. 413-426.

Buratti N. and Cirilli, S., 2007, Microfloristic provincialism in the Upper Triassic Circum-Mediterranean area and palaeogeographic implication: Geobios, v. 40, pp. 133-142.

Carter, E.S. and Hori, R.S., 2005, Global correlation of the radiolarian faunal change across the Triassic Jurassic boundary: Canadian Journal of Earth Sciences, v. 42, pp. 777-790.

Carter, E.S. and Tipper, H.W., 1999, Proposal of Kunga Island, Queen Charlotte Islands, British Columbia, Canada as Triassic/Jurassic global boundary stratotype: International Subcommission on Jurassic Stratigraphy Newsletter, v. 27, p. 20.

Cirilli, S., 2010, Upper Triassic - lowermost Jurassic palynology and palynostratigraphy: a review: In Lucas, S.G., ed, The Triassic Timescale: Geological Society London Special Publications, v. 334, pp. 285-314.

Cirilli, S., Marzoli, A., Tanner, L., Bertrand, H., Buratti, N., Jourdan, F., Bellieni, G., Kontak, D., and Renne, P.R., 2009, Latest Triassic onset of the CAMP volcanism in the Fundy Basin (Nova Scotia): new stratigraphic constrains: Earth and Planetary Science Letters, v. 286, pp. 514-525.

Cornet, B., 1977, The palynostratigraphy and age of the Newark Supergroup. Ph.D. Thesis. Pennsylvania State University, University Park, PA. $505 \mathrm{pp}$.

De Jersey, N.J. and Raine, J.I., 1990, Triassic and earliest Jurassic miospores from the Murihiku Supergroup, New Zealand: New Zealand Geological Survey Paleontological Bulletin, v. 62, pp. 1-164.

Deenen, M.H.L., Krijgsman, W., and Ruhl, M., 2011, The quest for chron E23r at Partridge Island, Bay of Fundy, Canada: CAMP emplacement postdates the end-Triassic extinction event at the North American craton: Canadian Journal of Earth Sciences, v. 48, pp. 1282-1291.

Deenen, M.H.L., Ruhl, M., Bonis, N.R., Krijgsman, W., Kürschner, W.M., Reitsma, M., and van Bergen, M.J., 2010, A new chronology for the endTriassic mass extinction: Earth and Planetary Science Letters, v. 291, pp. 113-125.

Dolby, J.H. and Balme, B.E., 1976, Triassic palynology of the Carnarvon Basin, Western Australia: Review of Palaeobotany and Palynology, v. 22, pp. 105-168.

Fabricius, F.H., 1960, Sedimentation und Fazies des Rät und der Lias Überdeckung in den Bayrisch-Tiroler Kalkalpen: Dissertation summary TH München, 16 pp.

Fabricius, F.H., 1966, Beckensedimentation und Riffbildung an der Wende 
Trias/Jura in den Bayerisch-Tiroler Kalkalpen: International Sedimentary Petrographical Series, v. 9, 143 pp.

Fisher, M.J. and Dunay, R.E., 1981, Palynology and the Triassic/Jurassic boundary: Review of Palaeobotany and Palynology, v. 34, pp.129-135.

Foster, C.B., Balme, B.E. and Helby, R., 1994, First record of Tethyan palynomorphs from the Late Triassic of east Antarctica: AGSO Journal of Australian Geology and Geophysics, v. 15, pp.239-246.

Gallet, Y., Krystyn, L., Marcoux, J., and Besse J., 2007, New constraints on the End-Triassic (Upper Norian-Rhaetian) magnetostratigraphy: Earth and Planetary Science Letters, v. 255, pp. 458-470.

Golebiowski, R., 1986, Neue Misikellen-Funde (Conodonta) und ihre Bedeutung für die Abgrenzung des Rhät s.str. in den Kössener Schichten: Sitzungsberichte der Österreichischen Akademie der Wissenschaften, mathematisch-naturwissenschaftliche Klasse, Abt. I, v. 195, pp. 53-65.

Golebiowski, R., 1989, Stratigrafie und Biofazies der Kössener Formation (Obertrias - Nördliche Kalkalpen: unpublished thesis, Wien.

Golebiowski, R., 1990, Facial and faunistic changes from Triassic to Jurassic in the Northern Calcareous Alps (Austria): Cahiers Université Catholique Lyon, ser. Science, v. 3, pp. 175-184.

Golebiowski, R. and Braunstein, R.E., 1988, A Triassic/Jurassic boundary section in the Northern Calcareous Alps (Austria): Berichte der Geologischen Bundesanstalt, v. 15, pp. 39-46.

Grice, K., Backhouse, J., Alexander, R., Marschall, N., and Logan, G.A., 2005, Correlating terrestrial signatures from biomarker distributions, $\mathrm{d}^{13} \mathrm{C}$, and palynology in fluvio-deltaic deposits from NW Australia (Triassic-Jurassic): Organic Geochemistry, v. 36, pp. 1347-1358.

Guex, J., 1995, Ammonites hettangiennes de la Gabbs Valley Range (Nevada, USA): Mémoirs de Géologie Lausanne, v. 27, pp. 1-131.

Guex, J., Bartolini, A., and Taylor, D., 2002, Discovery of Neophyllites (Ammonitina, Cephalopoda, Early Hettangian) in the New York Canyon sections (Gabbs Valley Range, Nevada) and discussion of the $\ddot{a}^{13} \mathrm{C}$ negative anomalies located around the Triassic-Jurassic boundary: Bulletin de Géologie, Lausanne, v. 354, pp. 247-254.

Guex, J., Bartolini, A., Atudorei, V., and Taylor, D., 2003, Two negative $\ddot{a}^{13} \mathrm{C}_{\text {org }}$ excursions near the New York Canyon area (Gabbs Valley Range, Nevada): Bulletin de Géologie, Lausanne, v. 60, 4 pp.

Guex, J., Bartolini, A., Atudorei, V., and Taylor, D., 2004, High-resolution ammonite and carbon isotope stratigraphy across the Triassic-Jurassic boundary at New York Canyon (Nevada): Earth and Planetary Science Letters, v. 225, pp. 29-41.

Guex, J., Bartolini, A., Taylor, D., Atudorei, V., Thelin, P., Bruchez, S., Tanner, L., and Lucas S. 2009, Comment on: "The organic carbon isotopic and paleontological record across the Triassic-Jurassic boundary at the candidate GSSP section at Ferguson Hill, Muller Canyon, Nevada, USA" by Ward et al. 2007: Palaeogeography, Palaeoclimatology, Palaeoecology, v. 273 , pp. 200-204.

Guex, J., Rakus, M., Taylor, D., and Bucher, H., 1997, Proposal for the New York Canyon area, Gabbs Valley Range, Nevada, USA: International Subcommission on Jurassic Stratigraphy Newsletter, v. 24, pp. 26-30.

Guex, J., Rakus, M., Taylor, D., and Bucher, H., 1998, Deux nouveaux genres et quatre nouvelles espèces d'ammonites (Cephalopoda) du Lias inferieur: Bulletin de Géologie, Lausanne, v. 339, pp. 73-85.

Guex, J., Schoene, B., Bartolini, A., Spangenberg, J., Schaltegger, U., O’Dogherty, L., Taylor, D., Bucher, H., and Atudorei, V., 2012, Geochronological constraints on post-extinction recovery of the ammonoids and carbon cycle perturbations during the Early Jurassic: Palaeogeography, Palaeoclimatology, Palaeoecology, v. 346-347, pp. 111.

Hallam, A., 1990, Correlation of the Triassic-Jurassic boundary in England and Austria: Journal of the Geological Society v. 147, pp. 421-424.

Hallam, A. and Goodfellow, W.D., 1990, Facies and geochemical evidence bearing on the end-Triassic disappearance of the alpine reef ecosystem: Historical Biology, v. 4, pp. 131-138.

Hallam, A. and Wignall, P.B., 1999, Mass extinctions and sea-level changes: Earth-Science Reviews, v. 48, pp. 217-250.

Harloff, J. and Jäger, R., 1994, Ostracoden aus dem Lias der Kalkalpen Bayerns und Nordtirols: Stuttgarter Beiträge zur Naturkunde, ser. B, no. 205, pp. $1-63$.

Hautmann, M., 2004, Effect of end-Triassic CO2 maximum on carbonate sedimentation and marine facies: Facies, v. 50, p. 257-262.

Helby, R., Morgan, R., and Patridge, A.D., 1987, A palynological zonation of the Australian Mesozoic: Memoir of the Association of Australian Palaeontologists, v. 4, pp. 1-94.

Hesselbo, S.P., Robinson, S.A., Surlyk, F., and Piasecki, S., 2002, Terrestrial and marine extinction at the Triassic-Jurassic boundary synchronized with major carbon-cycle perturbation: a link to initiation of massive volcanism?: Geology, v. 30, pp. 251-254.

Heunisch, C., Luppold, F.W., Reinhardt, L., and Röhling, H.-G., 2010, Palynofazies, Bio- und Lithostratigrafie im Grenzbereich Trias/Jura in der Bohrung Mariental 1 (Lappwaldmulde, Ostniedersachsen): Zeitschrift der Deutschen Gesellschaft für Geowissenschaften, v. 161, pp. 51-98.

Hillebrandt, A.v., 1994, The Triassic/Jurassic Boundary and Hettangian Biostratigraphy in the Area of the Utcubamba Valley (Northern Peru): Geobios, M.S., v. 17, pp. 297-307.

Hillebrandt, A.v., 1997, Proposal of the Utcubamba Valley sections in Northern Peru: International Subcommission on Jurassic Stratigraphy, Newsletter, v. 24 , pp. $21-25$.

Hillebrandt, A.v., 2000a, Die Ammoniten-Fauna des südamerikanischen Hettangium (basaler Jura), Teil I. Palaeontographica, ser. A, v. 257, pp. $85-189$.

Hillebrandt, A.v., 2000b, Die Ammoniten-Fauna des südamerikanischen Hettangium (basaler Jura), Teil III: Palaeontographica, ser. A, v. 258, pp. 65-116.

Hillebrandt, A.v., 2008, Aragonitische Foraminiferen (Robertinina) aus dem Trias/Jura-Grenzbereich der Nördlichen Kalkalpen sowie ihre biostratigraphische und paläoökologische Bedeutung: 78. Jahrestagung der Paläontologischen Gesellschaft. Erlanger geologische Abhandlungen, Sonderband, v. 6, p. 34.

Hillebrandt, A.v., 2010, Aragonitic Foraminifera (Robertinina) from the Triassic-Jurassic boundary interval of the Northern Calcareous Alps: Earth Science Frontiers, v. 17, special issue, pp. 70-72.

Hillebrandt, A.v., 2012, Are the Late Triassic to Early Jurassic aragonitic Oberhauserellidae (Robertinina) the ancestors of planktonic Foraminifera: Neues Jahrbuch für Geologie und Paläontologie Abhandlungen, v. 266, pp. 199-215.

Hillebrandt, A.v. and Kment, K., 2009, Die Trias/Jura-Grenze und der Jura in der Karwendelmulde und dem Bayerischen Synklinorium: Exkursionsführer Deutsche Stratigraphische KommissionSubkommission für Jurastratigraphie, $45 \mathrm{pp}$.

Hillebrandt, A.v. and Kment, K., 2011, Lithologie und Biostratigraphie des Hettangium im Karwendelgebirge: In Gruber, A. (ed.): Arbeitstagung 2011 der Geologischen Bundesanstalt Blatt Achenkirch, pp. 17-38.

Hillebrandt, A.v. and Krystyn, L., 2007, Ein globaler Vergleich der ältesten Ammoniten des Jura: Faunenfolge und ihre Bedeutung für die Definition der Trias/Jura-Grenze: In Elicki, O. and Schneider, J.W., eds, Fossile Ökosysteme, 77. Jahrestagung der Paläontologischen Gesellschaft. Wissenschaftliche Mitteilungen, v. 36, pp. 54-55.

Hillebrandt, A.v. and Krystyn, L., 2009, On the oldest Jurassic ammonites of Europe (Northern Calcareous Alps, Austria) and their global significance: Neues Jahrbuch für Geologie und Paläontologie Abhandlungen, v. 253, pp. 163-195.

Hillebrandt, A.v., Kürschner, W.M, and Krystyn, L., 2007, A candidate GSSP for the base of the Jurassic in the Northern Calcareous Alps (Kuhjoch section, Karwendel mountains, Tyrol, Austria): In Bown, P., Morton, N., and Lees, J., eds., International Subcommission on Jurassic Stratigraphy ISJS Newsletter, v. 34, pp. 2-20.

Hillebrandt, A.v. and Urlichs, M., 2008, Foraminifera and Ostracoda from the Northern Calcareous Alps and the end-Triassic biotic crisis: Berichte der Geologischen Bundesanstalt, v. 76, pp. 30-38.

Hofmann, A., Tourani, A., and Gaupp, R., 2000, Cyclicity of Triassic to Lower Jurassic continental red beds of Argana valley, Morocco: Palaeogeography, Palaeoclimatology, Palaeoecology, v. 161, pp. 229-266. 
Holstein, B., 2004, Palynologische Untersuchungen der Kössener Schichten (Rät, Alpine Obertrias): Jahrbuch der Geologischen Bundesanstalt, v. 144, pp. 261-365.

Hounslow, M.W., Posen, P.E., and Warrington, G., 2004, Magnetostratigraphy and biostratigraphy of the Upper Triassic and lowermost Jurassic succession, St. Audrie's Bay, UK: Palaeogeography, Palaeoclimatology, Palaeoecology, v. 213, pp. 331-358.

Jourdan, F., Marzoli, A., Bertrand, H., Cirilli, S., Tanner, L.H., Kontak, D.J., McHone, G., Renne, P.R., and Bellieni, G., 2009, ${ }^{40} \mathrm{Ar} /{ }^{39} \mathrm{Ar}$ ages of CAMP in North America: Implications for the Triassic-Jurassic boundary and the ${ }^{40} \mathrm{~K}$ decay constant bias: Lithos, v. 110, pp. 167-180.

Karle, U., 1984, Palynostratigraphische Untersuchungen eines Rhaet/Lias Profils am Fonsjoch, Achensee (Nördliche Kalkalpen, Österreich): Mitteilungen der Österreichischen Geologischen Gesellschaft, v. 77, pp. 331-353.

Kment, K., 2000, Frühe liassische Ammoniten aus der Gegend um Hinterriß im Karwendelgebirge (Tirol) und dem Mangfallgebirge bei Rottach-Egern (Bayern): Jahrbuch der Geologischen Bundesanstalt, v. 142, pp. 181218.

Korte, C. and Kozur, H.W., 2011, Bio- and chemostratigraphic assessment of carbon isotope records across the Triassic-Jurassic boundary at Csõvár quarry (Hungary) and Kendlbachgraben (Austria) implications for global correlations: Bulletin of the Geological Society of Denmark, v. 59, pp. 101-115.

Kozur, H.W. and Mock, R., 1991, New Middle Carnian and Rhaetian conodonts from Hungary and the Alps. Stratigraphic importance and tectonic implications for the Buda Mountains and adjacent areas: Jahrbuch der Geologischen Bundesanstalt, v. 134, pp. 271-297.

Kozur, H.W. and Weems, R.E., 2005, Conchostracan evidence for a Late Rhaetian to early Hettangian age for the CAMP volcanic event in the Newark Supergroup, and a Sevatian (late Norian) age for the immediately underlying beds: Hallesches Jahrbuch für Geowissenschaften, ser. B, v. 27, pp. 21-51.

Kozur, H.W. and Weems, R.E., 2010, The biostratigraphic importance of conchostracans in the continental Triassic of the northern hemisphere: In Lucas, S.G., ed, The Triassic Timescale: Geological Society of London Special Publications, v. 334, pp. 315-417.

Krystyn, L., 1980, Triassic conodont localities of the Salzkammergut region (Northern Calcareous Alps). Second European Conodont Symposium (ECOS II): Abhandlungen der Geologischen Bundesanstalt, ser. A., v. 35, pp. 61-98.

Krystyn, L., Böhm, F., Kürschner, W.M., and Delecat, S., 2005, The TriassicJurassic boundary in the Northern Calcareous Alps: In Palfy, J. and Oszvárt, P.. eds, $5^{\text {th }}$ Field Workshop, IGCP 458 Project, Triassic-Jurassic Boundary Events, pp. A1-A39; Tata and Hallein.

Kürschner, W.M., Bonis, N.R., and Krystyn, L., 2007, Carbon-Isotope stratigraphy of the Triassic-Jurassic transition in the Tiefengraben section, Northern Calcareous Alps: Palaeogeography, Palaeoclimatology, Palaeoecology, v. 244, pp. 257-280.

Kürschner, W.M. and Herngreen, G.F.W., 2010, Triassic Palynology of Central and Northwest Europe: a review of palynofloral diversity patterns and biostratigraphic subdivisions: In Lucas, S. G., ed., The Triassic Timescale: Geological Society of London Special Publications, v. 334, pp. 263-283.

Lange, W., 1952, Der Untere Lias am Fonsjoch (östliches Karwendelgebirge) und seine Ammonitenfauna: Palaeontographica, ser. A, v. 102, pp. 49162.

Lindström, S., van de Schootbrugge, B., Dybkjæ, K., Pedersen, G.K., Fiebig, J., Nielsen, L.H., and Richoz, S., 2012, No causal link between terrestrial ecosystem change and methane release during the end-Triassic mass extinction: Geology, v. 40, pp. 531-534.

Lucas, S.G., Guex, J., Tanner, L.H., Taylor, D., Kürschner, W.M., Atudorei, V., and Bartolini, A., 2005, Definition of the Triassic-Jurassic boundary: Albertiana, v. 32, pp. 12-16.

Lucas, S.G. and Tanner, L.H., 2007, The nonmarine Triassic-Jurassic boundary in the Newark Supergroup of Eastern North America: Earth Science Reviews, v. 84, pp. 1-20.
Lucas, S.G., Taylor, D.G., Guex, J., Tanner, L.H., and Krainer, K., 2007, The proposed global stratotype section and point for the base of the Jurassic system in the New York Canyon Area, Nevada, USA: New Mexico Museum of Natural History and Science Bulletin, v. 40, pp. 139-168.

Mander, L., Kürschner, W.M., and McElwain, J.C., 2010, An explanation for conflicting records of the Triassic-Jurassic plant diversity: Proceedings of the National Academy of Sciences USA, v. 107, pp. 15351-15356.

Mander, L., Kürschner, W.M., and McElwain, J.C., 2013, Palynostratigraphy and vegetation history of the Triassic-Jurassic transition in East Greenland: Journal of the Geological Society. v. 170, pp. 37-46.

Marzoli, A., Bertrand, H., Knight, K.B., Cirilli, S., Buratti, N., Vérati, C., Nomade, C., Renne, P.R., Youbi, N., Martini, R., Allenbach, K., Neuwerth, R. Rapaille, C., Zaninetti, L., and Bellieni, G., 2004, Synchrony of the Central Atlantic Magmatic Province and the Triassic-Jurassic boundary climatic and biotic crisis: Geology, v. 32, pp. 973-976.

Marzoli, A., Bertrand, H., Chiaradia, M., Fontignie, D., Youbi, N., and Bellieni, G., 2006, The genesis of CAMP basalts (Morocco) from enriched lithosphere to late asthenosphere mantle sources: Geochimica et Cosmochimica Acta, v. 70, p. A396.

Marzoli, A., Bertrand, H., Knight, K.B., Cirilli, S., Nomade, S., Renne, P.R., Vérati, C., Youbi, N., Martini, R., and Bellieni, G., 2008, Comment on "Synchrony between the Central Atlantic Magmatic Province and the Triassic-Jurassic mass-extinction event? By Whiteside et al. (2007)": Palaeogeography, Palaeoclimatology, Palaeoecology, v. 262, pp. 189-193.

Marzoli, A., Jourdan, F., Puffer, J.H., Cuppone, T., Tanner, L.H., Weems, R.E., Bertrand, H., Cirilli, S., Bellieni, G., and De Min, A., 2011, Timing and duration of the Central Atlantic magmatic province in the Newark and Culpeper basins, eastern U.S.A: Lithos, v. 122, pp. 175-188.

Mazumder, M.A., 2013, Palaeoenvironmental changes of the Triassic-Jurassic boundary in the Restental section, Northern Calcareous Alps (Austria). Unpubl. MSc thesis at the Department of Geosciences, University of Oslo, pp. 30

McElwain, J.C., Beerling, D.J., and Woodward, F.I., 1999, Fossil plants and global warming at the Triassic-Jurassic boundary: Science, v. 285, pp. 1386-1390.

McElwain, J.C., Wagner, P.J., and Hesselbo, S.P., 2009, Fossil plant relative abundances indicate sudden loss of Late Triassic biodiversity in East Greenland: Science, v. 324, pp. 1554-1556.

McRoberts, C.A., Furrer, H., and Jones, D.S., 1997, Palaeoenvironmental interpretation of a Triassic-Jurassic boundary section from western Austria based on palaeoecological and geochemical data: Palaeogeography, Palaeoclimatology, Palaeoecology, v. 136, pp. 79-95.

McRoberts, C.A., Krystyn, L., and Hautmann, M., 2012, Macrofossil response to the end-Triassic mass extinction in the West-Tethyan Kössen Basin, Austria: Palaios, v. 27, pp. 607-616.

McRoberts, C.A., Ward, P.D., and Hesselbo, S., 2007. A proposal for the base Hettangian Stage (= base Jurassic System) GSSP at New York Canyon (Nevada, USA) using carbon isotopes. International Subcommission on Jurassic Stratigraphy Newsletter, v. 34, no. 1, pp. 43 49.

Mette, W., Elsler, A., and Korte, Ch., 2012, Palaeoenvironmental changes in the Late Triassic (Rhaetian) of the Northern Calcareous Alps: Clues from stable isotopes and microfossils: Palaeogeography, Palaeoclimatology, Palaeoecology, v. 350-352, pp. 62-72.

Mojsisovics, E.v., 1893, Die Cepholopoden der Hallstätter Kalke: Abhandlungen der kaiserlich-königlichen geologischen Reichsanstalt, v. $6 / 2, x+835 \mathrm{pp}$

Morante, R. and Hallam, A., 1996, Organic carbon isotopic record across the Triassic-Jurassic boundary in Austria and its bearing on the cause of the mass extinction: Geology, v. 24, pp. 391-394.

Morbey, S.J., 1975. The palynostratigraphy of the Rhaetian stage, Upper Triassic in the Kendelbachgraben, Austria: Palaeontographica B, v. 152, pp. 1-75.

Moser, M., 2008/09, Geofast 1 : 50 000, 118 Innsbruck, Geologische Bundesanstalt, Wien.

Mostler, H., Scheuring, B., and Urlichs, M., 1978, Zur Mega-, Mikrofauna 
und Mikroflora der Kössener Schichten (alpine Obertrias) vom Weißloferbach in Tirol unter besonderer Berücksichtigung der in der suessi- und marshi-Zone auftretenden Conodonten: Schriftenreihe der Erdwissenschaftlichen Kommision. Österreichische Akademie der Wissenschaften, v. 4, pp. 141-174.

Nomade, S., Knight, K.B., Beutel, E., Renne, P.R., Verati, C., Féraud, G., Marzoli, A., and Youbi, N., 2007, Chronology of the Central Atlantic Magmatic Province: Implications for the Central Atlantic rifting processes and the Triassic-Jurassic biotic crisis: Palaeogeography, Palaeoclimatology, Palaeoecology, v. 344, pp. 326-344.

Page, K.N., 2003, The Lower Jurassic of Europe: its subdivision and correlation: Geological Survey of Denmark and Greenland Bulletin, v. 1, pp. 23-59.

Page, K.N., Clémence, M.E. and Bloos, G., 2010, The Tilmanni Chronozone in NW Europe: Re-correlating the Base of the Jurassic System: Earth Science Frontiers, v. 17, special issue, pp. 8-9.

Pálfy, J., Demény, A., Haas, J., Hetényi, M., Orchard, M.J., and Vetö, I., 2001, Carbon isotope anomaly and other geochemical changes at the Triassic-Jurassic boundary from a marine section in Hungary: Geology, v. 29 , pp. 1047-1050.

Pálfy, J., Mortensen, J.K., Carter, E.S., Smith, P.L., Friedmann, R.M., and Tipper, H.W., 2000, Timing the end-Triassic mass extinction: First on land, then in the sea?: Geology, v. 28, pp. 39-42.

Pálfy, J. and Zajzon, N., 2012, Environmental changes across the TriassicJurassic boundary and coeval volcanism inferred from elemental geochemistry and mineralogy in the Kendlbachgraben section (Northern Calcareous Alps, Austria): Earth and Planetary Science Letters, v. 335336, pp. 121-134.

Payne, J.J. and Kump, L., 2007, Evidence for recurrent Early Triassic massive volcanism from quantitative interpretation of carbon isotope fluctuations: Earth and Planetary Science Letters, v. 256, pp. 264-277.

Pedersen, K.R. and Lund, J.J., 1980, Palynology of the plant-bearing Rhaetian to Hettangian Kap Stewart Formation, Scoresby Sound, East Greenland: Review of Palaeobotany and Palynology, v. 31, pp. 1-69.

Pieñkowski, G., Nied Ÿwiedzki, G., and Waksmunska, M., 2012, Sedimentological, palynological and geochemical studies of the terrestrial Triassic-Jurassic boundary in northwestern Poland: Geological Magazine, v. 149 , pp. 308-332.

Prinz, P., 1985, Stratigraphie und Ammonitenfauna der Pucara-Gruppe (Obertrias-Unterjura) von Nord-Peru: Palaeontographica, ser. A, v. 188, pp. 153-197.

Pueyo, E.L., Mauritsch, H.-J., Gawlick, H.-J., Scholger, R., and Frisch, W., 2007, New evidence for block and thrust sheet rotations in the central northern Calcareous Alps deduced from two pervasive remagnetisation events: Tectonics, v. 26, pp. 1965-1990.

Richardson, L., 1911, The Rhaetic and contiguous deposits of West, Middle, and of East Somerset: Quaterly Journal of the Geological Society of London, v. 67, pp. 1-74.

Rubinson, M. and Clayton, R.N., 1969, Carbon 13 fractionation between aragonite and calcite: Geochimica et Cosmochimica Acta, v. 33, pp. $997-$ 1002.

Ruhl, M., Bonis, N.R., Reichart, G.J., Sinninghe Damste, J.S., and Kürschner, W.M., 2011a, Atmospheric carbon injection linked to end-Triassic mass extinction: Science, v. 333, pp. 430-434.

Ruhl, M., Deenen, M.H.L., Abels, H.A., Bonis, N.R., Krijgsman, W., and Kürschner, W.M., 2010b, Astronomical constraints on the duration of the early Jurassic Hettangian stage and recovery rates following the endTriassic mass extinction (St. Audrie's Bay/ East Quantoxhead, UK): Earth and Planetary Science Letters, v. 295, pp. 262-276.

Ruhl, M., Kürschner, W.M., and Krystyn, L. 2009. Triassic-Jurassic organic carbon isotope stratigraphy of key sections in the western Tethys realm (Austria): Earth and Planetary Science Letters, v. 281, pp. 169-187.

Ruhl, M. and Kürschner, W.M., 2011, Multiple phases of carbon cycle disturbance from large igneous province formation at the Triassic-Jurassic transition: Geology, v. 39, pp. 431-434.

Ruhl, M., Veld, H., and Kürschner, W.M., 2010a, Sedimentary organic matter characterization of the Triassic-Jurassic boundary GSSP at Kuhjoch (Austria): Earth and Planetary Science Letters, v. 292, pp. 17-26.

Schaltegger, U., Guex, J., Bartolini, A., Schoene, B., and Ovtcharova, M., 2008, Precise U-Pb age constraints for end-Triassic mass extinction, its correlation to volcanism and Hettangian post-extinction recovery: Earth and Planetary Science Letters, v. 267, pp. 266-275.

Schobben, M.A.N., Bonis, N.R., Ruhl, M., and Kürschner, W.M., to be submitted, Palynostratigraphy and Carbon-Isotope stratigraphy of the Triassic Jurassic boundary at the GSSP Kuhjoch (Karwendel mountains, Austria): Lethaia.

Schoene, B., Crowley, J.L., Condon, D.J., Schmitz, M.D., and Bowring, S.A., 2006, Reassessing the uranium decay constants for geochronology using ID-TIMS U-B data: Geochimica et Cosmochimica Acta, v. 70, pp. 426445.

Schoene, B., Guex, J., Bartolini, A., Schaltegger, U., and Blackburn, T.J., 2010, Correlating the end-Triassic mass extinction and flood basalt volcanism at the 100 ka level: Geology, v. 38, pp. 387-390.

Schootbrugge, B. van de, Tremolada, F., Bailey, T.R., Rosenthal, Y., FeistBurkhardt, S., Brinkhuis, H., Pross, J., Kent, D.V., and Falkowski, P.G., 2007, End-Triassic calcification crisis and blooms of organic-walled disaster species: Palaeogeography, Palaeoclimatology, Palaeoecology, v. 244 , p. $126-141$

Schootbrugge, B. van de, Quan, T.M., Lindström, S., Püttmann, W., Heunisch, C., Pross, J., Fiebig, J., Petschik, R., Röhling, H.-G., Richoz, S., Rosenthal, Y., and Falkowski, P.G., 2009, Floral change across the Triassic/Jurassic boundary linked to flood basalt volcanism: Nature Geoscience, v. 2, pp. 589-594.

Schütz, S., 1974, Die Geologie der Karwendel-Mulde zwischen Dürrach und Baumgartenjoch (Nordtirol): Diploma Thesis, Technical University Berlin, Department of Geology and Palaeontologie: 160 p. (unpublished).

Schuurman, W.M.L., 1979, Aspects of Late Triassic palynology. 3. Palynology of Latest Triassic and Earliest Jurassic deposits of the Northern Limestone Alps in Austria and Southern Germany, with special reference to a palynological characterization of the Rhaetian stage in Europe: Review of Palaeobotany and Palynology, v. 27, pp. 53-75.

Seuss, B., Mapes, R.H., Klug, C., and Nützel, A., 2012, Exceptional cameral deposits in a sublethally injured Carboniferous orthoconic nautiloid from the Buckhorn Asphalt Lagerstätte in Oklahoma, USA: Acta Palaeontologica Polonica, v. 57, pp. 375-390.

Siblík, M., 1993, Lower Liassic brachiopods from SteinplatteKammerköhralm Area near Waidring (Northern Calcareous Alps, Salzburg): Jahrbuch der geologischen Bundesanstalt, v. 136, pp. 965982 .

Siblík, M., 1999, New data on the Hettangian brachiopod fauna of the Northern Calcareous Alps (Austria, Bavaria): Abhandlungen der geologischen Bundesanstalt, v. 56, pp. 419-438.

Suneby, L.B. and Hills, L.V., 1988, Palynological zonation of the Heiberg Formation (Triassic-Jurassic) eastern Sverdrup Basin, Arctic Canada: Bulletin of Canadian Petroleum Geologists, v. 36, pp. 347- 361.

Tomãsových, A., 2008, Composition and distribution of Hettangian brachiopod communities in the West Carpathians. Recovery after the end-Triassic mass extinction event: Fossils and Strata, v. 54, pp. 173181.

Tomãsových, A. and Siblík, M., 2007, Evaluating compositional turnover of brachiopod communities during the end-Triassic mass extinction (Northern Calcareous Alps): removal of dominant groups, recovery and community re-assembly: Palaeogeography, Palaeoclimatology, Palaeoecology, v. 44, pp. 170-200.

Tozer, E.T., 1979, Latest Triassic ammonoid faunas and biochronology, Western Canada: Current Research, Part B, Geological Survey of Canada, paper 79-1B, pp. 127-135.

Tozer, E.T., 1994, Canadian Triassic ammonoid faunas: Geological Survey of Canada Bulletin, v. 467, pp. 1-663.

Ulrich, R., 1960, Die Entwicklung der ostalpinen Juraformation im Vorkarwendel zwischen Mittenwald und Achensee: Geologica Bavarica, v. 41 , pp. $99-151$. 
Verati, C., Rapaille, C., Féraud, G., Marzoli, A., Bertrand, H., and Youbi, N., 2007, ${ }^{40} \mathrm{Ar} /{ }^{39} \mathrm{Ar}$ ages and duration of the Central Atlantic Magmatic Province volcanism in Morocco and Portugal and its relation to the Triassic-Jurassic boundary: Palaeogeography, Palaeoclimatology, Palaeoecology, v. 244, pp. 308-325.

Wähner,F., 1882-1898, Beiträge zur Kenntnis der tieferen Zonen des unteren Lias der nordöstlichen Alpen: Beiträge zur Paläontologie OesterreichUngarns, v. 2-11, pp. 1-291.

Ward, P.D., Garrison, G.H., Williford, K.H., Kring, D.A., Goodwin, D., Beattie, E.M.J., and McRoberts, Ch.A., 2007, The organ carbon isotopic and paleontological record across the Triassic-Jurassic boundary at the candidate GSSP section at Ferguson Hill, Muller Canyon, Nevada, USA: Palaeogeography, Palaeoclimatology, Palaeoecology, v. 244, pp. 281-289.

Warrington, G., 2005, The Charmouth 16A borehole, Dorset, U.K.: Palynology of the Penarth Group and the basal Lias Group (Upper Triassic-Lower Jurassic): Geoscience in south-west England, v. 11, pp. 109-116.

Warrington, G., Cope, J.C.W., and Ivimey-Cook, H.C., 1994, St. Audrie's Bay, Somerset, England: a candidate Global Stratotype Section and Point for the base of the Jurassic: Geological Magazine, v. 131, pp. 191-200.

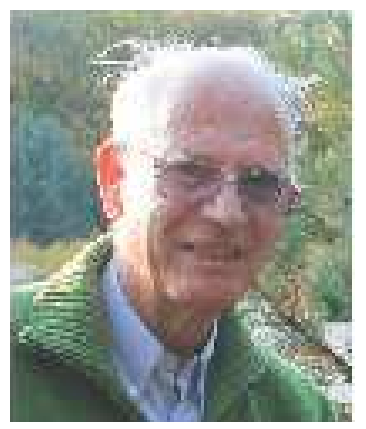

Axel von Hillebrandt is a retired Professor of the Technical University Berlin. He started his investigations with the study of foraminifers from the Palaeogene of the Northern Calcareous Alps and Spain. Later on his research activity was focused on the stratigraphy and mainly ammonites of the South American Jurassic. Since some years his research has concentrated on the T-J boundary of the NCA, mainly focused on the extinction and recovery of ammonites and foraminifers at this boundary. He was chairman of the German Subcommission of Jurassic Stratigraphy (1988-1995) and he is voting member of the SJS of ICS since 2004.

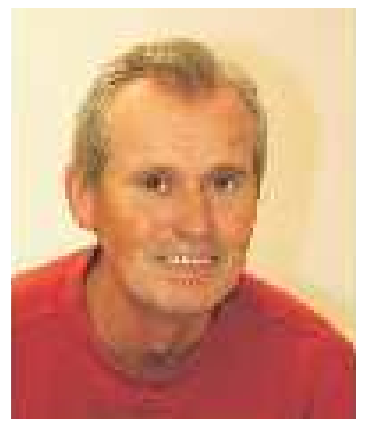

Leo Krystyn is a retired Professor of Palaeontology (University of Vienna) specialized in Triassic ammonoids, conodonts and pelagic bivalves with specific emphasis on the refinement of the Global Time Scale. Other research interests are the sequence stratigraphy and palaeo(bio)geography of the Triassic Tethys ocean as well as the sedimentary and geodynamic history of its margins. He is a Member of the Subcommission on Triassic Stratigraphy, Chairman of the Norian-Rhaetian boundary working group and Co-leader of the late IGCP project 467 "Triassic Time".
Wiedmann, J., 1970, Über den Ursprung der Neoammonoideen - Das Problem einer Typogenese: Ecologae geologicae Helvetiae, v. 63, pp. 923-1020.

Whiteside, J.H., Olsen, P.E., Kent, D.V., Fowell, S.J., and Et-Touhami, M., 2007, Synchrony between the Central Atlantic Magmatic Province and the Triassic-Jurassic mass-Extinction event?: Palaeogeography, Palaeoclimatology, Palaeoecology, v. 244, pp. 345-367.

Whiteside, J.H., Olsen, P.E., Kent, D.V., Fowell, S.J., and Et-Touhami, M., 2008, Synchrony between the Central Atlantic Magmatic Province and the Triassic-Jurassic mass-extinction event? Reply to Marzoli et al.: Palaeogeography, Palaeoclimatology, Palaeoecology, v. 262, pp. 194-198.

Whiteside, J.H., Olsen, P.E., Eglinton, T., Brookfield M.E., and Sambrotto, R.N., 2010, Compond-specific carbon isotopes from Earth's largest floot basalt eruptions directly linked to the end-Triassic mass extinction: PNAS.1001706107, pp. 1-5.

Yin, J., Smith, P.L.,Pàlfy, J., and Enay, R., 2007, Ammonoids and the Triassic/ Jurassic Boundary in the Himalayas of Southern Tibet: Palaeontology, v. 50, part 3, pp. 711-737.

Zajzon, N., Kristaly, F., Palfy, J., and Nemeth, A., 2012, Detailed clay mineralogy of the Triassic-Jurassic boundary section at Kendlbachgraben (Northern Calcareous Alps, Austria): Clay Minerals, v. 47, pp. 177-189.

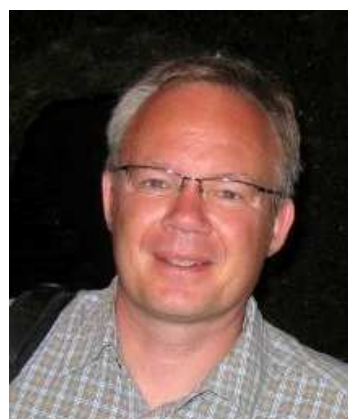

Wolfram Michael Kürschner is currently Professor at the Department of Geosciences and the Centre of Earth Evolution and Dynamics (CEED) of the University of Oslo (Norway). He previously worked as a lecturer/ researcher at Utrecht University (The Netherlands) where he received also his $\mathrm{PhD}$ degree. His interests include palaeobotany \& palynology, isotopegeochemistry and stratigraphy of marine and terrestrial deposits. He is voting member of the Subcomission on Triassic Stratigraphy of ICS since 2004. 